
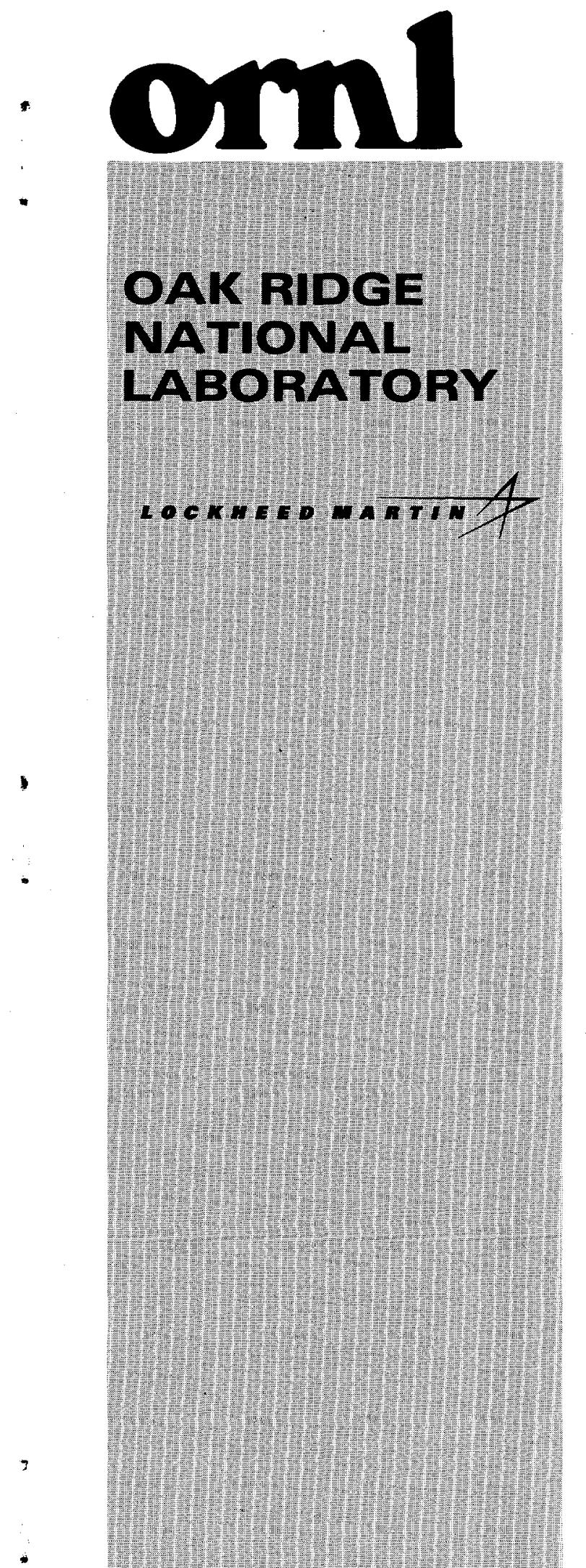

INANAGED AND OPERATED BY

LOCKHEED MARTIN ENEBCY RESEARCH CORPORATION FOR THE UNTIEOSTATES

DEPARTUEMT OF EIERGY
AFCFIVES

MAR 3 I 1999

ANVIRONMENTAL SCIENCES DIVISION O SPI

\section{A NATIONAL ASSESSMENT OF PROMISING AREAS FOR SWITCHGRASS, HYBRID POPLAR, OR WILLOW ENERGY CROP PRODUCTION}

\author{
Robin L. Graham \\ Marie E. Walsh
}

Environmental Sciences Division

Publication No. 4804

February 1999

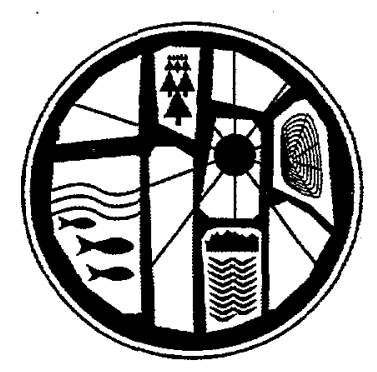


This report has been reproduced from the best available copy.

Reports are available to the public from the following source.

National Technical Information Service

5285 Port Royal Road

Springfield, VA 22161

Telephone 703-605-6000 (1-800-553-6847)

TDD 703-487-4639

Fax 703-605-6900

E-mail orders@ ntis.fedworld.gov

Web site http://www.ntis.gov/ordering.htm

Reports are available to U.S. Department of Energy (DOE) employees, DOE contractors, Energy Technology Data Exchange (ETDE) representatives, and International Nuclear Information System (INIS) representatives from the following source.

Office of Scientific and Technical Information

P.O. Box 62

Oak Ridge, TN 37831

Telephone 423-576-8401

Fax 423-576-5728

E-mail reports@adonis.osti.gov

Web site http://www.osti.gov/products/sources.html

Reports produced after January 1, 1996, are generally available via the DOE Information Bridge.

Web site http://unw.doe.gov/bridge 


\section{DISCLAIMER}

Portions of this document may be illegible in electronic image products. Images are produced from the best available original document. 


\title{
A NATIONAL ASSESSMENT OF PROMISING AREAS FOR SWITCHGRASS, HYBRID POPLAR, OR WILLOW ENERGY CROP PRODUCTION
}

\author{
Robin L. Graham and Marie E. Walsh \\ Bioenergy Feedstock Development Program \\ Environmental Sciences Division \\ Oak Ridge National Laboratory \\ Oak Ridge, TN 37831-6335 \\ Environmental Sciences Division \\ Publication No. 4804 \\ February 1999 \\ Prepared for the \\ Office of Transportation Technologies \\ and \\ Office of Utilities Technologies \\ U.S. Department of Energy
}

Prepared by the

OAK RIDGE NATIONAL LABORATORY

Oak Ridge, Tennessee 37831-6285

managed by

LOCKHEED MARTIN ENERGY RESEARCH CORP.

for the

U.S. DEPARTMENT OF ENERGY

under contract DE-AC05-96OR22464 



\section{CONTENTS}

Page

FIGURES $\ldots \ldots \ldots \ldots \ldots \ldots \ldots \ldots \ldots \ldots \ldots \ldots \ldots \ldots \ldots \ldots \ldots$

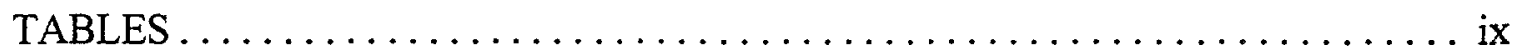

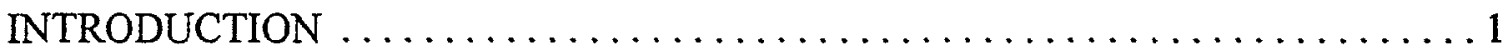

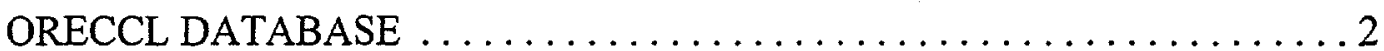

ORIBAS SWITCHGRASS ANALYSES OF 11 STATES $\ldots \ldots \ldots \ldots \ldots \ldots 3$

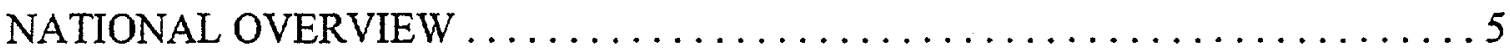

REGIONAL AND STATE ASSESSMENT $\ldots \ldots \ldots \ldots \ldots \ldots \ldots \ldots \ldots \ldots \ldots$

APPALACHIAN REGION $\ldots \ldots \ldots \ldots \ldots \ldots \ldots \ldots \ldots \ldots \ldots \ldots$

ORIBAS Switchgrass Analysis - Tennessee ............ 11

CORNBELT REGION . . . . . . . . . . . . . . . . . . . . . . . 15

ORIBAS Switchgrass Analysis - Missouri and Iowa . . . . . . . . 15

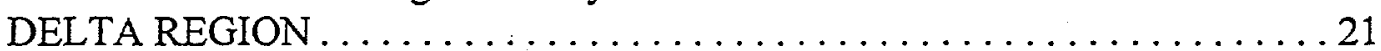

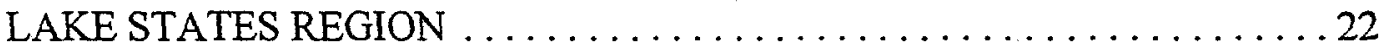

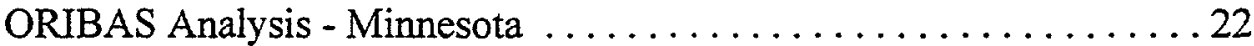

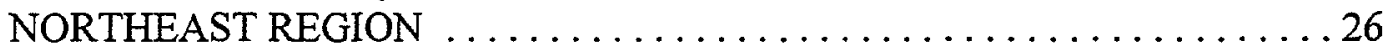

NORTHERN PLAINS REGION . . . . . . . . . . . . . . . 28

ORIBAS Analysis- Nebraska, North Dakota and South Dakota . . . . 28

PACIFIC NORTHWEST REGION (Hybrid Poplar Only) . . . . . . . . . . 36

SOUTHEAST REGION $\ldots \ldots \ldots \ldots \ldots \ldots \ldots \ldots \ldots \ldots \ldots \ldots \ldots \ldots \ldots \ldots$

ORIBAS Analysis - Alabama, Florida, Georgia, South Carolina . . . . 37

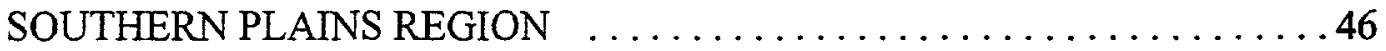

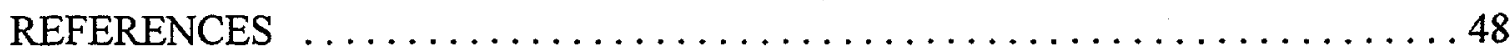





\section{FIGURES}

Page

1 Switchgrass farmgate prices (\$/dry ton) assuming median yields (as depicted in the ORECCL database) . . . . . . . . . . . . . . 6

2 Short Rotation Woody Crop farmgate prices ( $\$ /$ dry ton) assuming median yields (as depicted in the ORECCL database) $\ldots \ldots \ldots \ldots \ldots \ldots$

3 Estimated returns to land and management (\$/acre/year) based on cash rents for cropland and farmland value (as depicted in the

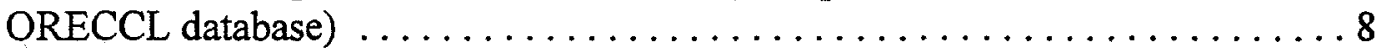

4 Cropland acreage suitable for switchgrass production (as depicted in the ORECCL database).

5 Appalachian Region

6 Location and marginal delivered switchgrass price of lowest cost 110,000 ton/yr facility sites in Tennessee

7 Location and marginal delivered switchgrass of lowest cost 700,000 ton $/ \mathrm{yr}$ facility sites in Tennessee. . . . . . . . . . . . . . 14

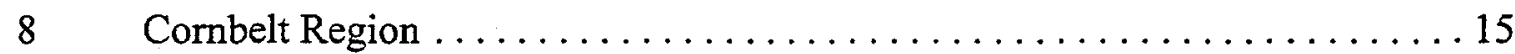

9 Location and marginal delivered switchgrass price of lowest cost

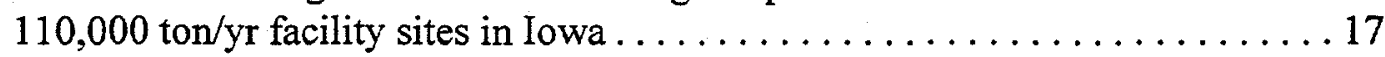

10 Location and marginal delivered switchgrass price of lowest cost

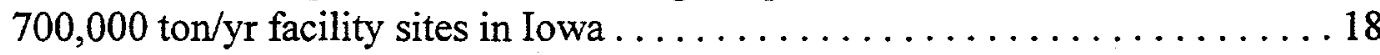

11 Location and marginal delivered switchgrass price of lowest cost 110,000 ton/yr facility sites in Missouri

12 Location and marginal delivered switchgrass price of lowest cost 700,000 ton/yr facility sites in Missouri

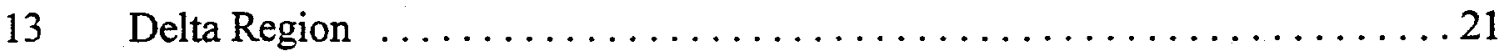


FIGURES (continued)

Page

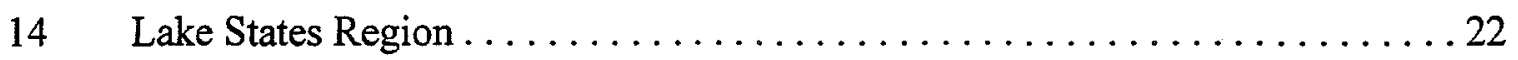

15 Location and marginal delivered switchgrass price of lowest cost

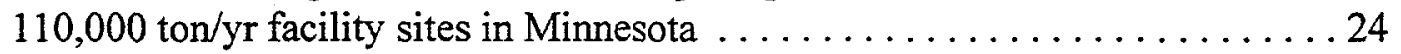

16 Location and marginal delivered switchgrass price of lowest cost 700,000 ton/yr facility sites in Minnesota. . . . . . . . . . . . . . 25

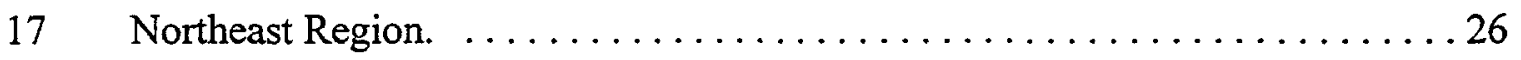

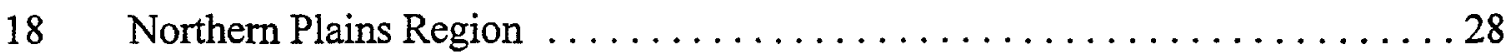

19 Location and marginal delivered switchgrass price of lowest cost 110,000 ton/yr facility sites in Nebraska . . . . . . . . . . . . . . 30

20 Location and marginal delivered switchgrass price of lowest cost 700,000 ton/yr facility sites in Nebraska . . . . . . . . . . . . . . 31

21 Location and marginal delivered switchgrass price of lowest cost 110,000 ton/yr facility sites in North Dakota . . . . . . . . . . . . . . 32

22 Location and marginal delivered switchgrass price of lowest cost 700,000 ton/yr facility sites in North Dakota ..................... 33

23 Location and marginal delivered switchgrass price of lowest cost 110,000 ton/yr facility sites in South Dakota .................... 34

24 Location and marginal delivered switchgrass price of lowest cost 700,000 ton/yr facility sites in South Dakota ...................... 35

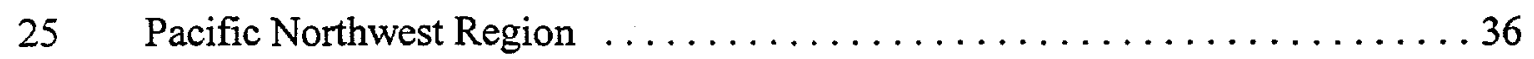

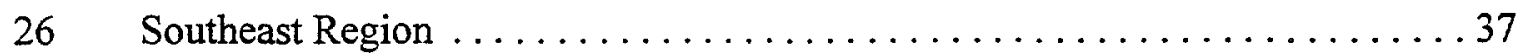

27 Location and marginal delivered switchgrass price of lowest cost

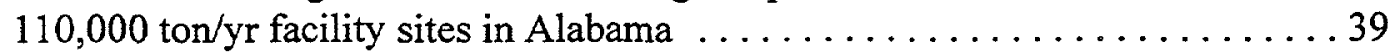




\section{FIGURES (continued)}

Page

28 Location and marginal delivered switchgrass price of lowest cost 700,000 ton/yr facility sites in Alabama $\ldots \ldots \ldots \ldots \ldots \ldots \ldots \ldots \ldots \ldots$

29 Location and marginal delivered switchgrass price of lowest cost 110,000 ton/yr facility sites in Florida

30 Location and marginal delivered switchgrass price of lowest cost $110,000 \mathrm{ton} / \mathrm{yr}$ facility sites in Georgia

31 Location and marginal delivered switchgrass price of lowest cost 700,000 ton/yr facility sites in Georgia

32 Location and marginal delivered switchgrass price of lowest cost 110,000 ton/yr facility sites in South Carolina .................... 44

33 Location and marginal delivered switchgrass price of lowest cost 700,000 ton/yr facility sites in South Carolina ................... 45

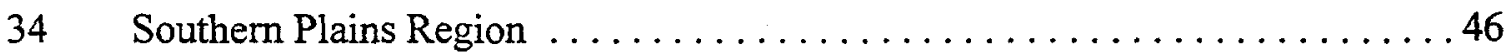





\section{TABLES}

\section{Page}

1 USDA regions and states included in ORIBAS switchgrass analyses. . . . . 10

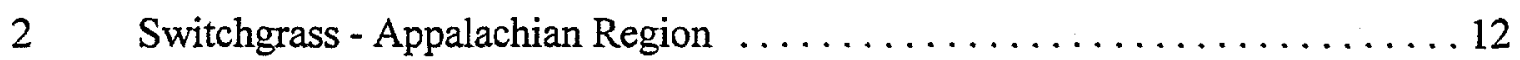

3 Short Rotation Woody Crops - Appalachian Region $\ldots \ldots \ldots \ldots \ldots \ldots$

$4 \quad$ Short Rotation Woody Crops - Cornbelt Region $\ldots \ldots \ldots \ldots \ldots \ldots \ldots$

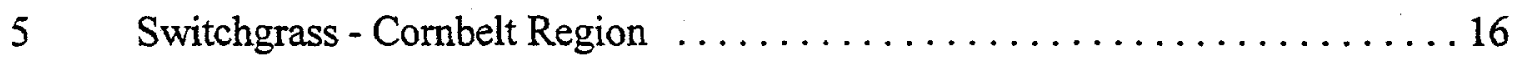

6 Short Rotation Woody Crops - Delta Region $\ldots \ldots \ldots \ldots \ldots \ldots \ldots \ldots$

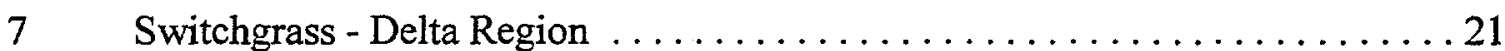

8 Short Rotation Woody Crops - Lake States Region $\ldots \ldots \ldots \ldots \ldots \ldots \ldots$

9 Switchgrass - Lake States Region $\ldots \ldots \ldots \ldots \ldots \ldots \ldots \ldots \ldots \ldots \ldots \ldots \ldots$

10 Short Rotation Woody Crops - Northeast Region $\ldots \ldots \ldots \ldots \ldots \ldots \ldots \ldots$

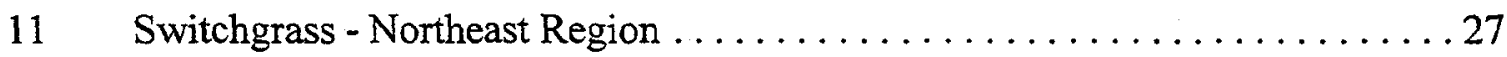

12 Short Rotation Woody Crops - Northern Plains Region . . . . . . . . . . . . . 29

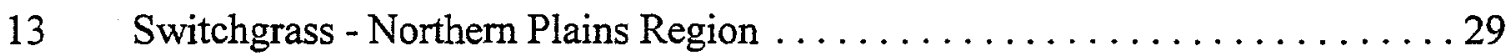

14 Short Rotation Woody Crops - Pacific Northwest Region $\ldots \ldots \ldots \ldots . \ldots 34$

15 Short Rotation Woody Crops - Southeast Region $\ldots \ldots \ldots \ldots \ldots \ldots \ldots$

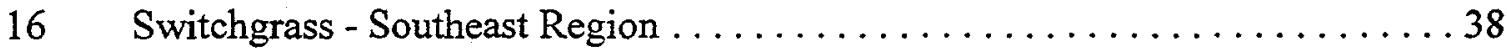

17 Short Rotation Woody Crops - Southern Plains Region $\ldots \ldots \ldots \ldots \ldots . \ldots 4$

18 Switchgrass - Southern Plains Region $\ldots \ldots \ldots \ldots \ldots \ldots \ldots \ldots \ldots \ldots$ 


\section{INTRODUCTION}

The objective of this paper is to systematically assess the cropland acreage that could support energy crops and the expected farmgate and delivered prices of energy crops. The assessment is based on output from two modeling approaches: (1) the Oak Ridge County-Level Energy Crop (ORECCL) database (1996 version) and (2) the Oak Ridge Integrated Bioenergy Analysis System (ORIBAS). The former provides countylevel estimates of suitable acres, yields, and farmgate prices of energy crops (switchgrass, hybrid poplar, willow) for all fifty states. The latter estimates delivered feedstock prices and quantities within a state at a fine resolution $\left(1 \mathrm{~km}^{2}\right)$ and considers the interplay between transportation costs, farmgate prices, cropland density, and facility demand. It can be used to look at any type of feedstock given the appropriate input parameters. For the purposes of this assessment, ORIBAS has been used to estimate farmgate and delivered switchgrass prices in 11 states (AL, FL, GA, IA, MN, MO, ND, NE, SC, SD, and $T N$ ). Because the potential for energy crop production can be considered from several perspectives, and is evolving as policies, economics and our basic understanding of energy crop yields and production costs change, this assessment should be viewed as a snapshot in time.

Both modeling approaches are based on current cropland use patterns (1992 Agricultural Census) and recent (1996) estimates of likely energy crop yields in the year 2000. Only acreage that is currently supporting crop production is considered-land that could produce crops but is currently used as pasture is excluded. Set-aside lands are included in the landbase to the extent that USDA has classified them as cropland. Both modeling approaches (ORECCL and ORIBAS) calculate farmgate prices of energy crops-ORECCL calculates the price as the net present value (NPV) price over the entire energy crop production cycle that provides a return to the farmer that is comparable to the NPV county cash rent for the same time frame, while ORIBAS calculates the NPV price that is comparable to the NPV of the expected-profit from growing the current mix of conventional crops in the area over the same production cycle. The crop production cycle is assumed to be 10 years for switchgrass, 7 years for poplar, and 22 years for willow.

Prices are based on all production practices needed to supply switchgrass bales stacked at the side of the road or wood chips contained in a van waiting at the side of the road. All prices are in 1993 dollars. The ORECCL analysis does not evaluate transportation costs, but ORIBAS estimates transportation costs from production site to a user facility for two levels of switchgrass demand (110,000 and 700,000 dry tons/year).

The two modeling approaches are useful in identifying the U.S. regions where energy crops can be grown at the lowest price and in estimating a reasonable expected price for energy crops for any given area of the country. However, interpretation of the results should consider two important caveats. First the methods used in the analyses contain no feedback mechanisms to reflect the change in conventional crop (e.g., corn, soybean) prices that would result as increasing acres were diverted to energy crop production. Thus, as the cumulative number of energy crop acres increase, the analysis 
would increasingly underestimate the price that would need to be offered for energy crops to maintain the same profit as conventional crop production. Second, the analyses estimate only the acres for which the estimated break-even energy crop price provides at least the same profit as conventional crops given the yield and production cost assumptions. It says nothing about how many acres of energy crops would actually be planted at that price. Thus, while the assessments may indicate that 40 million acres could produce energy crops if a market existed that would pay $\$ 35 / \mathrm{dt}$, this should not be interpreted to mean that 40 million acres of energy crops will be produced and sold at $\$ 35 /$ dt. An analytical approach that does consider price-supply interactions between conventional agricultural crops and energy crops is under development (De La Torre Ugarte and Ray 1998).

The review begins with a brief discussion of the two analytical approaches (ORECCL and ORIBAS) used to assess energy crop potential. Next, the results from each approach are compared and contrasted. Results on a national level are presented first, followed by regional and state results.

\section{ORECCL DATABASE}

The Oak Ridge Energy Crop County-Level (ORECCL) database describes the likely yields of energy crops (switchgrass and short rotation woody crops) at a countylevel (Graham et al 1996a, 1997b). In the 1996 version of ORECCL, only two short rotation woody crops are considered-hybrid poplar and willow. Furthermore, a county is assumed suitable for either hybrid poplar or willow production but not both. Thus, the short rotation woody crop data given for a county assume one or the other woody crop. Switchgrass is the only herbaceous energy crop considered in ORECCL. The energy crop yields are based on expert opinion as of 1996 and represent the yield that might be expected using best management practices circa the year 2000 on existing cropland. ${ }^{1}$ In some regions, with some crops such as the Northeast and switchgrass, the ORECCL yield values are mostly educated conjecture as there were few to no field data. The same can be said for switchgrass yields in the Northern Plains and Lake States and willow yields in the Lake States. The farmgate prices for switchgrass and hybrid poplar are based on the BIOCOST (version 1) production model and BIOCOST's default

\footnotetext{
In November of 1997, energy crop yields and the energy crop landbase in the 1996 ORRECL database were readdressed in a workshop with energy crop researchers. Some yields were changed though none drastically. The most noticeable change was that switchgrass yields were reduced in the far west and the geographic variation of yields of all species was increased. Likewise some changes were made in defining the landbase but again not in a major way except for willow whose range was extended considerably southwards and made to overlap with the poplar range. At the same workshop, energy crop production approaches (e.g., amount of fertilizer etc) were also addressed and some changes in production were also made. Again the changes were not major although willow production costs will rise more than poplar or switchgrass. The production changes have not yet been fully incorporated into BIOCOST. Once BIOCOST is updated, ORECCL farmgate prices will be updated using the new yields, new BIOCOST and more recent cropland cash rent estimates. These updates will in general increase energy crop prices but fairly uniformly across the country so the spatial pattern of prices are likely to stay the same. And thus the general conclusions on energy crop potential derived from 1996 version of ORECCL will most likely not alter.
} 
assumptions with two exceptions (Walsh and Becker 1996). First, 1993 rather than 1995 prices for equipment and fuels were used. Second, the expected returns to land and management used in the farmgate price calculations are not BIOCOST's multi-state regional default values. Rather they are county-level values created using the following equation.

\begin{abstract}
County-level Returns $(\$ / a c r e / y r)=1993$ state cropland cash rent * (county farmland value/state farmland value)
\end{abstract}

This approach assumes that cropland cash rent is a good surrogate for expected returns to land and management and that farmland value is controlled by the potential profitability of the cropland; therefore, geographic differences in farmland value can be used to infer geographic differences in likely returns to cropland. The approach has the drawback that factors other than profit expected from farming can influence farmland value (e.g., potential for residential development). Thus the ORECCL values for returns to cropland are inflated in counties and states with significant development pressures. For example, DuPage County just west of Chicago has very high county-level returns in ORECCL and thus very high farmgate energy crop prices. Fortunately such counties usually have very little cropland and, therefore are, comparatively insignificant from a larger perspective.

The production costs (other than returns to land and management which are the same as for hybrid poplar and switchgrass calculations) used in calculating the farmgate prices for willow are based on an unpublished version of BIOCOST adapted to willow (Walsh and Becker, personal communication, 1996). ${ }^{2}$. Again the costs are in 1993 dollars.

\title{
ORIBAS SWITCHGRASS ANALYSES OF 11 STATES
}

ORIBAS is a GIS-based modeling system for predicting delivered feedstock costs across a state (Graham et al. 1996b, 1997a, Noon et al. 1996). ORIBAS relies on $1 \mathrm{~km}^{2}$ resolution maps of land use to spatially distribute potential energy crop supplies and road network maps to estimate transport costs. The system can compute farmgate prices and potential supplies endogenously, or these can be input to the system. If farmgate prices and supplies are calculated endogenously then the system requires information on conventional crop yields, prices, and production costs in addition to information on the energy crop yields and production costs. In its most complicated mode of calculation, the system also considers soil quality impacts on yields using the USDA model EPIC. ${ }^{3}$

In the set of ORIBAS analyses of switchgrass production considered in this paper, farmgate prices and supplies were calculated endogenously and took into consideration soil impact on yield. These ORIBAS analyses also relied on the BIOCOST model energy crop.

${ }^{2} \mathrm{~A}$ revised version of BIOCOST based on the 1997 energy crop workshop will contain willow as a third

${ }^{3} \mathrm{EPIC}$ is a USDA model for predicting crop production and erosion characteristics (Williams et al 1989). 
(version 1) for estimating switchgrass production costs (in 1993 dollars) other than returns to land and management. The endogenous calculation of farmgate prices and supplies did not consider the interactions between supply and price of conventional and energy crops.

The main difference between ORIBAS analyses and ORECCL in the estimation of farmgate prices is that the ORIBAS analyses did not use published cash rent and farmland values to infer expected returns from cropland. Rather, the ORIBAS analyses directly calculated expected returns from land and management on the basis of the predicted profitability of the major crops grown on the different soils within a county. Thus the ORIBAS returns were not influenced by development pressures on farmland value. Consequently the ORIBAS estimates of return to land and management are generally lower than those of ORECCL, and, thus, the ORIBAS-predicted farmgate prices are also lower. State-level differences in ORIBAS and ORRECL farmgate prices are given in the tables following each regional discussion in the paper.

ORIBAS predicts the number and location of bioenergy facilities (and their marginal delivered price for feedstock) that could be supported within a state given $a$ priori assumptions about cropland availability and facility feedstock demand. In the ORIBAS analyses used for this review, two facility demand levels were examined-110,000 dry tons/year and 700,000 dry tons/year. Cropland available for switchgrass production was defined as the fraction of cropland within a county currently planted to the most dominant conventional crop. (Total cropland suitable for energy crop production in a county was based on the ORRECL value for that county.) In most cases, using this dominant crop strategy to define availability meant 40 to $60 \%$ of the ORECCL value for potential cropland in a county was allowed to produce switchgrass.

The ORIBAS algorithm for predicting facility sites and feedstock prices locates each facility one at a time, minimizing the marginal delivered price for feedstock until all the land designated in the state as available for switchgrass production has been used to supply plants. The location and the marginal-delivered price of switchgrass for each facility is a function of the predicted farmgate prices for switchgrass produced in the vicinity of the facility and the transport costs associated with moving that switchgrass to the facility. Per-ton transport costs are calculated on the basis of travel distance and travel time. The ORIBAS algorithm for siting plants first calculates the potential farmgate price and supply of switchgrass (based on yield) that could be produced on all land considered available for switchgrass. ORIBAS then calculates the costs of transporting that switchgrass to any location in the state. ORIBAS then determines the location in the state that could be supplied with 110,000 or 700,000 dry tons at the lowest cost. That location becomes the site of the first facility and the land (e.g., switchgrass supplies) used to support that facility is withdrawn from further consideration. ORIBAS then repeats those two steps to predict the next lowest cost facility location. This process is repeated until all the available land (i.e., supplies) in the state is being used to supply facilities. For this review, only the lowest cost $50 \%$ of the facilities are mapped and discussed. (That is, the facilities were ranked from lowest to highest cost and those facilities falling on the low half of the list are considered.) This set of facilities, if built, would utilize about $25 \%$ of the cropland in the state. Constraining land availability and 
only considering the "best facilities" is an inexact way of recognizing that cropland will be utilized for multiple crops and that if large acreages went into switchgrass production, other crop prices would change and thus the model's prediction would become irrelevant.

The ORIBAS analysis of farmgate and delivered prices in selected states complements the ORECCL analysis. The ORECCL estimates of farmgate price are more extensive and more tied to actual land costs; however, ORIBAS attempts to account for finer scale geographic differences in energy crop yields and land value. Furthermore, ORIBAS provides estimates of delivered price, while ORECCL does not.

\section{NATIONAL OVERVIEW}

Two major trends are evident from a national perspective. First, in the near term (yr 2000 yields), switchgrass is a lower cost feedstock than either hybrid poplar or willow in all regions except the Northeast where willow feedstock is competitive with switchgrass ${ }^{4}$ (Figs. 1 and 2). ${ }^{5}$ The cost difference is on the order of $\$ 10$ to $\$ 20$ per ton. This is because switchgrass yields are expected to be slightly higher and its production costs are lower. It should be noted that this cost difference is probably exaggerated because a single rotation length was assumed for hybrid poplar. This tends to artificially raise prices in areas with low hybrid poplar yields. From an economic standpoint low yields should be associated with longer rotations so the cost of harvest, which is fairly constant on a per acre basis, can be better distributed.

Second, the Southeast, Delta, Appalachian, Southern Plains and the most northerly Northern Plains states have the lowest-cost farmgate prices, and they are for switchgrass. If the ORECCL yields of 4 to 5 dry tons of switchgrass can be achieved routinely in these regions, then significant acreages ( 40 million acres) should be able to support switchgrass production at a farmgate price of under $\$ 35 /$ dry ton and still offer the farmer a return to lands and management comparable or better than those of conventional crops (Figs. 3 and 4). Whether such yields can be routinely achieved in the Plains states is very uncertain however due to the lack of field data (in the North) and fairly large year to year climatic variation across the region as a whole. Such yields (and better) have been routinely achieved in research plots in the South (Alabama, Tennessee, Virginia), where climatic variability is less.

\footnotetext{
${ }^{4}$ Future assessments using revised willow production costs will probably not show willow as cost competitive with switchgrass even in the northeast.
}

${ }^{5}$ Figs. 1-4 are derived directly from the ORECCL database and contain no data from the ORIBAS analyses. 

Breakeven Price - Switchgrass
Median Yield

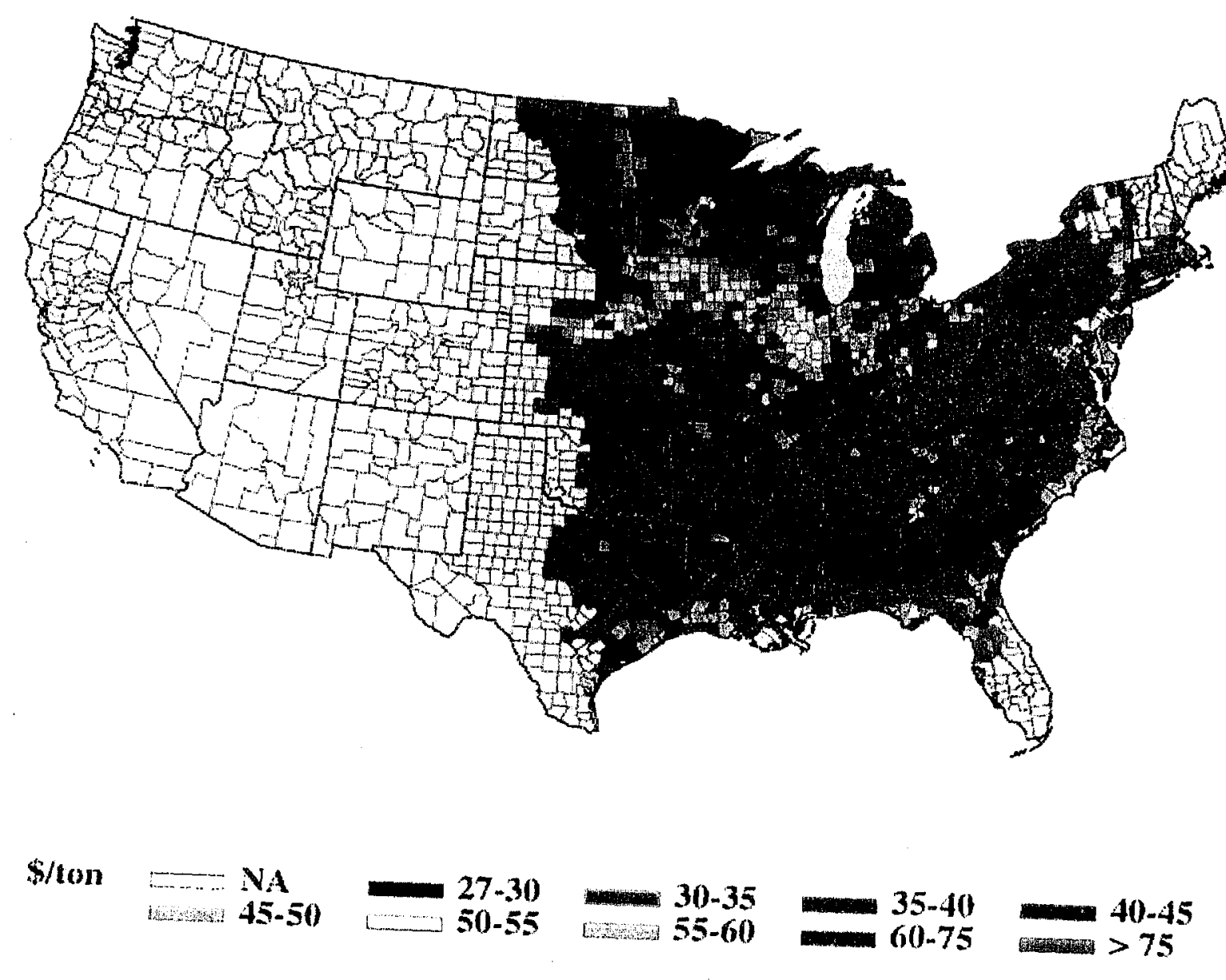

Fig. 1. Switchgrass farmgate prices (\$/dry ton) assuming median yields (as depicted in the ORECCL database). 
Breakeven Price - SRWC

Median Yield
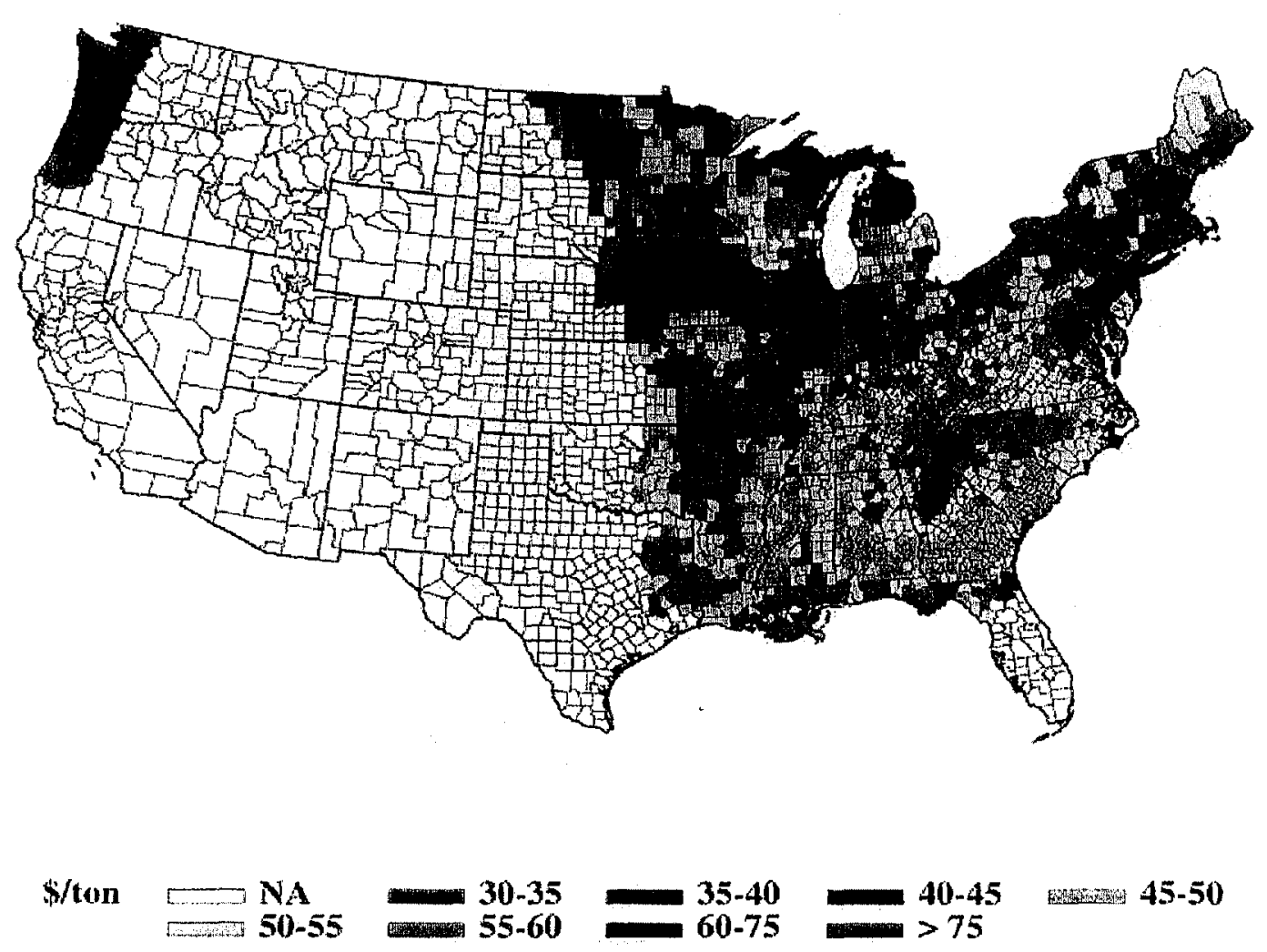

Fig. 2. Short Rotation Woody Crop farmgate prices (\$/dry ton) assuming median yields (as depicted in the ORECCL database). 

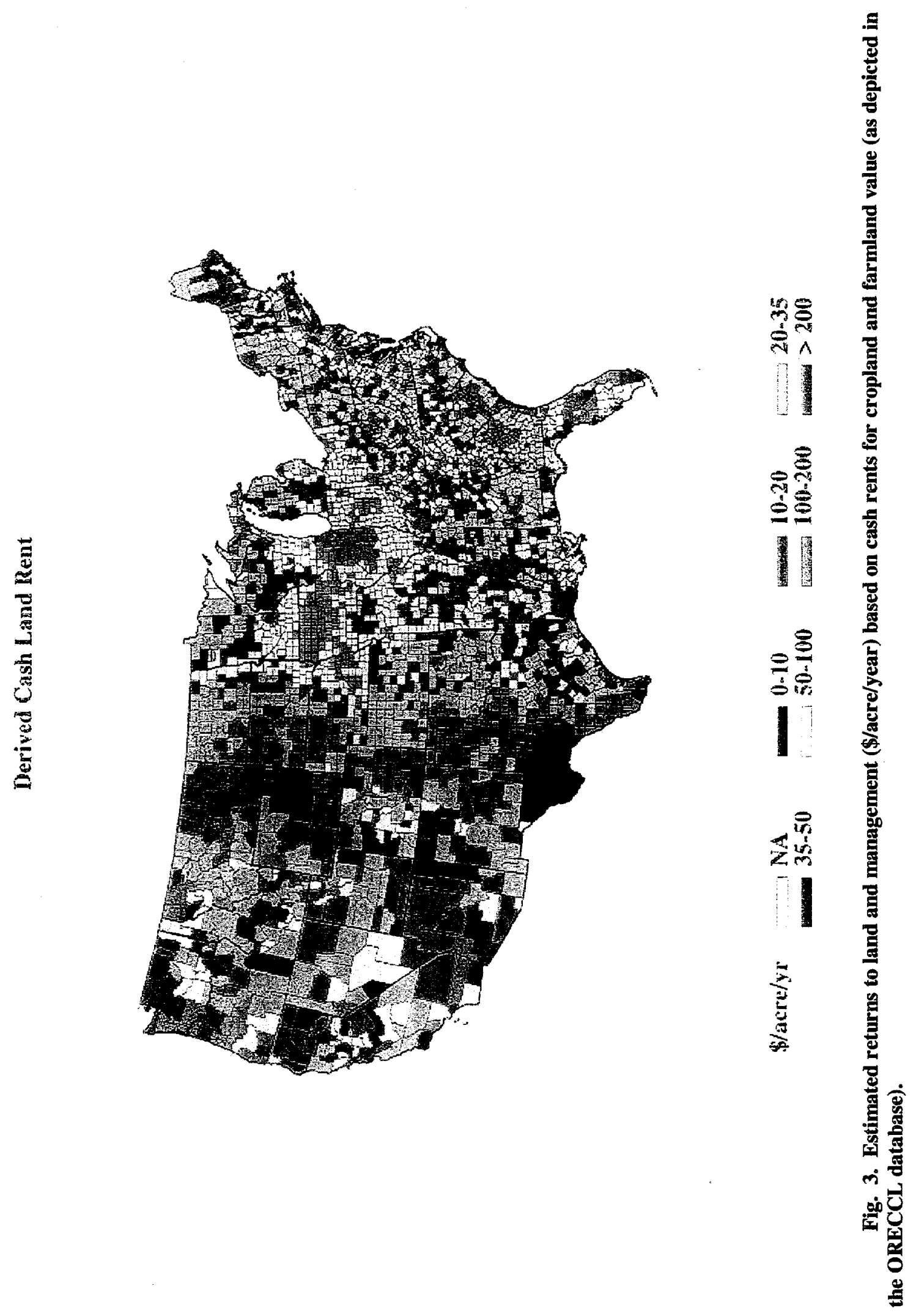
焉

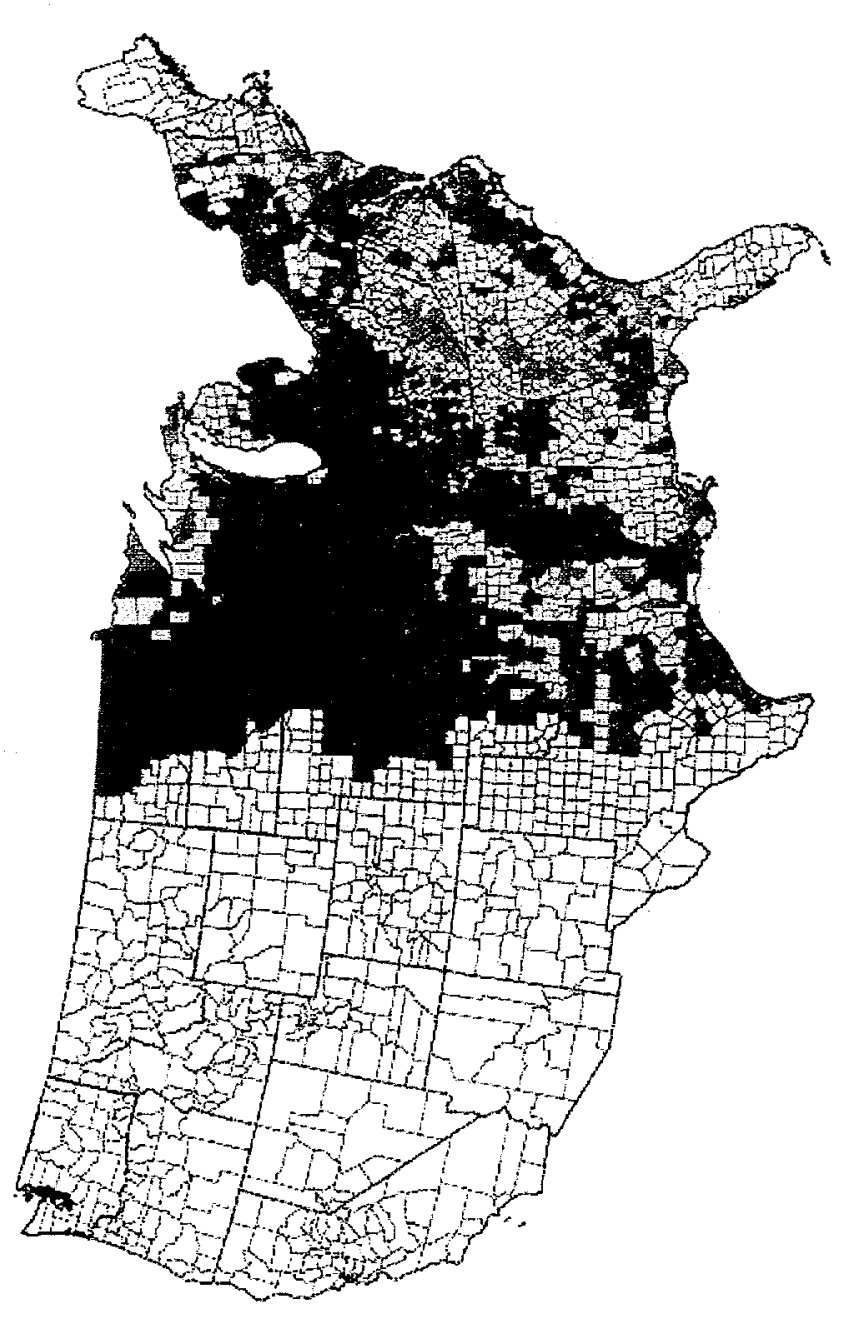

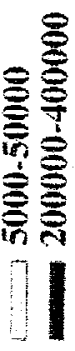

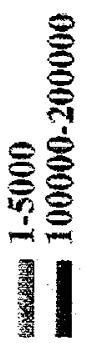

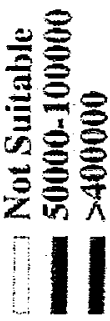

$\stackrel{5}{2}$ 
The ORIBAS analyses show broad ranges $(>\$ 10)$ for delivered switchgrass marginal prices in the central Midwest (IA, MN, MO, and NE) and narrow ranges ( $\$ 5)$ in the southern states and the Dakotas. The distribution of delivered prices for those states with broad ranges are quite skewed with most facilities at the higher switchgrass price end. The states with narrower ranges also had a more even distribution of prices. Tennessee was the only state for which the geographic distribution of the small switchgrass demand facilities was different from that of the large demand facilities.

\section{REGIONAL AND STATE ASSESSMENT}

A written summary and two tables of ORECCL and ORIBAS-based information on energy crop prices and potential acreages are presented for each USDA region capable of producing switchgrass, hybrid poplar, or willow. The definition of the regions is shown in Table 1. The Mountain region (AZ, CO, ID, MT, NM, NV, UT, WY) is not presented, as switchgrass, willow, or hybrid poplar production on any large scale is not possible in this region without irrigation. California is also not represented for the same reason.

Table 1. USDA regions and states included in ORIBAS switchgrass analyses

\begin{tabular}{|l|l|l|}
\hline \multicolumn{1}{|c|}{ USDA Region } & \multicolumn{1}{|c|}{ States included in region } & \multicolumn{1}{c|}{ States with ORIBAS switchgrass analyses } \\
\hline \hline Appalachian & KY, NC, VA, W, TN & TN \\
\hline Cornbelt & $\mathrm{L}, \mathrm{N}, \mathrm{IA}, \mathrm{MO}, \mathrm{OH}$ & IA, MO \\
\hline Delta & $\mathrm{AR}, \mathrm{LA}, \mathrm{MS}$ & none \\
\hline Lake States & MI, MN, WI & MN \\
\hline Northeast & $\mathrm{CN}, \mathrm{DE}, \mathrm{ME}, \mathrm{MD}, \mathrm{MA}, \mathrm{NH}, \mathrm{NJ}, \mathrm{NY}, \mathrm{PA}, \mathrm{RI}, \mathrm{VT}$ & none \\
\hline Northern Plains & $\mathrm{KS}, \mathrm{NE}, \mathrm{ND}, \mathrm{SD}$ & NE, ND, SD \\
\hline Pacific Northwest & $\mathrm{OR}, \mathrm{WA}$ & none \\
\hline Southeast & $\mathrm{AL}, \mathrm{FL}, \mathrm{GA}, \mathrm{SC}$ & AL, FL, GA, SC \\
\hline Southern Plains & $\mathrm{OK}, \mathrm{TX}$ & none \\
\hline
\end{tabular}

Two facility site maps are presented (110,000 dry ton/yr size and 700,000 dry/yr) for each state analyzed with ORIBAS for switchgrass production. These maps show where facilities might be located if feedstock cost was the sole criterion for siting. The facilities are categorized, based on their marginal delivered price, into four groups of equal number of facilities. As noted before, only the lowest cost $50 \%$ of the facilities sited by the ORIBAS algorithm were mapped. The state descriptions refer only to the mapped sites. 
The number of potential facilities on each map is a function of the acreage of cropland suitable for switchgrass production and the demand level of the facility; thus, South Carolina, which has little cropland, has very few facilities, while Iowa has hundreds; and in each state there are only $1 / 7$ th as many $700,000 \mathrm{dry}$ ton/yr facilities as 110,000 dry/yr facilities.

\section{APPALACHIAN REGION}

Most of the rural counties in this region (Fig. 5) have estimated farmgate switchgrass prices between $\$ 30$ and $\$ 35 /$ dry ton (Table 2). Promising areas include the upper coastal plain of North Carolina, western Kentucky and western Tennessee, and the area south of Nashville near the Duck River (Fig. 1). These states would also support hybrid poplar at comparatively low prices provided yields of 5 dry tons are achievable on a routine basis (Table 3). The western half of Tennessee and Kentucky appear most promising for hybrid poplar with farmgate prices mostly in the $\$ 48$ to $\$ 52 /$ dry ton range (Fig. 2).

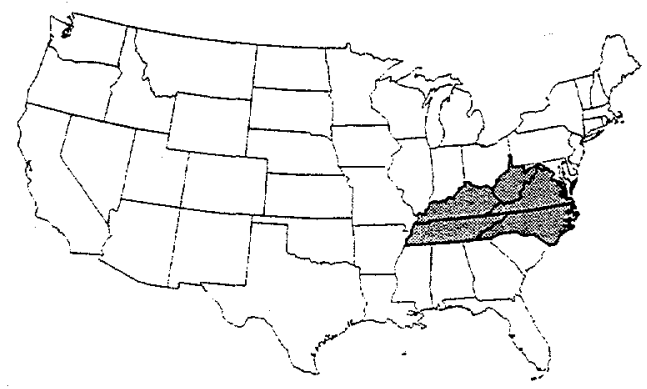

Fig. 5. Appalachian Region

\section{ORIBAS Switchgrass Analysis - Tennessee}

Tennessee switchgrass farmgate prices are estimated to be between $\$ 25$ and $\$ 30 /$ dry ton for virtually all of the eastern two-thirds of the state. This is due to the very low calculated returns to conventional crop production. In many cases these were estimated to be under $\$ 10 /$ acre/year. In the western third of the state, which has a much higher density of cropland and better soils, farmgate prices were estimated to be $\$ 30$ to $35 / \mathrm{dry}$ ton, and the calculated returns to conventional crop production were comparable to the cash rent estimates in ORECCL. The pattern of density of cropland versus farmgate prices is such that the delivered price of switchgrass is fairly uniform across the states; transport costs are lower where farmgate prices are higher and vice versa. 
Table 2. Switchgrass - Appalachian Region

\begin{tabular}{|c|c|c|c|c|c|c|c|c|c|c|c|c|}
\hline SWG & $\begin{array}{l}\text { Average } \\
\text { vield } \\
\text { tronacerelyrt }\end{array}$ & $\begin{array}{c}\text { ORECCL } \\
\text { Average } \\
\text { farmgate } \\
\text { price } \\
\text { (siton) } \\
\end{array}$ & $\begin{array}{c}\text { Acreage of } \\
\text { cropland } \\
\text { suitabla for } \\
\text { SWG } \\
(000) \\
\end{array}$ & $\begin{array}{c}\text { ORECCL } \\
\text { Acresge of } \\
\text { land with } \\
\text { tarmgate } \\
\text { price }<\$ 30 \\
\text { (000) } \\
\end{array}$ & $\begin{array}{l}\text { ORECCL } \\
\text { Acreage of } \\
\text { land with } \\
\text { farmgate } \\
\text { price }<\$ 35 \\
\text { (D00) }\end{array}$ & $\begin{array}{c}\text { ORECCL } \\
\text { Acreage of } \\
\text { land with } \\
\text { farmgare } \\
\text { price < <40 } \\
\text { OOCOO } \\
\end{array}$ & $\begin{array}{c}\text { ORECCL } \\
\text { Acreage of } \\
\text { land with } \\
\text { farmgate } \\
\text { price }<\$ 45 \\
\text { (000) } \\
\end{array}$ & $\begin{array}{l}\text { ORECCL } \\
\text { Average } \\
\text { cash rent } \\
\text { \$lacrelyr) } \\
\end{array}$ & $\begin{array}{c}\text { Number } \\
\text { of } \\
\text { counties }\end{array}$ & $\begin{array}{c}\text { apuBaS } \\
\text { Average land } \\
\text { rent } \\
\text { \$lacrelyy } \\
\end{array}$ & $\begin{array}{c}\text { ORiBAS } \\
\text { Average } \\
\text { farmgate } \\
\text { price } \\
\text { stion } \\
\end{array}$ & $\begin{array}{l}\text { Farngate } \\
\text { price } \\
\text { difference } \\
\text { ORIBAS- } \\
\text { ORECCL } \\
\end{array}$ \\
\hline Kentucky & 6.44 & $\$ 35.91$ & 5,417 & 57 & 2,482 & 4,710 & 5.249 & $\$ 55,62$ & 120 & & & \\
\hline Nosth Carolina & 5.11 & $\$ 38.30$ & 4,668 & 21 & 2,626 & 3,046 & 3,361 & $\$ 38,36$ & 100 & & & \\
\hline Tennessee & 6.25 & $\$ 34.89$ & 4,458 & 45 & 2,978 & 4,043 & 4,323 & $\$ 48,13$ & 95 & $\$ 19.52$ & $\$ 24.75$ & (\$10.14) \\
\hline Virginia & 5.63 & $\$ 35.18$ & 2,727 & 694 & 1,776 & 2,170 & 2,321 & $\$ 35.58$ & 96 & & & \\
\hline \multirow[t]{2}{*}{ West Virginia } & 6.23 & $\$ 32.57$ & 616 & 194 & 522 & 551 & 577 & $\$ 34.99$ & 55 & & & \\
\hline & & $\$ 36.05$ & 17,888 & 1,011 & 10,384 & 14,520 & 15,831 & $\$ 45.48$ & 466 & & & \\
\hline & & & & & & & & & & & & \\
\hline
\end{tabular}

Table 3. Short Rotation Woody Crop - Appalachian Region

\begin{tabular}{|c|c|c|c|c|c|c|c|c|c|}
\hline SRWC & $\begin{array}{c}\text { Average } \\
\text { rialé } \\
\text { (tonfacre/vi) }\end{array}$ & $\begin{array}{c}\text { OAfECCL } \\
\text { Averafe } \\
\text { tarmgate } \\
\text { price } \\
\text { (\$lton) } \\
\end{array}$ & $\begin{array}{l}\text { Acreage of } \\
\text { cropland } \\
\text { suitabie for } \\
\text { SRWC } \\
\text { (000) }\end{array}$ & $\begin{array}{c}\text { ORECCLL } \\
\text { Acreage of } \\
\text { land with } \\
\text { farmgate } \\
\text { price }<\$ 35 \\
\text { (000) } \\
\end{array}$ & $\begin{array}{c}\text { ORECCL } \\
\text { Acreage of } \\
\text { land with } \\
\text { farmagate } \\
\text { price }<\$ 40 \\
\text { (000) }\end{array}$ & $\begin{array}{l}\text { ORECCA } \\
\text { Acreage of } \\
\text { land with } \\
\text { farmgate } \\
\text { price }<\$ 45 \\
(000)\end{array}$ & $\begin{array}{l}\text { ORECCLL } \\
\text { Acreage of } \\
\text { land with } \\
\text { farmgate } \\
\text { price }<\$ 50 \\
\text { (000) }\end{array}$ & $\begin{array}{l}\text { ORECCL } \\
\text { Average } \\
\text { cash rent } \\
\text { Slacreiyn) } \\
\end{array}$ & $\begin{array}{l}\text { Number } \\
\text { of } \\
\text { counties }\end{array}$ \\
\hline Kentucky & 4.94 & $\$ 53.79$ & 5,417 & 0 & 0 & 0 & 1,162 & $\$ 55.62$ & 120 \\
\hline North Carolins & 4.34 & $\$ 54.77$ & 4,468 & 0 & 0 & 0 & 454 & $\$ 38.36$ & 100 \\
\hline Tennessee & 4.85 & $\$ 52.99$ & 4,458 & 0 & 0 & 0 & 1,618 & $\$ 48.13$ & 95 \\
\hline Virginia & 4.34 & $\$ 53.76$ & 2.727 & 0 & 0 & 0 & 489 & $\$ 35.58$ & 96 \\
\hline \multirow[t]{2}{*}{ West Virginia } & 4.21 & $\$ 54.31$ & 816 & 0 & 0 & 0 & 53 & $\$ 34.99$ & 55 \\
\hline & & $\$ 53.86$ & 17,886 & 0 & 0 & 0 & 3,776 & $\$ 45.48$ & 486 \\
\hline & & & & & & & & & \\
\hline
\end{tabular}

Figures 6 and 7 show facility location and delivered prices as predicted by ORIBAS. At 110,000 dry ton/yr facility demand, ORIBAS identified 52 sites whose marginal delivered switchgrass feedstock price was $\$ 29.23$ to $\$ 34.38 /$ dry ton. The sites roughly fell into three clusters. One cluster ran southwest to northeast parallel to the eastern Tennessee border between the Smoky Mountains and the Cumberland Plateau. The largest and lowest-cost cluster fell loosely around Nashville. A third cluster fell in the western quarter of the state avoiding the counties near Memphis. At a 700,000 dry ton/yr facility demand ORIBAS identified 8 sites whose marginal delivered switchgrass feedstock price ranged from $\$ 33.57$ to $\$ 37.44$. Four of the sites were located in the western eighth of the state. Three sites were loosely scattered across the central third of the state, and only one site was located in the eastern side of the state. The shift from an eastern to middle Tennessee focus for facilities with small feedstock demands to a middle 


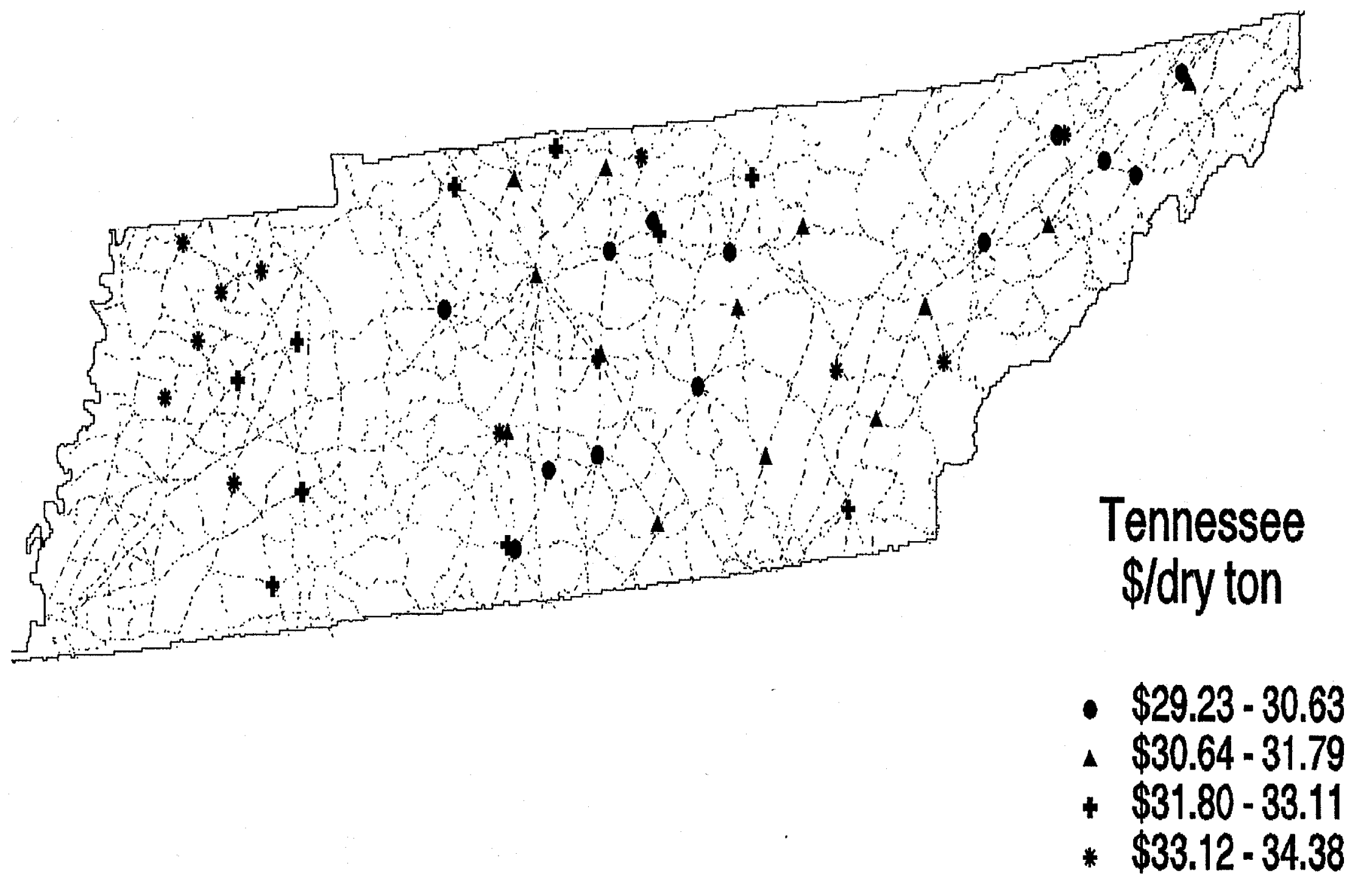

Fig. 6. Location and marginal delivered switchgrass price of lowest cost 110,000 ton/yr facility sites in Tennessee. 


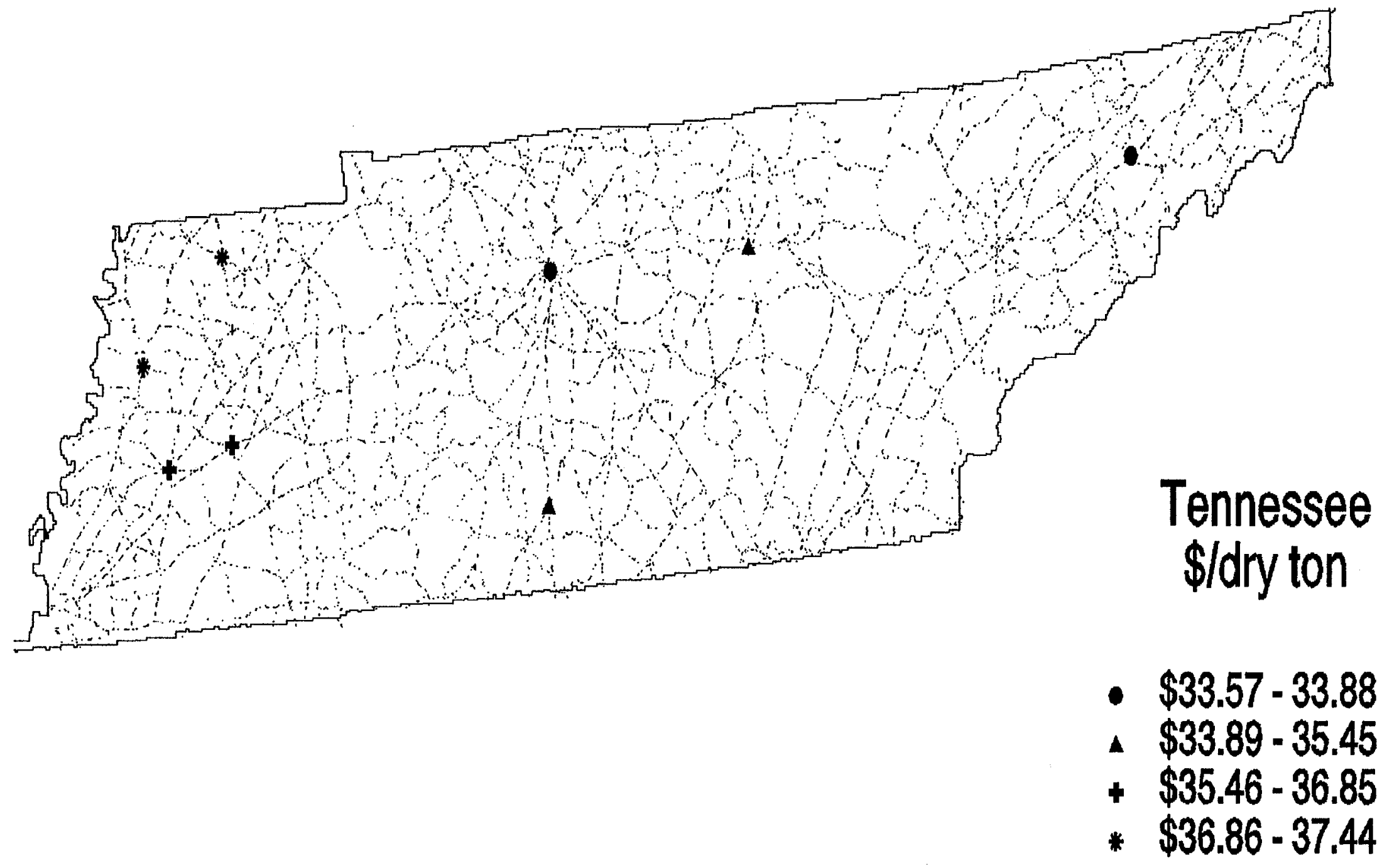

Fig. 7. Location and marginal delivered switchgrass price of lowest cost $\mathbf{7 0 0 , 0 0 0}$ ton/yr facility sites in Tennessee. 
to western focus for facilities with large feedstock demands is due to the land-use patterns across the state. While the farmgate prices of feedstocks were least costly in the East, there is so little cropland that the transport costs to amass 700,000 dry tons from approximately 110,000 acres made eastern Tennessee undesirable for large facilities solely dependent on switchgrass. This might be remedied if cropland currently used for pasture was considered in the land base for possible switchgrass production.

\section{CORNBELT REGION}

With a few exceptions, the cornbelt (Fig. 8) has high farmgate prices ( $>\$ 45 /$ dry ton) for both switchgrass and hybrid poplar (Tables 4 and 5). While expected yields are fairly high for both energy crops, the value of the land for growing conventional crops raises the overall production costs quite significantly. Energy crop farmgate prices are moderate in only three locations-along the border area of Iowa and Missouri, the southeast section of Ohio, and the south central portion of Missouri (switchgrass only). The latter two locations, however, have fairly low cropland density and could not support a large demand for energy crop biomass.

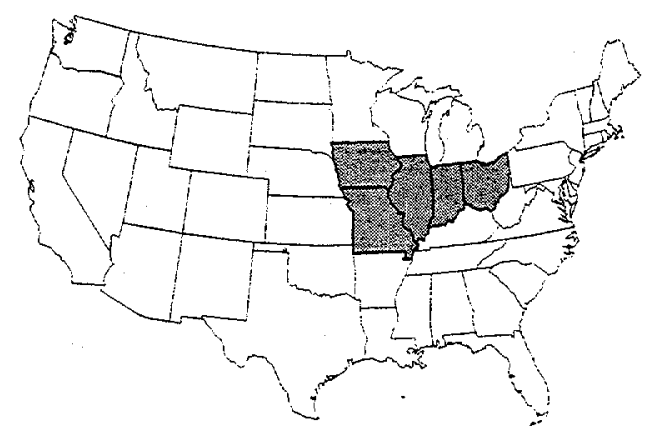

Fig. 8. Cornbelt Region

\section{ORIBAS Switchgrass Analysis - Missouri and Iowa}

The ORIBAS estimates of farmgate prices of Iowa and Missouri and their spatial pattern mirror the ORECCL estimates. The most promising area in Iowa is the south central area. While the overall farmgate prices for Missouri predicted by ORIBAS and ORECCL are comparable ( $\$ 35$ vs $\$ 39 /$ dry ton), the spatial patterns are somewhat different. ORIBAS analysis predicts the southwest corner of the state to have the greatest promise for producing low-cost switchgrass (under $\$ 30 /$ dry ton), while ORECCL suggests that the northern central section might also be a low-cost area.

At 110,000 dry ton/yr facility demand, ORIBAS identified 319 sites in Iowa whose marginal delivered switchgrass feedstock price was $\$ 42.54$ to $\$ 51.63 /$ dry ton with most of the sites strongly skewed towards the higher end of the price range (Fig. 9). The 
Table 4. Short-Rotation Woody Crops - Cornbelt Region

\begin{tabular}{|c|c|c|c|c|c|c|c|c|c|}
\hline SRWC & $\begin{array}{c}\text { Average } \\
\text { yield } \\
\text { (tonlacrefive? }\end{array}$ & $\begin{array}{c}\text { ORECCL } \\
\text { Average } \\
\text { farmgate } \\
\text { price } \\
\text { [ifton] } \\
\end{array}$ & $\begin{array}{l}\text { Acreage of } \\
\text { cropland } \\
\text { suitable for } \\
\text { SRWC } \\
(1000)\end{array}$ & $\begin{array}{c}\text { ORECCL } \\
\text { Acreage of } \\
\text { land with } \\
\text { farmgate } \\
\text { price }<\$ 35 \\
(000) \\
\end{array}$ & $\begin{array}{c}\text { ORECCL } \\
\text { Acreage of } \\
\text { land with } \\
\text { farmgate } \\
\text { orice }<\$ 40 \\
(000) \\
\end{array}$ & $\begin{array}{l}\text { ORECCL } \\
\text { Acreage of } \\
\text { land with } \\
\text { farmigate } \\
\text { price }<\$ 45 \\
\text { (C00) }\end{array}$ & $\begin{array}{c}\text { DRECCL } \\
\text { Acreage of } \\
\text { land with } \\
\text { farmogate } \\
\text { price }<\$ 50 \\
\{000\} \\
\end{array}$ & $\begin{array}{l}\text { ORECCLL } \\
\text { Average } \\
\text { cast rent } \\
\text { S/acre/yol }\end{array}$ & $\begin{array}{l}\text { Number } \\
\text { of } \\
\text { counties }\end{array}$ \\
\hline Itinois & 5.00 & $\$ 65.46$ & 23.154 & 0 & 0 & 0 & 13 & $\$ 105.25$ & 102 \\
\hline Jackena & 5.00 & $\$ 61.65$ & 12,623 & 0 & 0 & 0 & 0 & $\$ 89.60$ & 82 \\
\hline lowe & 4.99 & $\$ 67.13$ & 24,984 & 0 & 0 & 0 & 0 & $\$ 111.78$ & 99 \\
\hline Missouri & 4.78 & $\$ 58.56$ & 13,796 & 0 & 0 & 0 & 605 & $\$ 68.41$ & 114 \\
\hline Dhio & 4.87 & $\$ \$ 8.33$ & 10,569 & 0 & 0 & 77 & 77 & $\$ 71.33$ & 88 \\
\hline & & $\$ 63.38$ & 85,126 & 0 & 0 & $\eta$ & 695 & $\$ 94.67$ & 495 \\
\hline
\end{tabular}

Table 5. Switchgrass - Cornbelt Region

\begin{tabular}{|c|c|c|c|c|c|c|c|c|c|c|c|c|}
\hline SWG & $\begin{array}{l}\text { Average } \\
\text { yield } \\
\text { (toniacre/yr) }\end{array}$ & $\begin{array}{c}\text { ORECCL } \\
\text { Avarage } \\
\text { farmgate } \\
\text { price } \\
\text { (\$lton) }\end{array}$ & $\begin{array}{l}\text { Acreage of } \\
\text { cropland } \\
\text { suitable for } \\
\text { Swt (lDOO) }\end{array}$ & $\begin{array}{l}\text { ORECCL } \\
\text { Acreage of } \\
\text { land with } \\
\text { farmpate } \\
\text { price }<\$ 30 \\
\text { (COO) }\end{array}$ & $\begin{array}{l}\text { ORECCL } \\
\text { Acresge of } \\
\text { land with } \\
\text { farmgate } \\
\text { price }<\$ 35 \\
\text { (000) }\end{array}$ & $\begin{array}{c}\text { ORECCL } \\
\text { Atreage of } \\
\text { land with } \\
\text { tarmgate } \\
\text { price <\$40 } \\
(000)\end{array}$ & $\begin{array}{c}\text { ORECCL } \\
\text { Acreage of } \\
\text { land with } \\
\text { farmgate } \\
\text { price }<\$ 45 \\
(000)\end{array}$ & $\begin{array}{l}\text { ORECCL } \\
\text { Average } \\
\text { cash rent } \\
\text { S|acrelyri) }\end{array}$ & $\begin{array}{l}\text { Number } \\
\text { of } \\
\text { counties }\end{array}$ & $\begin{array}{l}\text { ORIBAS } \\
\text { Aversge land } \\
\text { rent } \\
\text { \$jacre/vil }\end{array}$ & $\begin{array}{c}\text { ORlBAS } \\
\text { Average } \\
\text { farngate } \\
\text { price } \\
\text { \$lton }\end{array}$ & $\begin{array}{l}\text { Formpgate } \\
\text { price } \\
\text { difference } \\
\text { ORIBAS. } \\
\text { ORECCL }\end{array}$ \\
\hline Illineis & 5.96 & $\$ 48.20$ & 23,154 & 0 & 13 & 2,813 & 7,683 & $\$ 105.26$ & $10 t$ & & & \\
\hline Indiana & 5.91 & $\$ 45.11$ & 12,623 & 0 & 0 & 1,484 & 8,982 & $\$ 89.60$ & 92 & & & \\
\hline lowa & 6.00 & $\$ 49.27$ & 24,984 & 0 & 113 & 1,609 & 6,329 & $\$ 111.78$ & 99 & $\$ 106.83$ & $\$ 48.43$ & $\{\$ 2.84\}$ \\
\hline Misseuri & 6.09 & $\$ 39.72$ & 13,796 & 0 & 1.705 & 9,049 & 31,742 & $\$ 68.41$ & 114 & $\$ 58.50$ & $\$ 35.93$ & $(\$ 3.79)$ \\
\hline \multirow[t]{2}{*}{ Ohio } & 5.77 & $\$ 41.83$ & 10,569 & 0 & $7: 9$ & 4,124 & 8,140 & $\$ 71.33$ & 88 & & & \\
\hline & & $\$ 46.89$ & 85.128 & 0 & 2,650 & 19,079 & 40,876 & $\$ 94.67$ & 495 & & & \\
\hline
\end{tabular}

sites were evenly distributed across the state. While lowest cost sites could be found virtually anywhere across the state, the central south section of the state was the best location. At a 700,000 dry ton/yr facility demand, ORIBAS identified 50 sites whose marginal delivered switchgrass feedstock price ranged from $\$ 46.66$ to $\$ 53.82$ (Fig. 10). The spatial pattern of site locations and price was the same as for the smaller facilities.

At $110,000 \mathrm{dry}$ ton/yr facility demand, ORIBAS identified 135 sites in Missouri whose marginal delivered switchgrass feedstock price was $\$ 29.95$ to $\$ 42.77 /$ dry ton with the sites generally skewed towards the higher end of the price range (Fig. 11). The heavily forested southeast section of the state was devoid of sites except for the southeast boot-heel of the state on the Mississippi River. The northwest corner of the state was also devoid of sites, because of the high farmgate prices associated with that region. The lowest cost sites were generally found in the southwest quarter of the state. At a 700,000 dry ton/yr facility demand ORIBAS identified 50 sites whose marginal delivered switchgrass feedstock price ranged from $\$ 35.57$ to $\$ 46.24$ (Fig.12). As in Iowa, the spatial pattern of site locations and price was the same for the smaller and the larger facilities. 


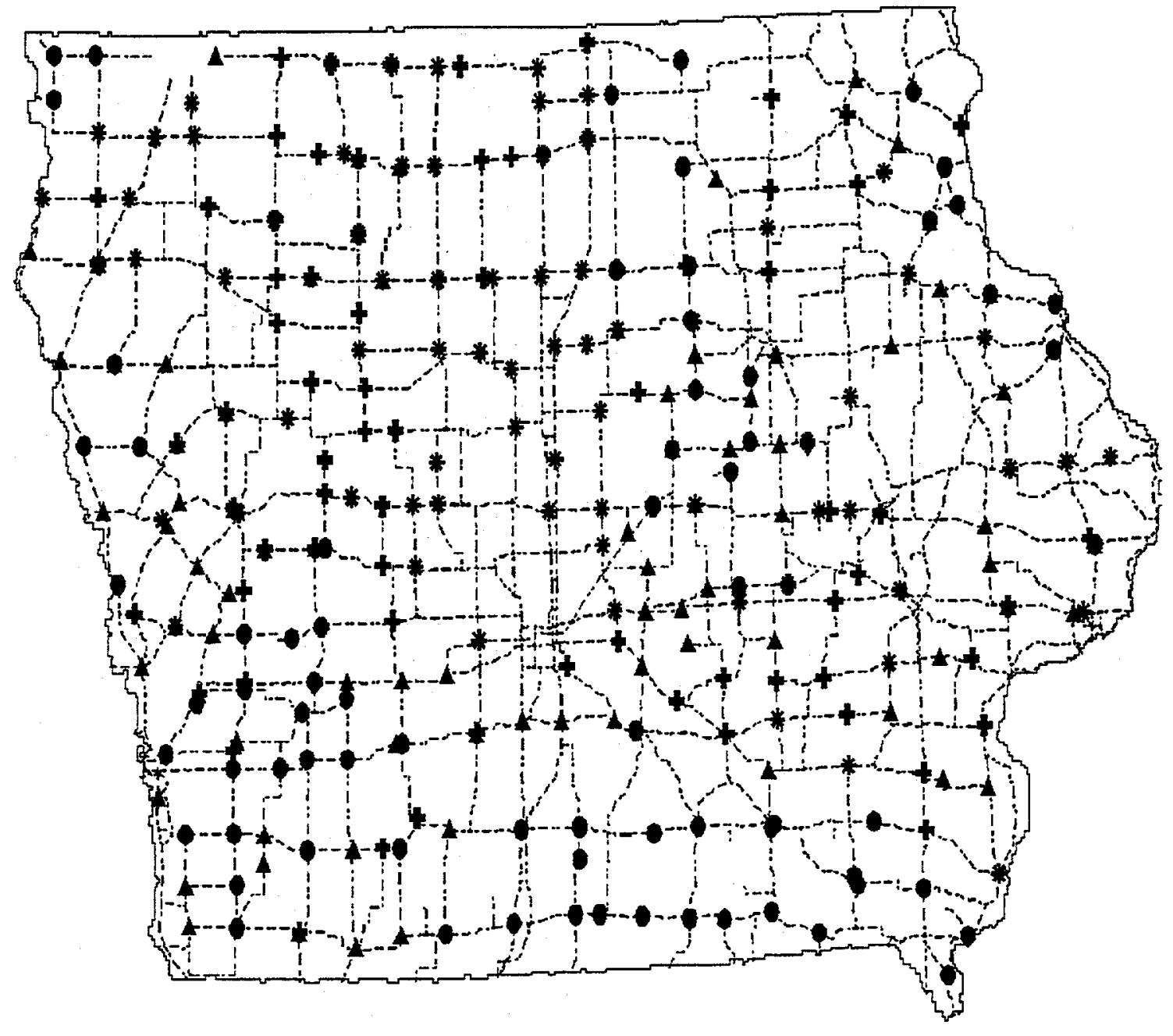

lowa
$\$ / d r y$ ton

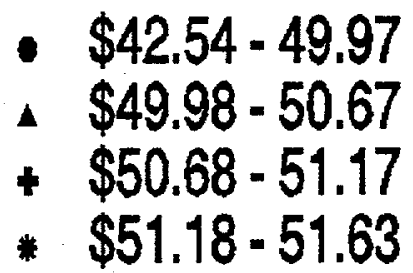

Fig. 9. Location and marginal delivered switchgrass price of lowest cost 110,000 ton/yr facility sites in Iowa. 

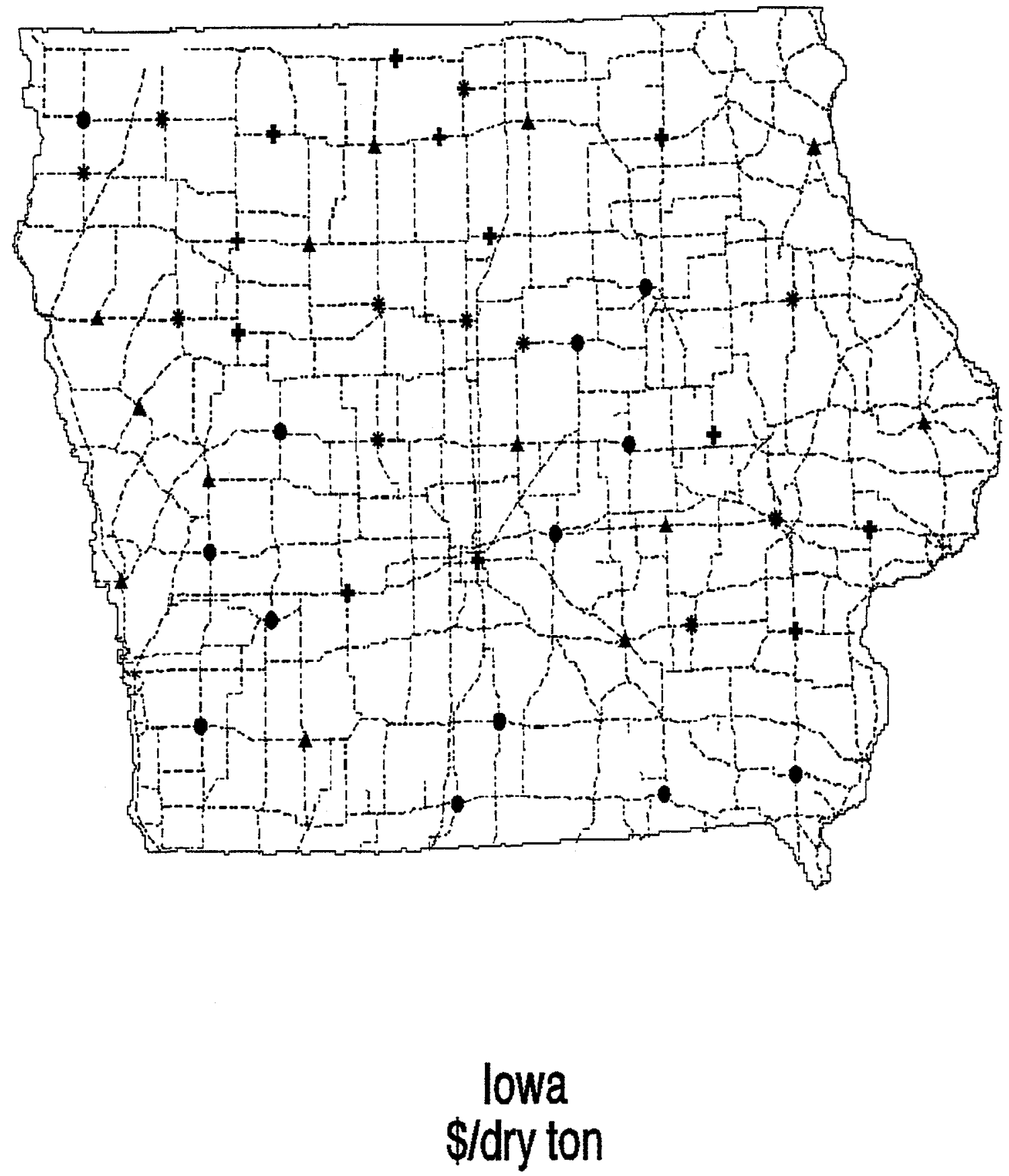

- $\$ 46.66 \cdot 52.51$

- $\$ 52.52-52.91$

$+\$ 52.92-53.22$

* $\$ 53.23-53.82$

Fig. 10. Location and marginal delivered switchgrass price of lowest cost 700,000 ton/yr facility sites in Iowa. 


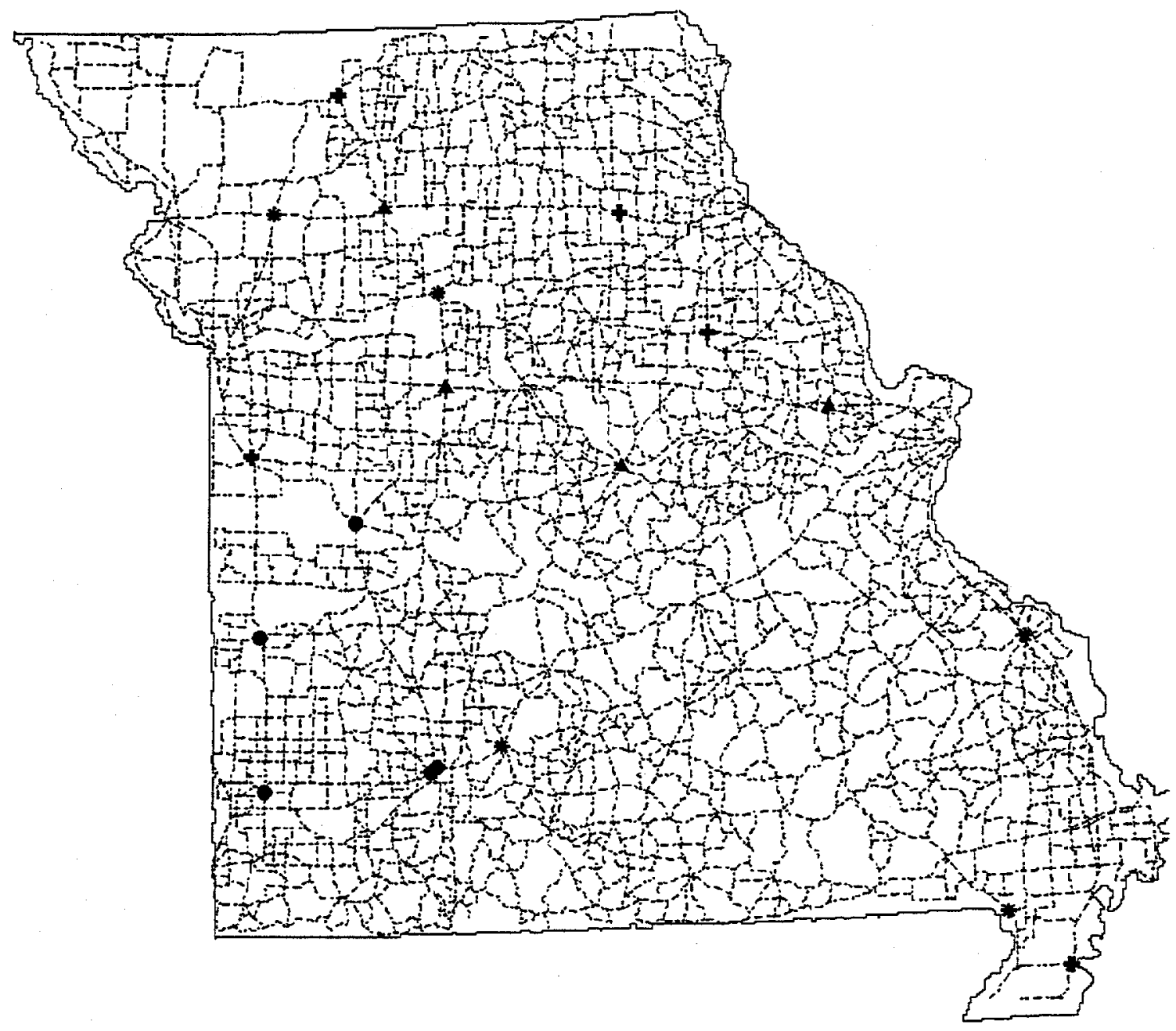

Missouri
$\$ /$ dry ton

- $\$ 35.57-41.23$

- $\$ 41.24-43.83$

$+\$ 43.84-44.88$

$* \$ 44.89-46.24$

Fig. 11. Location and marginal delivered switchgrass price of lowest cost 110,000 ton/yr facility sites in Missouri. 


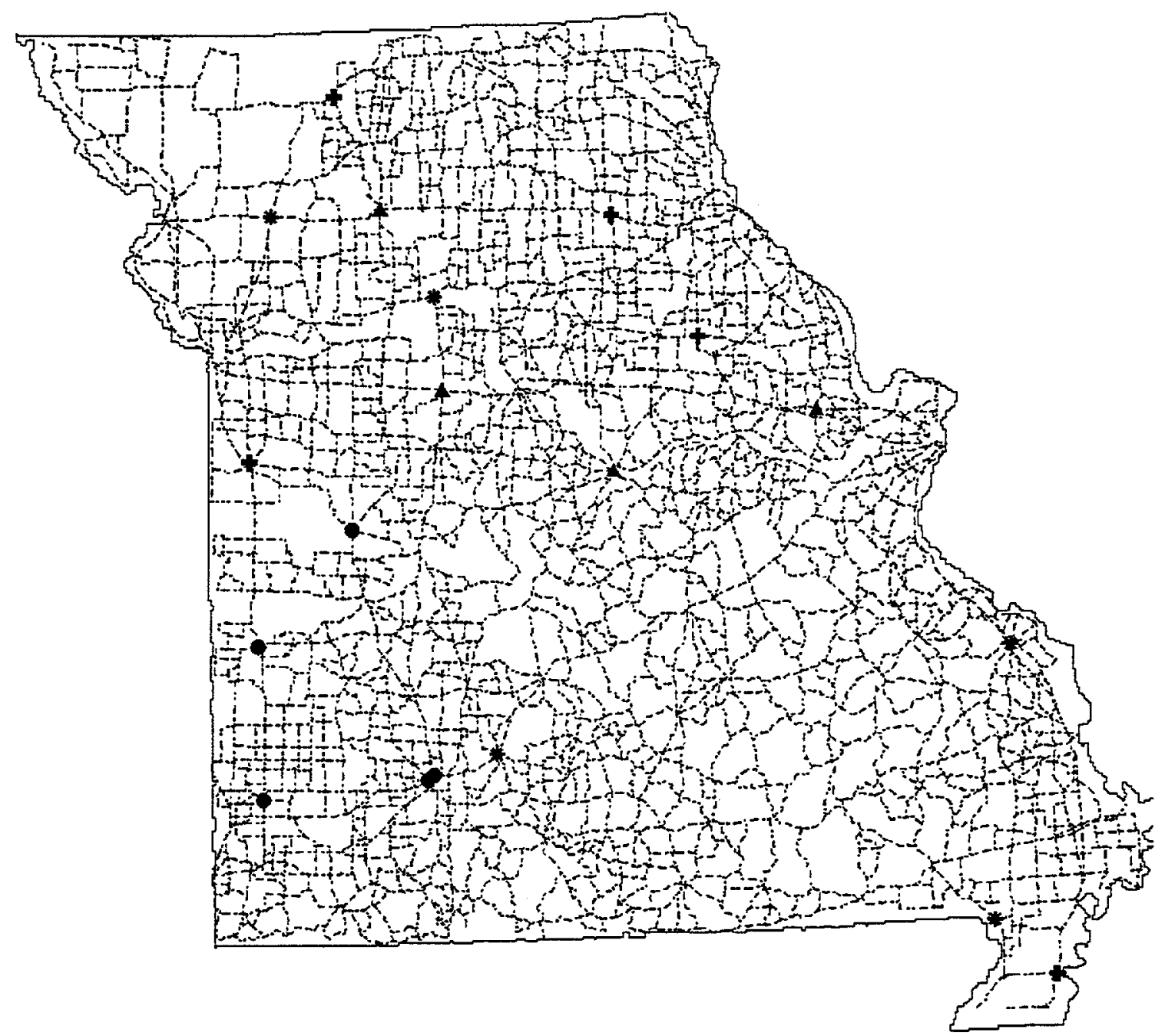

\section{Missouri $\$ /$ dry ton}

- $\$ 35.57-41.23$

- $\$ 41.24-43.83$

+ $\$ 43.84-44.88$

$* \$ 44.89-46.24$

Fig. 12. Location and marginal delivered switchgrass price of lowest cost 700,000 ton/yr facility sites in Missouri. 


\section{DELTA REGION}

Overall, the Delta states (Fig. 13) would appear to be a promising region for switchgrass production. Hybrid poplar farmgate prices are also comparatively low ( $\leq \$ 50 /$ dry ton) in much of Mississippi and along the eastern border of Arkansas and Louisiana due to high expected yields in the Mississippi River floodplain (Table 6). Farmgate prices for switchgrass are projected to be under $\$ 35 /$ dry ton throughout the region except for the southern half of Louisiana (Table 7). The wet soils in southern Louisiana are likely to depress switchgrass yields and thus raise prices.

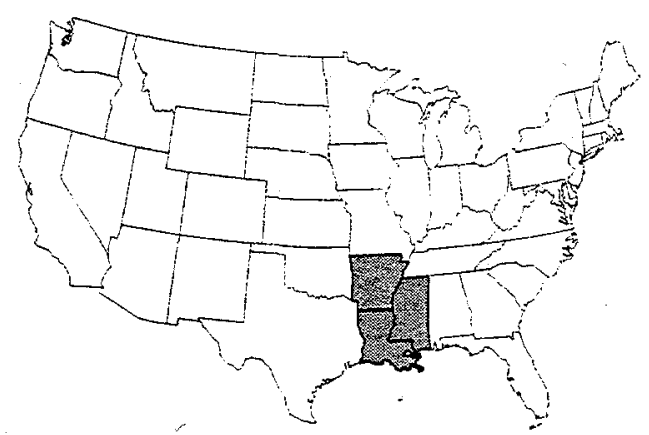

Fig. 13. Delta Region.

Table 6. Short Rotation Woody Crops - Delta

\begin{tabular}{|c|c|c|c|c|c|c|c|c|c|}
\hline SAWC & $\begin{array}{l}\text { Average } \\
\text { yreed } \\
\text { (10alacre/yn) }\end{array}$ & $\begin{array}{l}\text { ORECCL } \\
\text { Average } \\
\text { farmgate } \\
\text { price } \\
\text { (\$thon) }\end{array}$ & $\begin{array}{l}\text { Acreage of } \\
\text { cropland } \\
\text { suitable for } \\
\text { SRWC } \\
\text { [OCO) }\end{array}$ & $\begin{array}{l}\text { ORECCL } \\
\text { Acreage of } \\
\text { land with } \\
\text { farmgate } \\
\text { grice }<\$ 35 \\
(000)\end{array}$ & $\begin{array}{c}\text { ORECCL } \\
\text { Acreage of } \\
\text { land with } \\
\text { farmgate } \\
\text { price }<\$ 40 \\
\text { (000) }\end{array}$ & $\begin{array}{c}\text { ORECCL } \\
\text { Acreage of } \\
\text { land with } \\
\text { farmgate } \\
\text { price <\$45 } \\
(000)\end{array}$ & $\begin{array}{c}\text { OAECCL } \\
\text { Acreage of } \\
\text { land with } \\
\text { farngate } \\
\text { price }<\$ 50 \\
(000)\end{array}$ & $\begin{array}{l}\text { ORECCL } \\
\text { Average } \\
\text { cash rent } \\
\text { Slacre/fr] }\end{array}$ & $\begin{array}{l}\text { Number } \\
\text { of } \\
\text { counties }\end{array}$ \\
\hline Arkansas & 4.79 & $\$ 53.19$ & 7,973 & 0 & 0 & 0 & 1.844 & $\$ 49.29$ & 75 \\
\hline Louisiana & 4.81 & $\$ 52.17$ & 4,856 & 0 & 0 & 0 & 1.766 & $\$ 45.36$ & 64 \\
\hline \multirow[t]{2}{*}{ Mississippi } & 4.86 & $\$ 50.35$ & 5.163 & 0 & 0 & 0 & 2,658 & $\$ 39.94$ & $B 2$ \\
\hline & & $\$ 52.10$ & 13,792 & 0 & 0 & 0 & 6,268 & $\$ 45.55$ & 221 \\
\hline
\end{tabular}

Table 7. Switchgrass - Delta Region

\begin{tabular}{|c|c|c|c|c|c|c|c|c|c|}
\hline SWG & $\begin{array}{l}\text { Average } \\
\text { yiedd } \\
\text { (ton/acre/yr) }\end{array}$ & $\begin{array}{l}\text { ORECCL } \\
\text { Average } \\
\text { farmigate } \\
\text { price } \\
\text { | \$\$ton) }\end{array}$ & $\begin{array}{l}\text { Acreage of } \\
\text { cropland } \\
\text { suitable for } \\
\text { SWG ((000) }\end{array}$ & $\begin{array}{l}\text { ORECCLL } \\
\text { Acreage of } \\
\text { land with } \\
\text { tarmgate } \\
\text { price }<\$ 30 \\
\text { (ODD) }\end{array}$ & $\begin{array}{l}\text { ORECCLL } \\
\text { Acreage of } \\
\text { land with } \\
\text { farmgate } \\
\text { price }<\$ 35 \\
\text { [000] }\end{array}$ & $\begin{array}{l}\text { ORECCL } \\
\text { Acresge of } \\
\text { land with } \\
\text { larmgate } \\
\text { price }<\$ 40 \\
(000)\end{array}$ & $\begin{array}{l}\text { ORECCL } \\
\text { Acreage of } \\
\text { iand with } \\
\text { farmgate } \\
\text { price <\$45 } \\
\text { (080) }\end{array}$ & $\begin{array}{l}\text { ORECCL } \\
\text { Average } \\
\text { cash rent } \\
\text { \$lacrelyit }\end{array}$ & $\begin{array}{l}\text { Number } \\
\text { of } \\
\text { costios }\end{array}$ \\
\hline Arkansas & 6.09 & $\$ 35.24$ & 7,973 & 34 & 4,181 & 2.805 & 7,967 & $\$ 49.29$ & 75 \\
\hline Louisiana & 5.37 & $\$ 37.85$ & 4,656 & 0 & 2.127 & 3.177 & 3.525 & $\$ 45.36$ & 64 \\
\hline \multirow[t]{2}{*}{ Mississippi } & 5.99 & $\$ 33.56$ & 5,163 & 0 & 4,402 & 5,147 & 5.147 & $\$ 39.94$ & 82 \\
\hline & & $\$ 35.46$ & 17,792 & 34 & 10,710 & 18.129 & 16,639 & $\$ 45.55$ & 221 \\
\hline
\end{tabular}




\section{LAKE STATES REGION}

Low cost willow production in the northern counties of the Lake States Region (Fig. 14) dominate the short rotation woody crop farmgate prices (Table 8). These should be viewed with considerable caution as willow yield trials have only just been initiated in the region thus the yields assumed in ORECCL are purely educated conjecture.

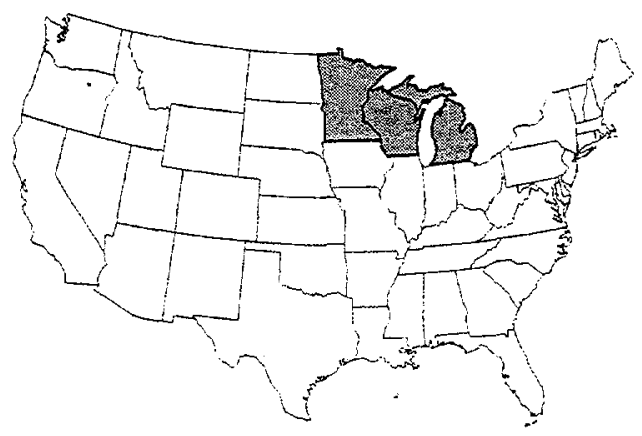

Fig. 14. Lake States Region.

Switchgrass prices were uniformly in the range of $\$ 35$ to $\$ 40$ (Table 9). Prices were higher near the Red River Valley in Minnesota and adjacent to the cornbelt (the southern portions of the states). Not surprisingly, urban centers (Minneapolis, Milwaukee, Detroit) affected the pattern predicted by ORECCL. The switchgrass yields for this region are largely based on educated conjecture and should, therefore, be viewed with some caution.

\section{ORIBAS Analysis - Minnesota}

The gross pattern reflected by ORECCL was mirrored by the ORIBAS analysis. Lands along the prairie/forest boundary were generally promising. The ORIBAS analysis predicted that an area around Swift County in the western portion of the state just north of the Minnesota River might be the best area with substantial acreages with prices around \$30/dry ton. South of this region, the land is too valuable for corn and soybean production. The ORECCL database also picked up this region as especially promising. Minnesota displayed the greatest variation in delivered feedstock costs of the elevens state analyzed with ORIBAS.

At 110,000 dry ton/yr facility demand, ORIBAS identified 188 sites whose marginal delivered switchgrass feedstock price was $\$ 30.56$ to $\$ 45.74 /$ dry ton with the sites strongly skewed towards the higher end of the price range (Fig. 15). Low-cost sites were along the western boundary of the state and along the prairie/forest border which runs diagonally across the state from Minneapolis at the southeast to near Fargo, North Dakota, at the northwest. At a 700,000 dry ton/yr facility demand ORIBAS identified 28 sites whose marginal delivered switchgrass feedstock price ranged from $\$ 34.86$ to $\$ 48.36$ (Fig. 16). 
Table 8. Short Rotation Woody Crops - Lake States Region

\begin{tabular}{|c|c|c|c|c|c|c|c|c|c|}
\hline SRWC & $\begin{array}{l}\text { Average } \\
\text { yield } \\
\text { (ton/acrefyrt) }\end{array}$ & $\begin{array}{l}\text { ORECCL } \\
\text { Average } \\
\text { farmgate } \\
\text { price } \\
\text { (sttent }\end{array}$ & $\begin{array}{l}\text { Acreage of } \\
\text { cropland } \\
\text { suitable for } \\
\text { SRWC } \\
(1000)\end{array}$ & $\begin{array}{l}\text { ORECCI } \\
\text { Acreage of } \\
\text { land with } \\
\text { farmote } \\
\text { price }<\$ 35 \\
1000 \text { \% }\end{array}$ & $\begin{array}{c}\text { ORECCL } \\
\text { Acreage of } \\
\text { land with } \\
\text { farmgate } \\
\text { price }<\$ 40 \\
\text { (000) }\end{array}$ & $\begin{array}{c}\text { ORECCL } \\
\text { Acreape of } \\
\text { bnd with } \\
\text { farmgate } \\
\text { price }<\$ 45 \\
{[000]}\end{array}$ & $\begin{array}{c}\text { OAECCCL } \\
\text { Acreage of } \\
\text { land with } \\
\text { famgate } \\
\text { price }<\$ 50 \\
(000)\end{array}$ & $\begin{array}{l}\text { ORECCL } \\
\text { Average } \\
\text { cash reat } \\
\text { s/acre/vit }\end{array}$ & $\begin{array}{l}\text { Munber } \\
\text { of } \\
\text { cosmties }\end{array}$ \\
\hline Michigan & 5.03 & $\$ 49,80$ & 7,339 & 71 & 796 & 926 & 3,589 & $\$ 46.39$ & 81 \\
\hline Minnesota & 4.74 & $\$ 58.01$ & 20.115 & 0 & 684 & 747 & 908 & $\$ 66.22$ & 87 \\
\hline Wisconsin & 4.96 & $\$ 52.54$ & 9,509 & 0 & 666 & 1,348 & 2.053 & $\$ 54.92$ & 71 \\
\hline & & $\$ 54.97$ & 36,983 & 71 & 2,146 & 3,021 & 6,550 & $\$ 59.38$ & 239 \\
\hline
\end{tabular}

Table 9. Switchgrass - Lake States Region

\begin{tabular}{|c|c|c|c|c|c|c|c|c|c|}
\hline SWG & $\begin{array}{l}\text { Averaga } \\
\text { vield } \\
\text { (tonlacrelyr) }\end{array}$ & $\begin{array}{l}\text { ORECCL } \\
\text { Averzge } \\
\text { farmagte } \\
\text { price } \\
\text { (\$thon) }\end{array}$ & $\begin{array}{l}\text { Acrease of } \\
\text { cropland } \\
\text { suitasls for } \\
\text { SwG (tDOO) }\end{array}$ & $\begin{array}{l}\text { ORECLL } \\
\text { Acreage of } \\
\text { land with } \\
\text { farmgate } \\
\text { price }<\$ 30 \\
(000)\end{array}$ & $\begin{array}{c}\text { ORECCL } \\
\text { Acreage of } \\
\text { land with } \\
\text { farmgate } \\
\text { price }<\$ 35 \\
(000)\end{array}$ & $\begin{array}{l}\text { ORECCL } \\
\text { Acreage of } \\
\text { tand with } \\
\text { farrmgate } \\
\text { price }<\$ 40 \\
\text { (C00) }\end{array}$ & $\begin{array}{c}\text { ORECCL } \\
\text { Acreags of } \\
\text { land with } \\
\text { larmgate } \\
\text { price < } \$ 45 \\
(000)\end{array}$ & $\begin{array}{l}\text { ORECCLL } \\
\text { Avesapge } \\
\text { cash rent } \\
\text { Slacre/yt) }\end{array}$ & $\begin{array}{l}\text { Humber } \\
\text { of } \\
\text { counties }\end{array}$ \\
\hline Michigan & 5.04 & $\$ 39.18$ & 7,339 & 0 & 371 & 5,120 & 6,937 & $\$ 46.39$ & 81 \\
\hline Minnesata & 5.41 & $\$ 42.41$ & 20,115 & 0 & 67 & 7.230 & 15,770 & $\$ 66.22$ & 87 \\
\hline \multirow[t]{2}{*}{ Wisconsin } & 5.11 & $\$ 41.26$ & 9.509 & 0 & 631 & 3,969 & 8,091 & $\$ 54.92$ & 7 \\
\hline & & $\$ 41.47$ & 36,963 & 0 & 1,069 & 16,319 & 30,798 & $\$ 59.38$ & 239 \\
\hline
\end{tabular}




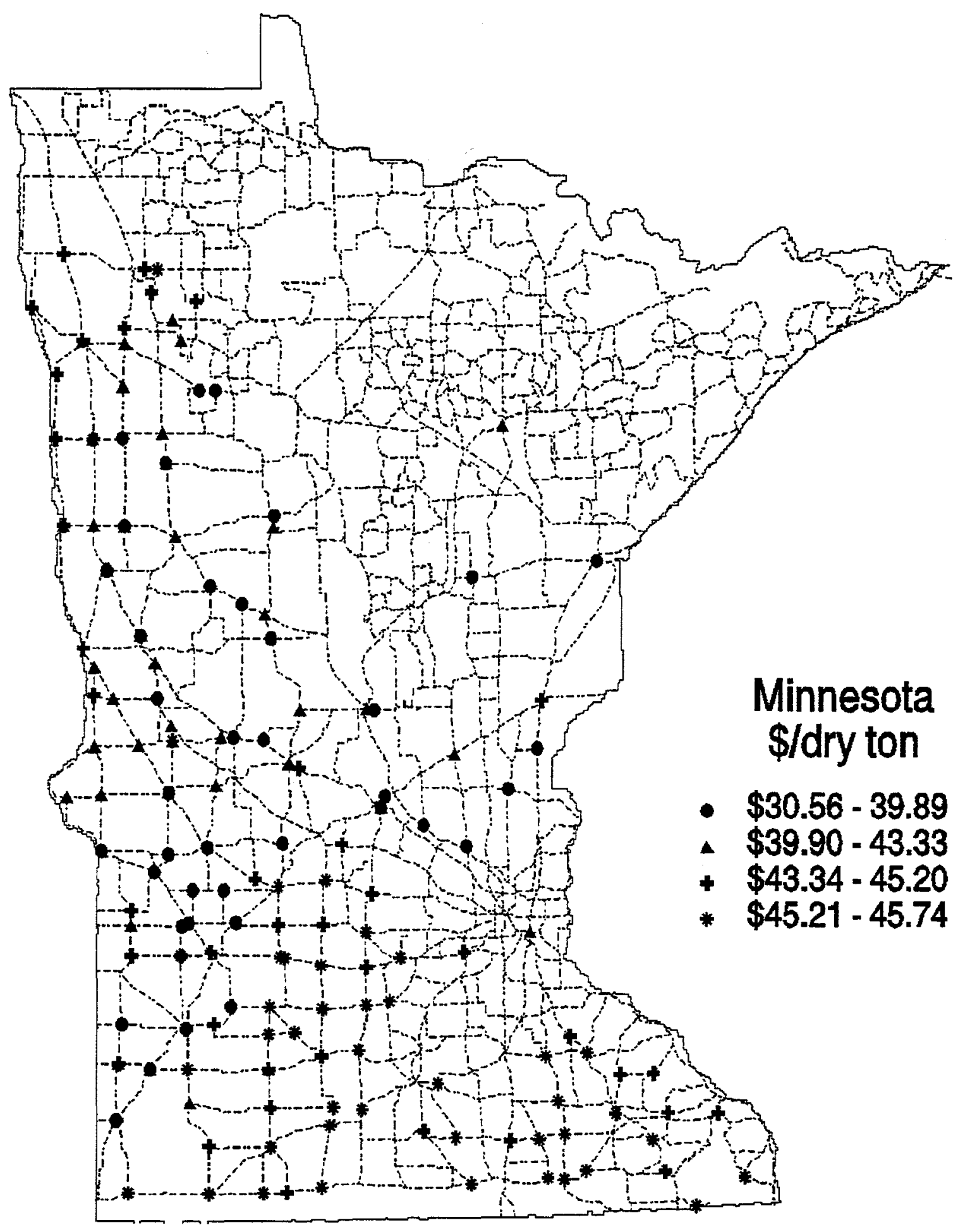

Fig. 15. Location and marginal delivered switchgrass price of lowest cost 110,000 ton/yr facility sites in Minnesota. 


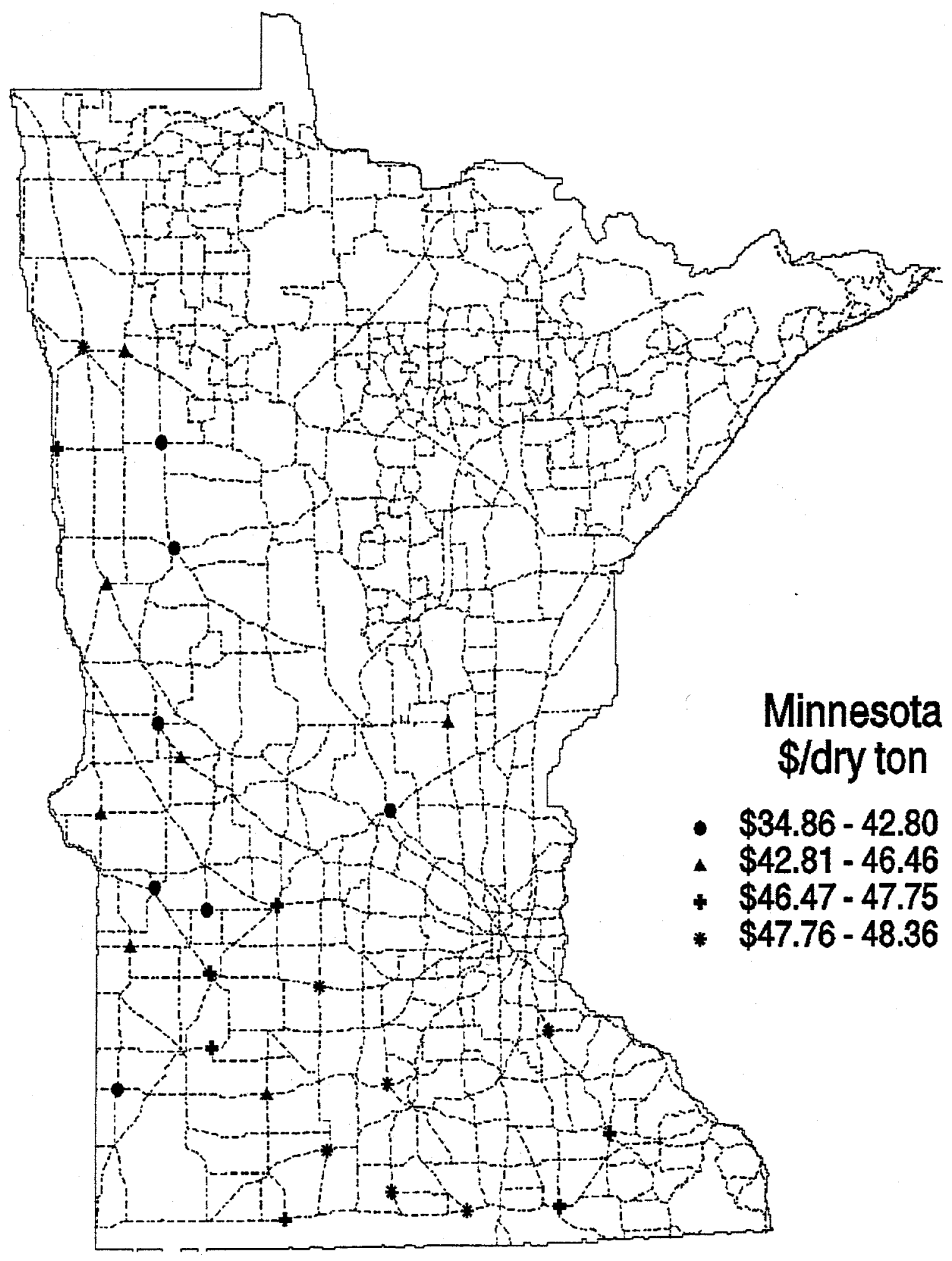

Fig. 16. Location and marginal delivered switchgrass price of lowest cost 700,000 ton/yr facility sites in Minnesota. 


\section{NORTHEAST REGION}

This region (Fig. 17) has some of the lowest short rotation woody crop farmgate prices due to low cost willow production ${ }^{6}$ and low cash rents. The willow yields (6-to 6.5 tons/yr) are based on work in central New York and may be optimistic for other areas (Table 10). Willow yields in southern Quebec and Ontario were 3 to 5 tons/acre (Samson et al. 1997). Nonetheless, New York would appear promising for either herbaceous or woody crops. The state has significant cropland acreage at low cash rents. The western portion of Pennsylvania and central Massachusetts might also be good sites for small bioenergy facilities.

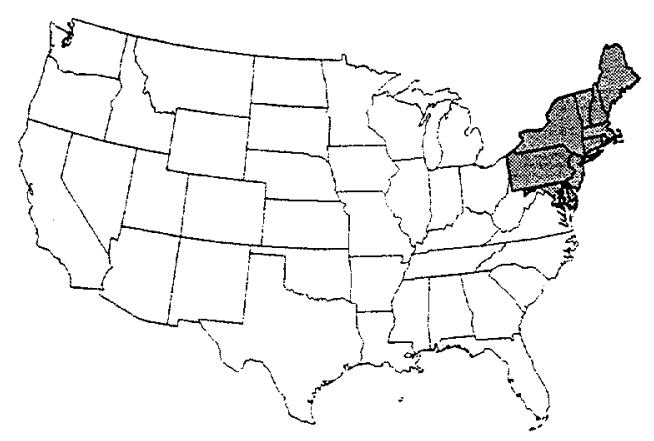

Fig. 17. Northeast Region.

Any conclusions with regards to promising locations for switchgrass crops in the Northeast must be viewed with great caution. The yield assumptions for switchgrass are based on observed hay yields and educated conjecture (Table 11). No switchgrass yield data are available for this region. Some switchgrass yield data from southern Quebec and from Ontario, Canada, do, however, support these values of 4 to 5 tons/acre/yr (Samson et al. 1997). Samson also estimated a farmgate price of $\sim 35$ to $\$ 46$ dry ton for southern Ontario. Switchgrass yields trials are being initiated in the northeast region, so more solid information will soon be available.

\footnotetext{
${ }^{6}$ These prices will probably increase significantly in future assessments as revised willow production costs are now estimated to be considerably higher than those used in version 1 of BIOCOST.
} 
Table 10. Short Rotation Woody Crops - Northeast Region

\begin{tabular}{|c|c|c|c|c|c|c|c|c|c|}
\hline SRWC & $\begin{array}{c}\text { Average } \\
\text { vield } \\
\text { (tondacrefyz) }\end{array}$ & $\begin{array}{c}\text { ORECCL } \\
\text { Average } \\
\text { farmgata } \\
\text { price } \\
\text { (\$shon) } \\
\end{array}$ & $\begin{array}{l}\text { Acreage of } \\
\text { cropland } \\
\text { suitable for } \\
\text { SRHC } \\
(1000)\end{array}$ & $\begin{array}{c}\text { ORECCL } \\
\text { Acreage of } \\
\text { land with } \\
\text { farmgate } \\
\text { price }<\$ 35 \\
\text { (000) } \\
\end{array}$ & $\begin{array}{c}\text { ORECCL } \\
\text { Acreage of } \\
\text { tand with } \\
\text { farmgate } \\
\text { price }<\$ 40 \\
\{000 \mid \\
\end{array}$ & $\begin{array}{c}\text { ORECCL } \\
\text { Acreage of } \\
\text { land with } \\
\text { farmgate } \\
\text { price }<\$ 45 \\
\text { (000) } \\
\end{array}$ & $\begin{array}{c}\text { ORECCL } \\
\text { Acreage of } \\
\text { land with } \\
\text { farmgate } \\
\text { price }<\$ 50 \\
\text { [000) } \\
\end{array}$ & $\begin{array}{l}\text { ORECCL } \\
\text { Average } \\
\text { cash rent } \\
\text { s/acrejyy } \\
\end{array}$ & $\begin{array}{c}\text { Number } \\
\text { of } \\
\text { counties }\end{array}$ \\
\hline Connecticut & 6.09 & $\$ 36.77$ & 146 & 24 & 130 & 141 & 141 & $\$ 50.30$ & 8 \\
\hline Delaware & 4.50 & $\$ 58.81$ & 446 & 0 & 0 & 0 & 0 & $\$ 58.06$ & 3 \\
\hline Maine & 4.13 & $\$ 49.69$ & 468 & 0 & 66 & 123 & 148 & $\$ 40.48$ & 16 \\
\hline Maryland & 4.49 & $\$ 58.11$ & 1,453 & 0 & 0 & 0 & 9 & $\$ 55.22$ & 23 \\
\hline Massachusetts & 5.43 & $\$ 39.29$ & 164 & 65 & 107 & 110 & 142 & $\$ 36.75$ & 11 \\
\hline New Hampshire & 5.37 & $\$ 39.51$ & 101 & 0 & 73 & 88 & 101 & $\$ 41.57$ & 10 \\
\hline New Jersey & 4.76 & $\$ 53.84$ & 477 & 31 & 83 & 83 & 146 & $\$ 51.81$ & 20 \\
\hline New York & 6.03 & $\$ 34.81$ & 3,916 & 3,160 & 3,404 & 3.531 & 3,577 & $\$ 34.77$ & 56 \\
\hline Pennsylvania & 4.73 & $\$ 52.73$ & 4,180 & 879 & 941 & 941 & 1,018 & $\$ 47.95$ & 65 \\
\hline Rhode Island & 6.00 & $\$ 37.91$ & 18 & 0 & 12 & 17 & 18 & $\$ 54.19$ & 5 \\
\hline \multirow[t]{2}{*}{ Vermont } & 5.05 & $\$ 42.23$ & 493 & 115 & 310 & 335 & 335 & $\$ 37.76$ & 14 \\
\hline & & $\$ 46.67$ & 11,862 & 4,274 & 5,126 & 5,369 & 5,633 & $\$ 44.13$ & 231 \\
\hline
\end{tabular}

Table 11. Switchgrass - Northeast Region

\begin{tabular}{|c|c|c|c|c|c|c|c|c|c|}
\hline SWG & $\begin{array}{c}\text { Average } \\
\text { yield } \\
\text { (tonjacre/ys| }\end{array}$ & $\begin{array}{c}\text { ORECCLL } \\
\text { Average } \\
\text { farmigate } \\
\text { price } \\
\text { (\$lton) } \\
\end{array}$ & $\begin{array}{c}\text { Acreage of } \\
\text { cropland } \\
\text { suitabte for } \\
\text { SWG }(1000)\end{array}$ & $\begin{array}{c}\text { ORECCLt } \\
\text { Acraege of } \\
\text { land with } \\
\text { tarngare } \\
\text { price }<\$ 30 \\
(000) \\
\end{array}$ & $\begin{array}{c}\text { ORECCL } \\
\text { Acreage of } \\
\text { land with } \\
\text { fammate } \\
\text { price }<\$ 35 \\
\text { (000) }\end{array}$ & $\begin{array}{l}\text { ORECCLL } \\
\text { Acreage of } \\
\text { land with } \\
\text { farmgate } \\
\text { price }<\$ 40 \\
(000)\end{array}$ & $\begin{array}{c}\text { ORECCL } \\
\text { Acreage of } \\
\text { land with } \\
\text { famngate } \\
\text { price }<\$ 45 \\
(000)\end{array}$ & $\begin{array}{l}\text { ORECCL } \\
\text { Average } \\
\text { cash rant } \\
\text { \$lacrefyr) } \\
\end{array}$ & $\begin{array}{c}\text { Number } \\
\text { of } \\
\text { counties }\end{array}$ \\
\hline Connecticut & 5.00 & $\$ 40.30$ & 145 & 0 & 0 & 105 & 130 & $\$ 50.30$ & $B$ \\
\hline Delaware & 3.39 & $\$ 55.54$ & 446 & 0 & 0 & 0 & 0 & $\$ 59.06$ & 3 \\
\hline Maine & - & - & - & - & - & - & - & - & 0 \\
\hline Maryiand & 4.30 & $\$ 47.37$ & 1,453 & 0 & 50 & 193 & 595 & $\$ 55.22$ & 23 \\
\hline Massechusetts & 5.00 & $\$ 38.18$ & 120 & 0 & 65 & 93 & 107 & $\$ 42.11$ & 9 \\
\hline New Hiampshire & 5.00 & $\$ 44.41$ & 27 & 0 & 0 & 6 & 16 & $\$ 66.30$ & 3 \\
\hline New Jersey & 5.41 & $\$ 38.93$ & 477 & 0 & 119 & 295 & 404 & $\$ 5 t .81$ & 20 \\
\hline New York & 5.00 & $\$ 36.48$ & 3,646 & 0 & 2,095 & 3,258 & 3,404 & $\$ 35.59$ & 50 \\
\hline Pennsylvania & 5.60 & $\$ 37.58$ & 4,180 & 325 & 1,803 & 2.878 & 3,680 & $\$ 47.95$ & 65 \\
\hline Rhode Island & 5.00 & $\$ 41.30$ & 18 & 0 & 0 & 10 & 17 & $\$ 54.19$ & 5 \\
\hline Vermont & 5.00 & $\$ 37.25$ & 191 & 0 & 0 & 157 & 191 & $\$ 38.39$ & 3 \\
\hline & & $\$ 39,40$ & 10.703 & 325 & 4,132 & 6.995 & 8.544 & $\$ 45.17$ & 109 \\
\hline
\end{tabular}




\section{NORTHERN PLAINS REGION}

If switchgrass yields of 4.0 dry tons or better can be achieved in this region (Fig. 18), it would be a very promising region for energy crops (Tables 12 and 13). Estimated profitability of conventional crops is low as are observed cropland cash rents. Furthermore, cropland density is high. The only unpromising areas are the Red River Valley and counties adjacent the Platte River in Nebraska.

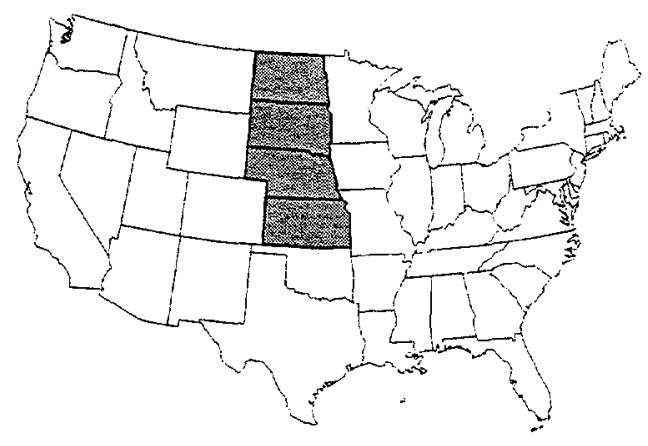

Fig. 18. Northern Plains Region

The low rainfall in this region inhibits the yields of woody crops and raises farmgate prices. However, pockets of land, especially in Kansas, might be suitable.

\section{ORIBAS Analysis- Nebraska, North Dakota and South Dakota}

The ORIBAS analysis shows significantly lower costs for switchgrass production in North Dakota and South Dakota than does ORECCL and somewhat higher costs than ORECCL for switchgrass in the northeast corner of Nebraska. These differences are entirely due to production cost differences generated by the two approaches to estimating the returns to land and management. The correct answer for North Dakota and South Dakota is probably closer to the ORIBAS estimate for all lands except those in the Red River Valley where sugar beets would influence the true value. Sugar beet profitability was not modeled in the ORIBAS analyses but would have been captured in the farmland value ratio for the counties.

The ORIBAS prediction of higher prices for energy crops in Nebraska as compared to North Dakota or South Dakota is because ORIBAS predicted a much higher per acre profit associated with conventional crop production in Nebraska and thus higher farmgate prices for switchgrass. While ORIBAS assumes unirrigated production costs, the databases used in the ORIBAS algorithms do not differentiate irrigated yields and land from unirrigated yields and land. In the case of eastern Nebraska, where a considerable portion of the conventional cropland acreage is irrigated, the ORIBAS algorithm needs to be modified to better handle these differences. The very low ORIBAS switchgrass prices for North Dakota and South Dakota are result of the synergistic combination of an assumption of moderately good switchgrass yields 
Table 12. Short Rotation Woody Crops - Northern Plains Region

\begin{tabular}{|c|c|c|c|c|c|c|c|c|c|}
\hline SRWC & $\begin{array}{l}\text { Average } \\
\text { yield } \\
\text { (tonlacre/vr) }\end{array}$ & $\begin{array}{l}\text { ORECCL } \\
\text { Average } \\
\text { farmgate } \\
\text { price } \\
\text { [\$ltont }\end{array}$ & $\begin{array}{l}\text { Acreage of } \\
\text { cropland } \\
\text { suitable for } \\
\text { SRWC } \\
\text { (OCO) }\end{array}$ & $\begin{array}{l}\text { ORECCL } \\
\text { Acreage of } \\
\text { tand with } \\
\text { farmgate } \\
\text { price }<\$ 35 \\
\text { (000) }\end{array}$ & $\begin{array}{l}\text { OAECCL } \\
\text { Acreage of } \\
\text { land with } \\
\text { farmgate } \\
\text { price }<\$ 40 \\
(000)\end{array}$ & $\begin{array}{l}\text { ORECCL } \\
\text { Acreage of } \\
\text { land with } \\
\text { farmgate } \\
\text { price }<\$ 45 \\
\text { (000) }\end{array}$ & $\begin{array}{l}\text { ORECCL } \\
\text { Acresge of } \\
\text { land with } \\
\text { farmigate } \\
\text { price }<\$ 50 \\
(000)\end{array}$ & $\begin{array}{l}\text { ORECCL } \\
\text { Average } \\
\text { cash rent } \\
\text { \$lacre/ynt }\end{array}$ & $\begin{array}{l}\text { Number } \\
\text { of } \\
\text { counties }\end{array}$ \\
\hline Kansas & 4.52 & $\$ 54.64$ & 4,587 & 0 & 0 & 0 & 0 & $\$ 42.92$ & 29 \\
\hline Nebraska & 4.52 & $\$ 67.15$ & 6,424 & 0 & 0 & 0 & 0 & $\$ 89.25$ & 29 \\
\hline North Dakota & 3.76 & $\$ 62.21$ & 15,676 & 0 & 0 & 0 & 0 & $\$ 41.69$ & 29 \\
\hline \multirow[t]{2}{*}{ South Dakota } & 4.32 & $\$ 61.58$ & 7,371 & 0 & 0 & 0 & 0 & $\$ 68.14$ & 24 \\
\hline & & $\$ 61.98$ & 34.058 & 0 & 0 & 0 & 0 & $\$ 54.82$ & 111 \\
\hline
\end{tabular}

Table 13. Switchgrass - Northern Plains Region

\begin{tabular}{|c|c|c|c|c|c|c|c|c|c|c|c|c|}
\hline SWG & $\begin{array}{l}\text { Average } \\
\text { yield } \\
\text { (toriacre/yr) }\end{array}$ & $\begin{array}{l}\text { ORECCL } \\
\text { Average } \\
\text { farngate } \\
\text { price } \\
\text { (\$Itor) }\end{array}$ & $\begin{array}{l}\text { Acreage of } \\
\text { cropland } \\
\text { stitable for } \\
\text { SWG ((ODOD) }\end{array}$ & $\begin{array}{c}\text { ORECCL } \\
\text { Acraage of } \\
\text { land with } \\
\text { farmgate } \\
\text { price }<\$ 30 \\
\text { (BOD) }\end{array}$ & $\begin{array}{l}\text { OARECCL } \\
\text { Acreage of } \\
\text { tand with } \\
\text { farmgate } \\
\text { price < } \$ 35 \\
\text { (000) }\end{array}$ & $\begin{array}{l}\text { ORECCl } \\
\text { Acreage of } \\
\text { land with } \\
\text { larmgate } \\
\text { price }<\$ 40 \\
\{000 \mid\end{array}$ & $\begin{array}{l}\text { OAECC: } \\
\text { Acreage of } \\
\text { land with } \\
\text { larmgate } \\
\text { price }<\$ 45 \\
(000)\end{array}$ & $\begin{array}{l}\text { ORECCL } \\
\text { Auerage } \\
\text { cash rent } \\
\text { \$Jacrelyr) }\end{array}$ & $\begin{array}{l}\text { Number } \\
\text { of } \\
\text { counties }\end{array}$ & $\begin{array}{l}\text { ORIBAS } \\
\text { Average } \\
\text { land rent } \\
\text { Slacrelyr) }\end{array}$ & $\begin{array}{l}\text { ORiBAS } \\
\text { Average } \\
\text { farnigate } \\
\text { price } \\
\text { Stiton }\end{array}$ & $\begin{array}{l}\text { Farmgate } \\
\text { price } \\
\text { difference } \\
\text { ORIBAS. } \\
\text { ORECCL. }\end{array}$ \\
\hline Kansas & 5.04 & $\$ 35.24$ & 18,595 & 39 & 9,258 & 17,616 & 18,503 & $\$ 35.75$ & 79 & & & \\
\hline Nebraska & 5.41 & $\$ 45.42$ & 13,709 & 0 & 471 & 3.726 & 7,208 & $\$ 83.69$ & 61 & $\$ 112.21$ & $\$ 50.37$ & $\$ 4.95$ \\
\hline North Dakota & 4.39 & $\$ 38.57$ & 19,970 & 0 & 2,006 & 15,830 & 16,498 & $\$ 38.52$ & 37 & $\$ 3.23$ & $\$ 25.30$ & $(\$ 13.27)$ \\
\hline \multirow[t]{2}{*}{ South Dakoto } & 5.09 & $\$ 38.42$ & 12,642 & 0 & 1,737 & 9,292 & 11,592 & $\$ 49.13$ & 43 & $\$ 4.26$ & $\$ 26.17$ & (\$12.25) \\
\hline & & $\$ 39.03$ & 64.916 & 30 & 13,470 & 46,464 & 53,801 & $\$ 49.33$ & 220 & & & \\
\hline
\end{tabular}

( $\sim 4.5$ to 5 dry tons/acre/yr), low yields on conventional crops, and very high cropland density.

At 110,000 dry ton/yr facility demand, ORIBAS identified 139 sites in Nebraska whose marginal delivered switchgrass feedstock price was $\$ 42.05$ to $\$ 53.13 /$ dry ton with most sites strongly skewed towards the higher end of the price range (Fig. 19). Low cost sites were concentrated along the western edge of the eastern third of the state, in particular in the counties south of the town of Lincoln and counties west of the town of Norfolk, Nebraska. At a 700,000 dry ton/yr facility demand ORIBAS identified 22 sites whose marginal delivered switchgrass feedstock price ranged from $\$ 46.46$ to $\$ 57.50$ (Fig. 20). The spatial pattern of site locations and price was the same as for the smaller facilities.

At 110,000 dry ton/yr facility demand, ORIBAS identified 153 sites in North Dakota whose marginal delivered switchgrass feedstock price was $\$ 28.55$ to $\$ 30.22 /$ dry ton (Fig. 21). Sites were fairly evenly distributed across the region of North Dakota capable of producing switchgrass. (See Fig. 1 for the region boundaries). At a 700,000 dry ton/yr facility demand ORIBAS identified 24 sites whose marginal delivered switchgrass feedstock price ranged from $\$ 30.86$ to $\$ 33.60$ (Fig. 22). The spatial pattern of site locations and price was the same as for the smaller facilities. 


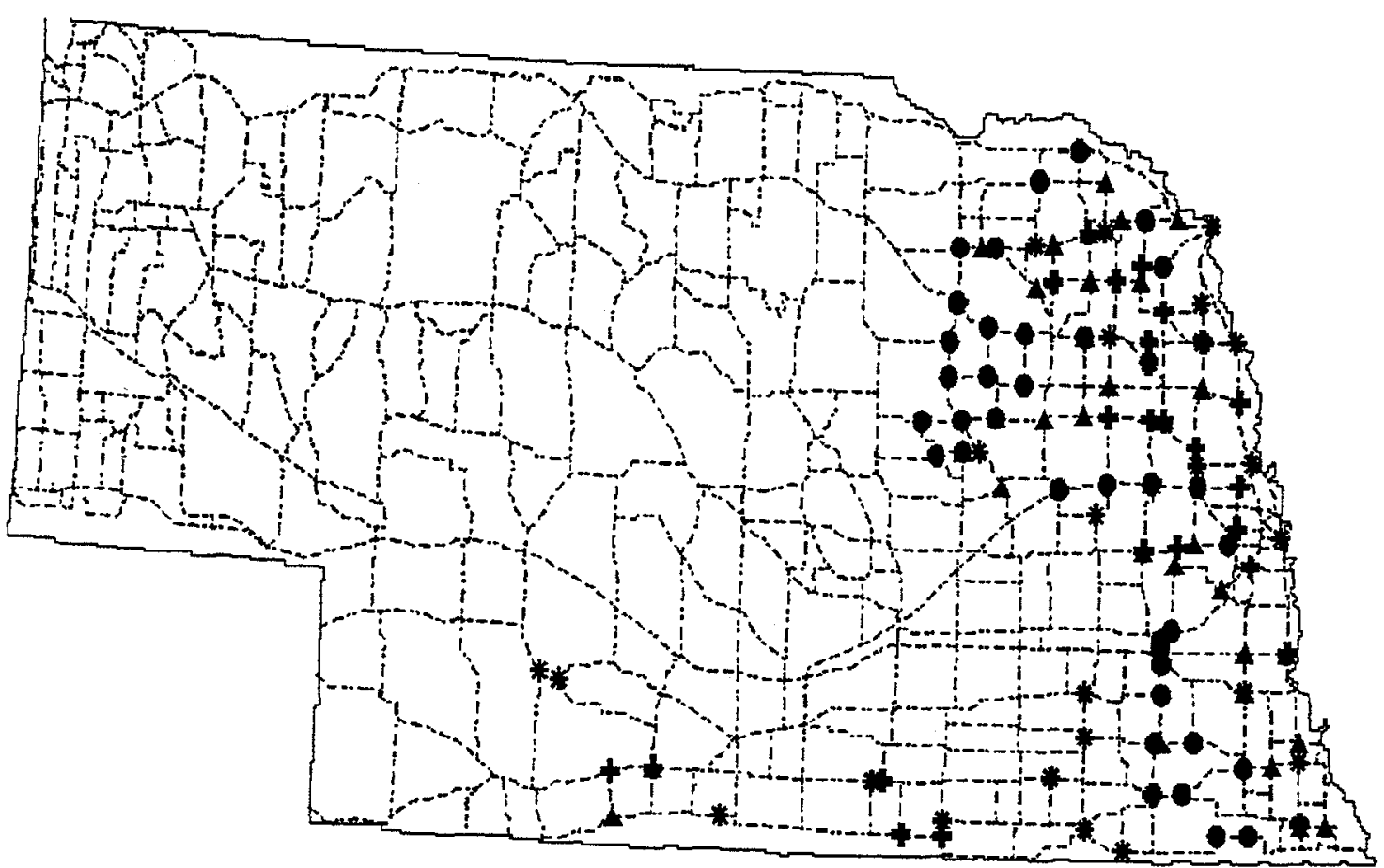

Nebraska $\$ /$ dry ton

- $\$ 42.05-46.22$

- $\$ 46.23-47.94$

$+\$ 47.95-49.74$

$* \$ 49.75-53.13$

Fig. 19. Location and marginal delivered switchgrass price of lowest cost 110,000 ton/yr facility sites in Nebraska. 


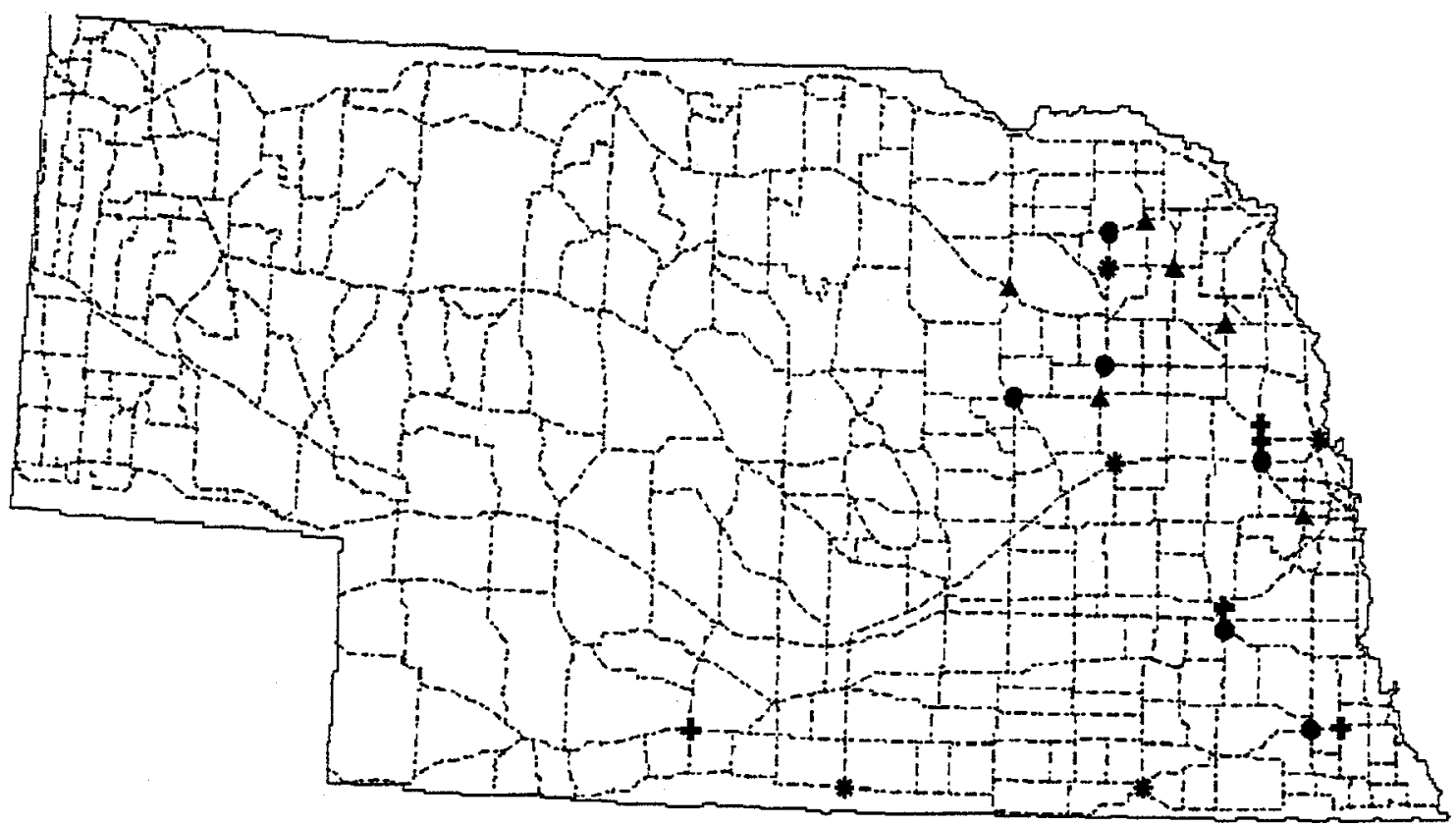

\section{Nebraska $\$ / d r y$ ton}

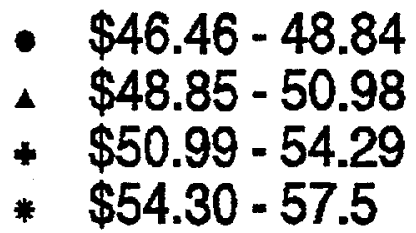

Fig. 20. Location and marginal delivered switchgrass price of lowest cost $\mathbf{7 0 0 , 0 0 0}$ ton/yr facility sites in Nebraska. 


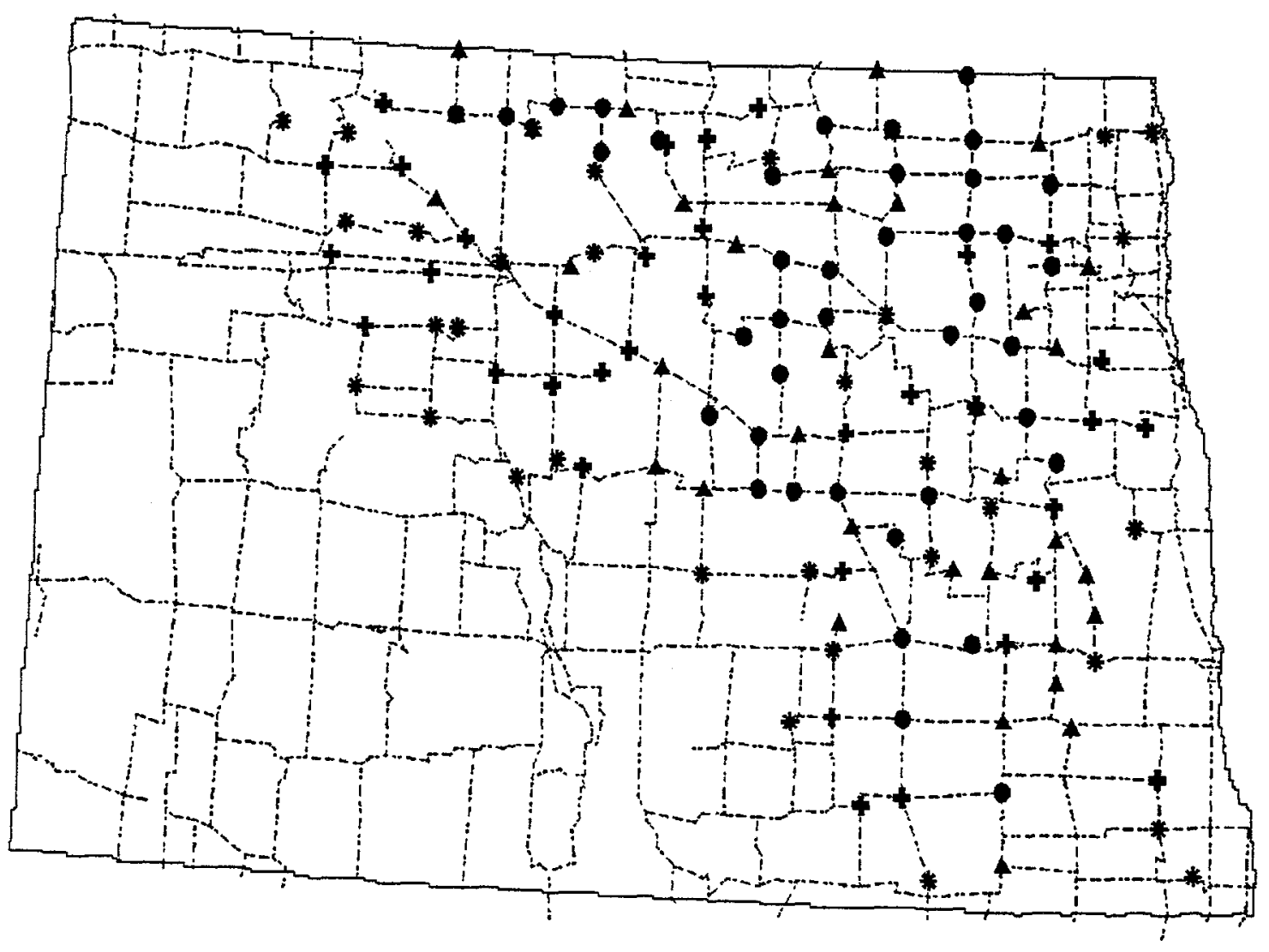

\section{North Dakota $\$ /$ dry ton}

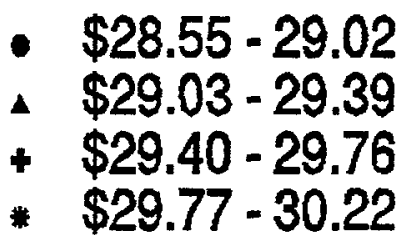

Fig. 21. Location and marginal delivered switchgrass price of lowest cost 110,000 ton/yr facility sites in North Dakota. 


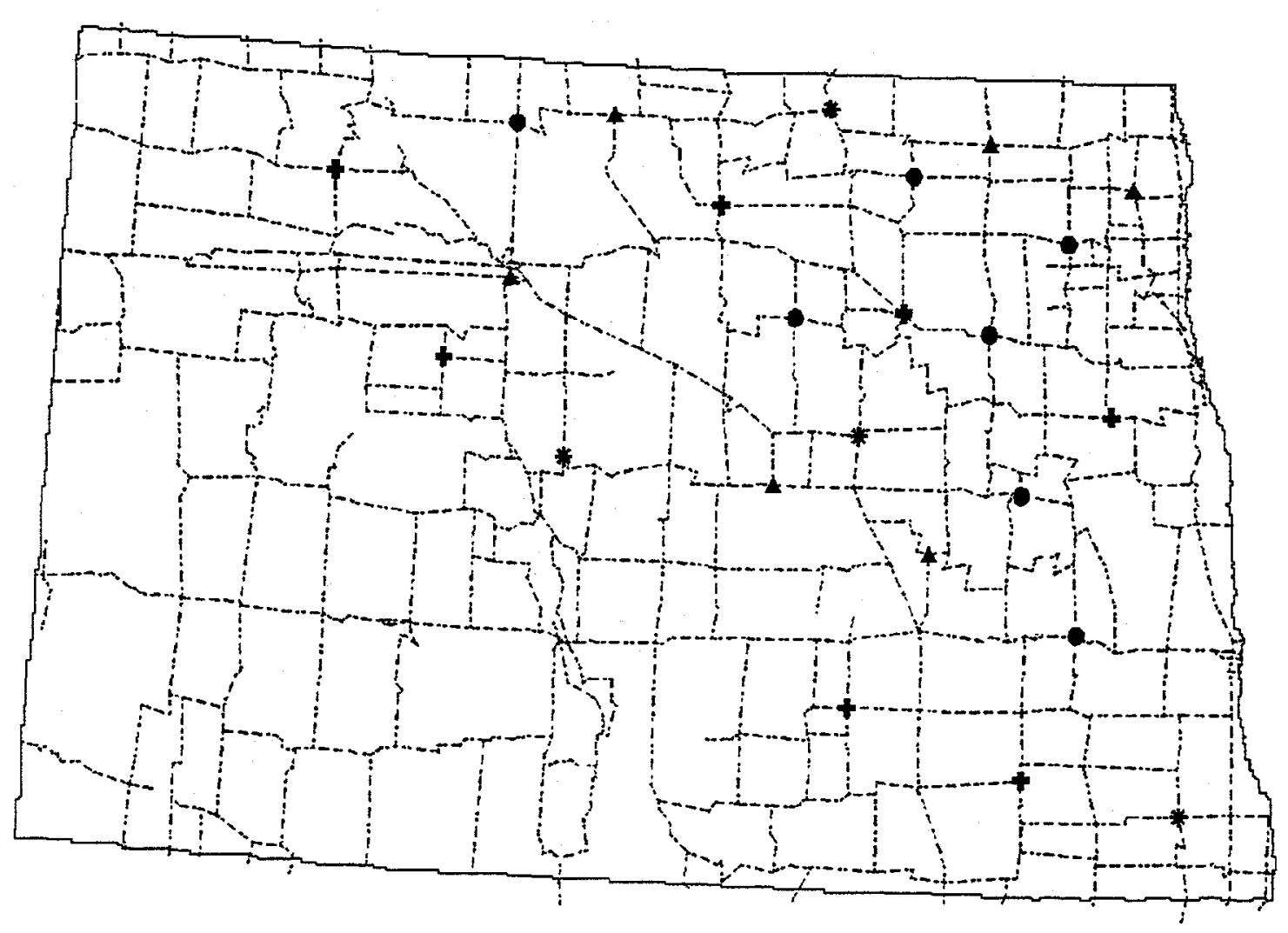

\section{North Dakota $\$ /$ dry ton}

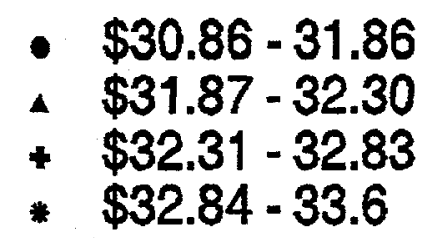

Fig. 22. Location and marginal delivered switchgrass price of lowest cost 700,000 ton/yr facility sites in North Dakota. 


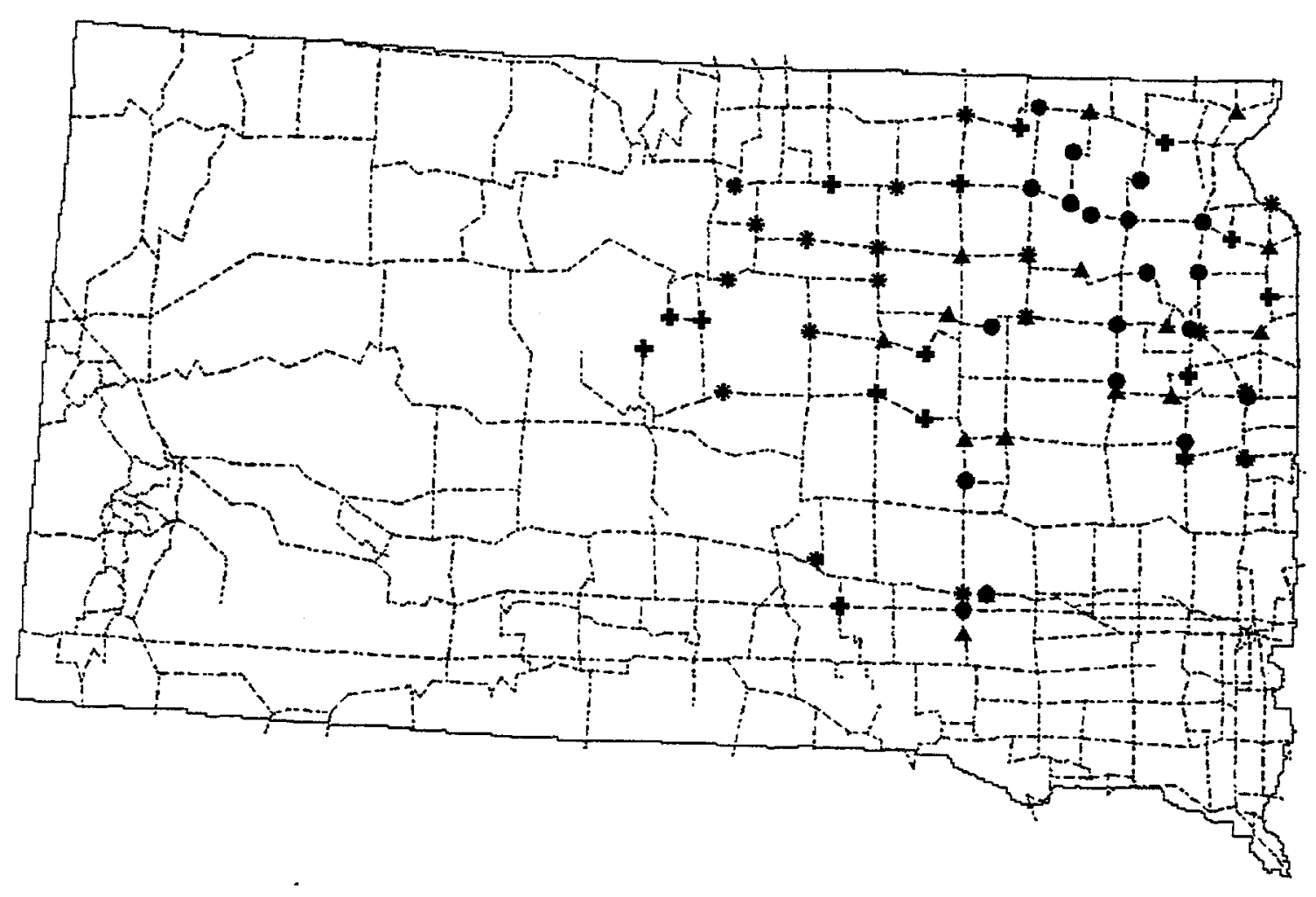

\section{South Dakota $\$ / d r y$ ton}

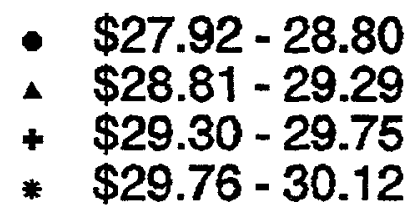

Fig. 23. Location and marginal delivered switchgrass price of lowest cost 110,000 ton/yr facility sites in South Dakota. 


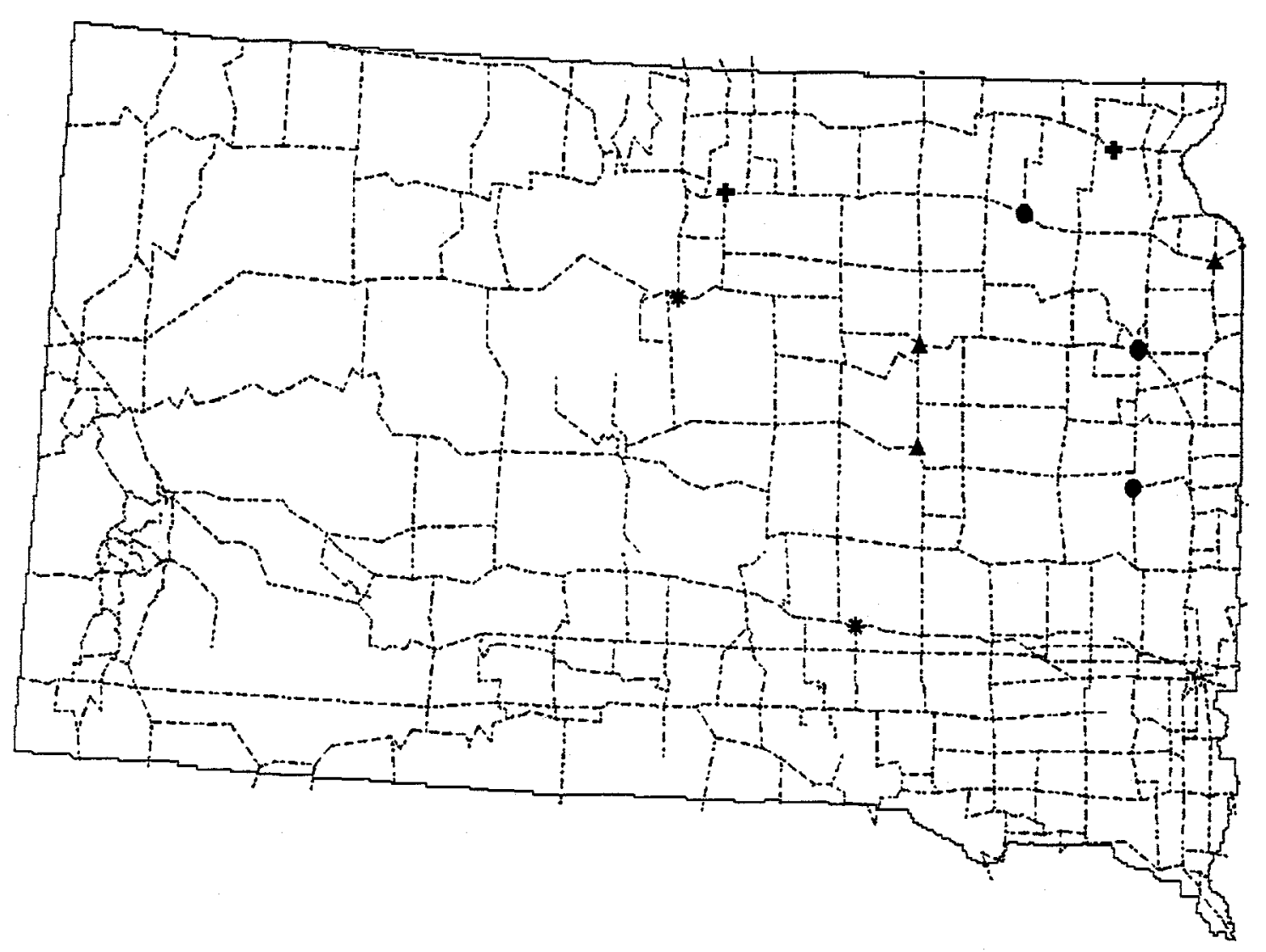

\section{South Dakota $\$ /$ dry ton}

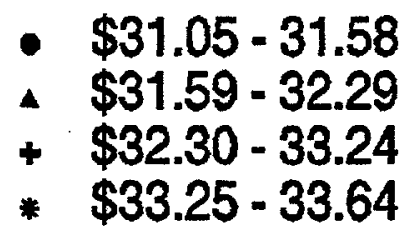

Fig. 24. Location and marginal delivered switchgrass price of lowest cost 700,000 ton/yr facility sites in South Dakota. 
At 110,000 dry ton/yr facility demand, ORIBAS identified 74 sites in South Dakota whose marginal delivered switchgrass feedstock price was $\$ 27.95$ to $\$ 30.12$ /dry ton (Fig. 23). Sites were fairly evenly distributed across the region of South Dakota capable of producing switchgrass. (See Fig. 1 for the region boundaries). The low cost facilities tended to be located in the eastern portion of that region. At a 700,000 dry ton/yr facility demand ORIBAS identified 11 sites whose marginal delivered switchgrass feedstock price ranged from $\$ 31.05$ to $\$ 33.64$ (Fig. 24). The spatial pattern of site locations and price was the same as for the smaller facilities.

\section{PACIFIC NORTHWEST REGION (Hybrid Poplar Only)}

While this region (Fig. 25) has the highest hybrid poplar yields in the United States and these yields are relatively well supported by field studies, the combination of low cropland densities and high farmland values due to development pressures and specialty crops (flowers, seed, mint) makes this region less ideal than might otherwise be expected. Within the region, unirrigated poplar production is restricted to lands west of the Cascade Mountains. The ORECCL estimates of return to lands and management needed in this region are in excess of $\$ 200 /$ acre. A more in-depth examination of the Willamette Valley (the major cropland area in the region) suggested that returns to lands and management of $\$ 65 /$ acre would be competitive (Withrow-Robinson et al. 1995). If that were the case, the farmgate price drops to $\$ 44$ to $\$ 49 /$ dry ton.

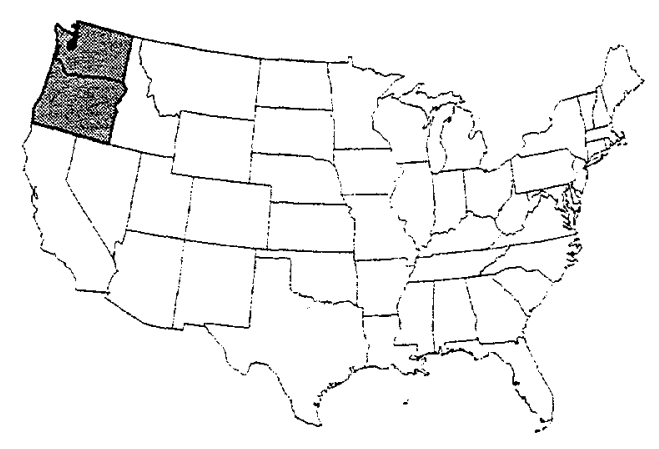

Fig. 25. Pacific Northwest Region

Table 14. Short Rotation Woody Crops - Pacific Northwest

\begin{tabular}{|c|c|c|c|c|c|c|c|c|c|}
\hline SRWC & $\begin{array}{l}\text { Avarage } \\
\text { vieid } \\
\text { [tonjacre/yr) }\end{array}$ & $\begin{array}{l}\text { ORECCL } \\
\text { Average } \\
\text { farmigate } \\
\text { price } \\
\text { (stont }\end{array}$ & $\begin{array}{l}\text { Acreage of } \\
\text { croptand } \\
\text { suitable for } \\
\text { SWG llocol }\end{array}$ & $\begin{array}{c}\text { ORECCL } \\
\text { Acreage of } \\
\text { land with } \\
\text { fammate } \\
\text { price }<\$ 35 \\
(000)\end{array}$ & $\begin{array}{l}\text { ORECCL } \\
\text { Acreage of } \\
\text { land with } \\
\text { farmgate } \\
\text { price }<\$ 40 \\
\text { (000) }\end{array}$ & $\begin{array}{l}\text { DRECCL } \\
\text { Acreage of } \\
\text { land with } \\
\text { farmote } \\
\text { price }<\$ 45 \\
(000)\end{array}$ & $\begin{array}{l}\text { ORECCL } \\
\text { Acreage of } \\
\text { land with } \\
\text { tarmgats } \\
\text { price }<\$ 50 \\
(000)\end{array}$ & $\begin{array}{l}\text { ORECCLL } \\
\text { Average } \\
\text { cash rent } \\
\text { Siacrefyr) }\end{array}$ & $\begin{array}{l}\text { Number } \\
\text { of } \\
\text { counties }\end{array}$ \\
\hline Oregan & 6.03 & $\$ 79.68$ & 991 & 0 & 0 & 0 & 0 & $\$ 217.14$ & 16 \\
\hline \multirow[t]{2}{*}{ Wastington } & 5.90 & $\$ 86.13$ & 283 & 0 & 0 & 0 & 0 & $\$ 243.74$ & 19 \\
\hline & & $\$ 81.11$ & 1.274 & 0 & 0 & 0 & 0 & $\$ 223.05$ & 35 \\
\hline
\end{tabular}




\section{SOUTHEAST REGION}

Cropland in the upper Coastal Plain and lower Piedmont portions of the region (Fig. 26) appears well suited for energy crops, in particular switchgrass (Tables 15 and 16). Cash land rents are low; yields are moderately high. The field data on switchgrass yields are comparatively rich for this region. Farmgate prices under $\$ 35 /$ dry ton seem possible for most cropland. The drawback to the region is its comparatively low density of cropland which would raise transportation costs. If mature yields of 6 dry tons/yr could also be achieved on cropland that is currently being used for pasture, the density of land suitable for switchgrass production would double. Nonetheless, the region should be capable of supplying several million tons of biomass annually using the current cropland.

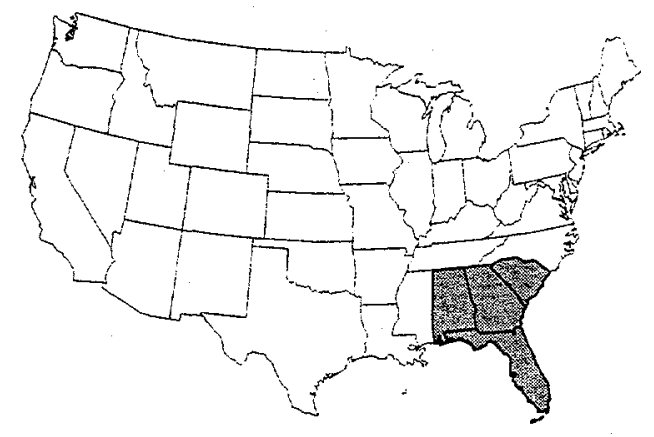

Fig. 26. Southeast Region.

This was also one of the lowest cost production regions for hybrid poplar with substantial acreages with prices under $\$ 50 /$ dry ton. Given the strong wood products industry in the region, the infrastructure for handling wood should be available. There is also considerable interest in hybrid poplar production by the wood products industry in this region.

\section{ORIBAS Analysis - Alabama, Florida, Georgia, South Carolina}

All four states in this region have been analyzed using ORIBAS. The results largely corroborate the ORECCL analysis. The ORIBAS analysis, which is not biased by real estate development pressures (e.g., as near Atlanta and Athens, Georgia), suggests that the upper Piedmont of Georgia would also be a good region for switchgrass production. Transportation costs were estimated to be about $\$ 8 /$ dry ton for large facilities ( $>700,000$ tons/yr) and around $\$ 6 /$ dry ton for moderate-sized facilities $(110,000$ tons/yr). The much lower average farmgate prices for Florida are due to differences in the land area considered. The ORIBAS analyses only considered counties which produced at least some corn and, thereby, excluded the high-priced countries around Gainesville and Ocala and the Gulf Coast counties. 
Table 15. Short Rotation Woody Crops - Southeast Region

\begin{tabular}{|c|c|c|c|c|c|c|c|c|c|}
\hline SRWC & $\begin{array}{l}\text { Average } \\
\text { yield } \\
\text { (tondacralyr) }\end{array}$ & $\begin{array}{l}\text { ORECCL } \\
\text { Average } \\
\text { tarmgate } \\
\text { prick } \\
\text { (s/ton) }\end{array}$ & $\begin{array}{l}\text { Acreage of } \\
\text { cropland } \\
\text { suitable for } \\
\text { SRWC } \\
(000)\end{array}$ & $\begin{array}{c}\text { OfECCCL } \\
\text { Acreage of } \\
\text { land with } \\
\text { farmgate } \\
\text { price }<\$ 35 \\
\text { (000) }\end{array}$ & $\begin{array}{l}\text { ORECCL } \\
\text { Acrtage of } \\
\text { land with } \\
\text { farmgate } \\
\text { price }<\$ 40 \\
\text { (000) }\end{array}$ & $\begin{array}{l}\text { ORECCL } \\
\text { Acreoge of } \\
\text { land with } \\
\text { farmigate } \\
\text { grice }<\$ 45 \\
(000)\end{array}$ & $\begin{array}{l}\text { ORECCL } \\
\text { Acreage of } \\
\text { land with } \\
\text { farmgate } \\
\text { price }<\$ 50 \\
(000)\end{array}$ & $\begin{array}{l}\text { ORECCL } \\
\text { Average } \\
\text { cass rent } \\
\text { s/acre/yr) }\end{array}$ & $\begin{array}{l}\text { Number } \\
\text { of } \\
\text { counties }\end{array}$ \\
\hline Alabama & 4.51 & $\$ 51.35$ & 2,643 & 0 & 0 & 0 & 1,158 & $\$ 32.50$ & 67 \\
\hline Florida & 4.50 & $\$ 56.91$ & 582 & 0 & 0 & 0 & 0 & $\$ 52.30$ & 29 \\
\hline Georgia & 4.44 & $\$ 50.39$ & 4,403 & 0 & 0 & 0 & 3,029 & $\$ 26.65$ & 159 \\
\hline \multirow[t]{2}{*}{ South Caroina } & 4.39 & $\$ 48.99$ & 2,000 & 0 & 0 & 0 & 1,454 & $\$ 20.76$ & 46 \\
\hline & & $\$ 50.77$ & 9,268 & 0 & 0 & 0 & 5.641 & $\$ 28.66$ & 301 \\
\hline
\end{tabular}

Table 16. Switchgrass - Southeast Region

\begin{tabular}{|c|c|c|c|c|c|c|c|c|c|c|c|c|}
\hline SWG & $\begin{array}{l}\text { Average } \\
\text { yield } \\
\text { (ton/acre/yr) }\end{array}$ & $\begin{array}{l}\text { CRECCL } \\
\text { Average } \\
\text { farmgate } \\
\text { price } \\
\text { (shon) }\end{array}$ & $\begin{array}{l}\text { Acreage of } \\
\text { cropland } \\
\text { stitable for } \\
\text { SWG (fooO) }\end{array}$ & $\begin{array}{c}\text { ORECCL } \\
\text { Acreage of } \\
\text { land with } \\
\text { farmagate } \\
\text { price }<\$ 30 \\
\text { (000) }\end{array}$ & $\begin{array}{l}\text { ORECCLL } \\
\text { Acreage of } \\
\text { land with } \\
\text { farmgate } \\
\text { price }<\$ 35 \\
(000)\end{array}$ & $\begin{array}{l}\text { ORECCL } \\
\text { Acreage of } \\
\text { land with } \\
\text { farmgate } \\
\text { price }<\$ 40 \\
(000)\end{array}$ & $\begin{array}{l}\text { ORECCLL } \\
\text { Acreage of } \\
\text { land with } \\
\text { farmgate } \\
\text { price }<\$ 45 \\
(000)\end{array}$ & $\begin{array}{l}\text { ORECCL } \\
\text { Averagga } \\
\text { cash sent } \\
\text { \$lactef(yr) }\end{array}$ & $\begin{array}{l}\text { Number } \\
\text { of } \\
\text { countiess }\end{array}$ & $\begin{array}{l}\text { ORIBAS } \\
\text { Average } \\
\text { land rent } \\
\text { S/acref(y) }\end{array}$ & $\begin{array}{l}\text { ORiBas } \\
\text { Average } \\
\text { farmagte } \\
\text { price } \\
\text { s/ton }\end{array}$ & $\begin{array}{l}\text { Farngate } \\
\text { price } \\
\text { difference } \\
\text { OAIBAS- } \\
\text { ORECCI }\end{array}$ \\
\hline Alabama & 6.19 & $\$ 31.44$ & 2,643 & 796 & 2.454 & 2,634 & 2,643 & $\$ 32.50$ & 67 & $\$ 3.93$ & $\$ 24.75$ & $(\$ 6.69)$ \\
\hline Florida & 4.78 & $\$ 49.24$ & 761 & 0 & 223 & 358 & 445 & $\$ 64.98$ & 36 & $\$ 19.85$ & $\$ 25.98$ & $(\$ 23.26)$ \\
\hline Geargig & 5.82 & $\$ 31.52$ & 4,403 & 1.957 & 3,580 & 3,700 & 3,968 & $\$ 26.65$ & 159 & $\$ 15.78$ & $\$ 28.14$ & $(\$ 3.38)$ \\
\hline \multirow[t]{2}{*}{ South Carolina } & 5.32 & $\$ 32.54$ & 2,000 & 1,225 & 1.528 & 1.544 & 1.874 & $\$ 20.76$ & 46 & $\$ 1.19$ & $\$ 27.27$ & $(\$ 5.27)$ \\
\hline & & $\$ 33.14$ & 9.447 & 3.978 & 7.785 & 8,236 & 8,930 & $\$ 30.13$ & 308 & & & \\
\hline
\end{tabular}

At 110,000 dry ton/yr facility demand, ORIBAS identified 29 sites in Alabama whose marginal delivered switchgrass feedstock price was $\$ 28.08$ to $\$ 31.84 /$ dry ton (Fig. 27). Sites were generally located in the southeast corner of the state and or along the northern tenth of the state. Both are regions of high cropland density. The paucity of sites in the black prairie region is probably due to the lack of active cropland (cropland on which crops are being produced-the only land base considered in these ORIBAS analyses). The northern sites were slightly less expensive. At the 700,000 ton/yr demand level only three sites were located, and prices ranged from $\$ 31.99$ to $\$ 35.94$ (Fig. 28). The geographic distribution of the sites at this facility demand mirrored that of the smaller facilities demand.

At 110,000 dry ton/yr facility demand, ORIBAS identified three sites in Florida whose marginal delivered switchgrass feedstock price was $\$ 35.43$ to $\$ 36.79 /$ dry ton (Fig. 29). The land base for switchgrass in Florida is largely limited to the northern panhandle, and cropland density is fairly low. The state was incapable of supporting a $700,000 \mathrm{dry} /$ year switchgrass facility under the crop land availability assumptions used in the analyses.

At 110,000 dry ton/yr facility demand, ORIBAS identified 30 sites in Georgia whose marginal delivered switchgrass feedstock price was $\$ 30.01$ to $\$ 34.19 /$ dry ton (Fig. 30). The lowest cost sites tended to fall along the southern boundary of the Piedmont region. 


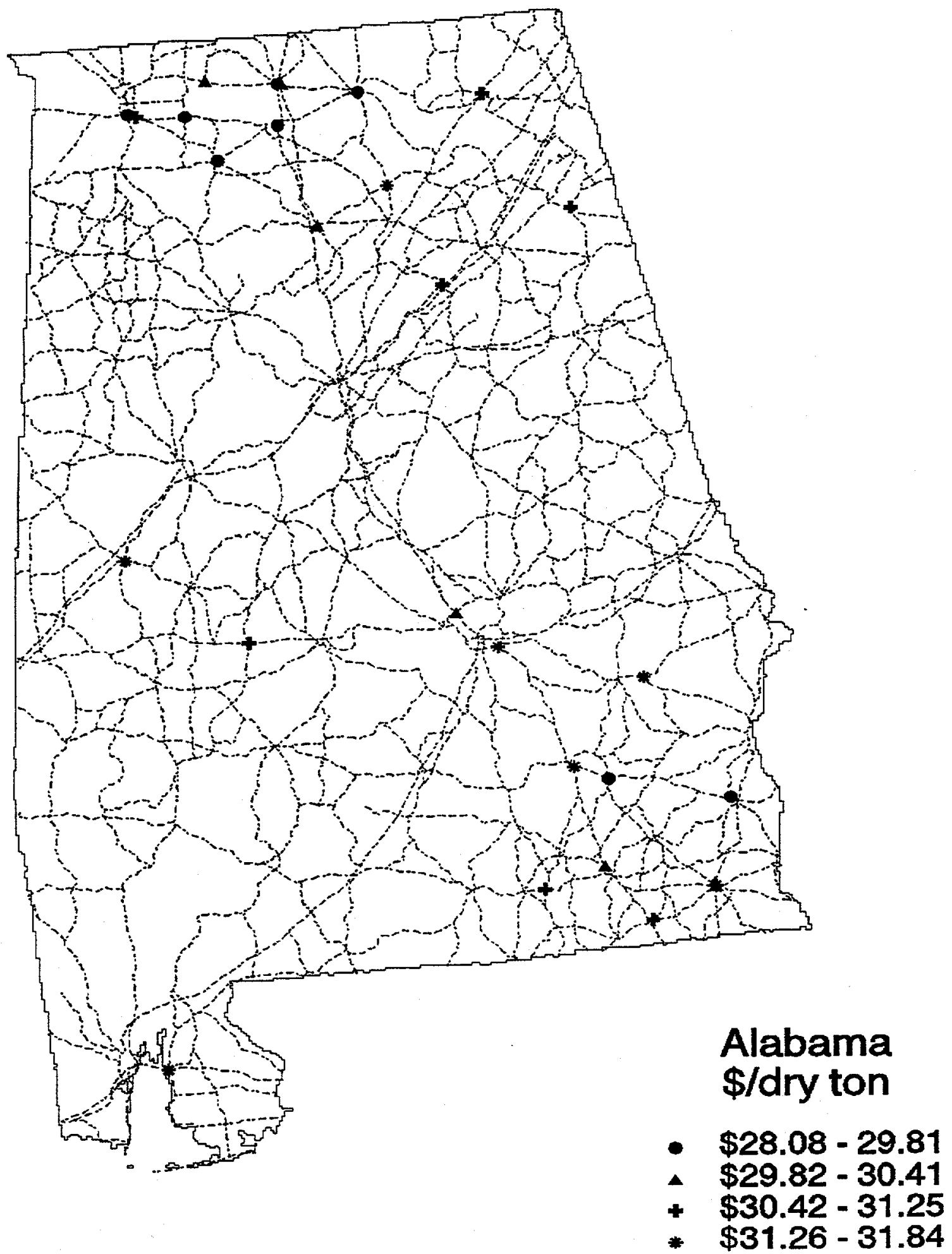

Fig. 27. Location and marginal delivered switchgrass price of lowest cost 110,000 ton/yr facility sites in Alabama. 


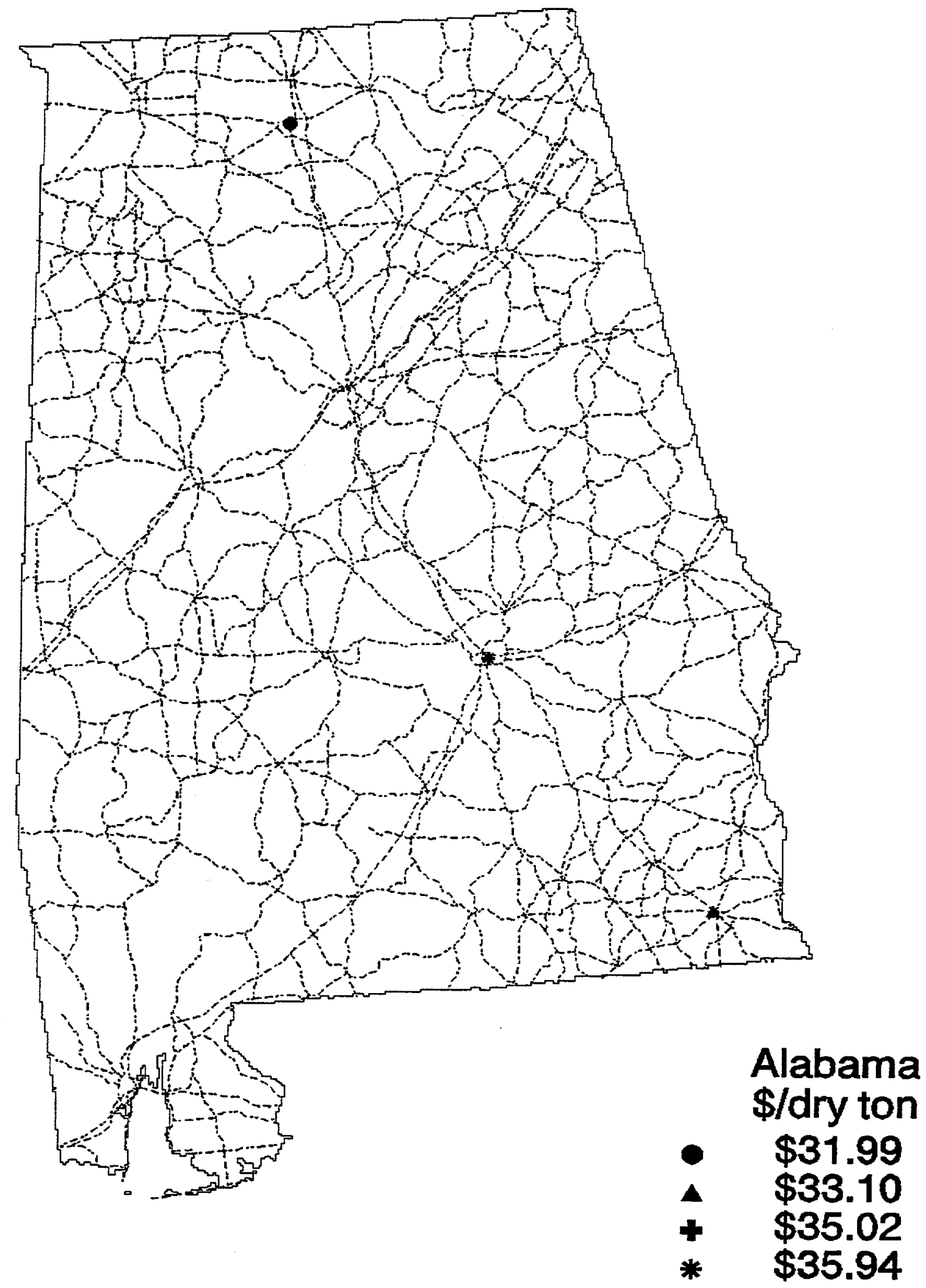

Fig. 28. Location and marginal delivered switchgrass price of lowest cost 700,000 ton/yr facility sites in Alabama. 


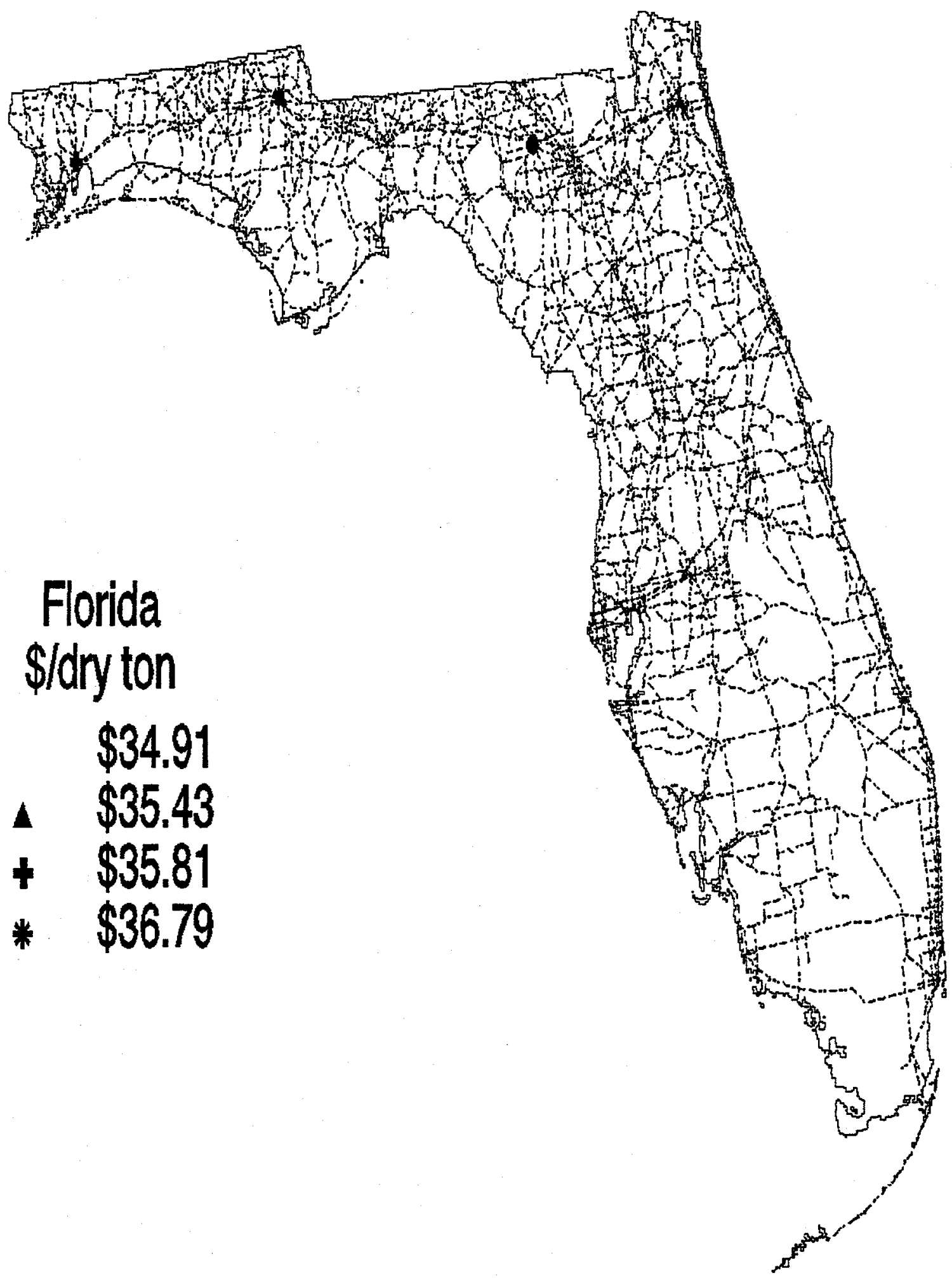

Fig. 29. Location and marginal delivered switchgrass price of lowest cost 110,000 ton/yr facility sites in Florida. 


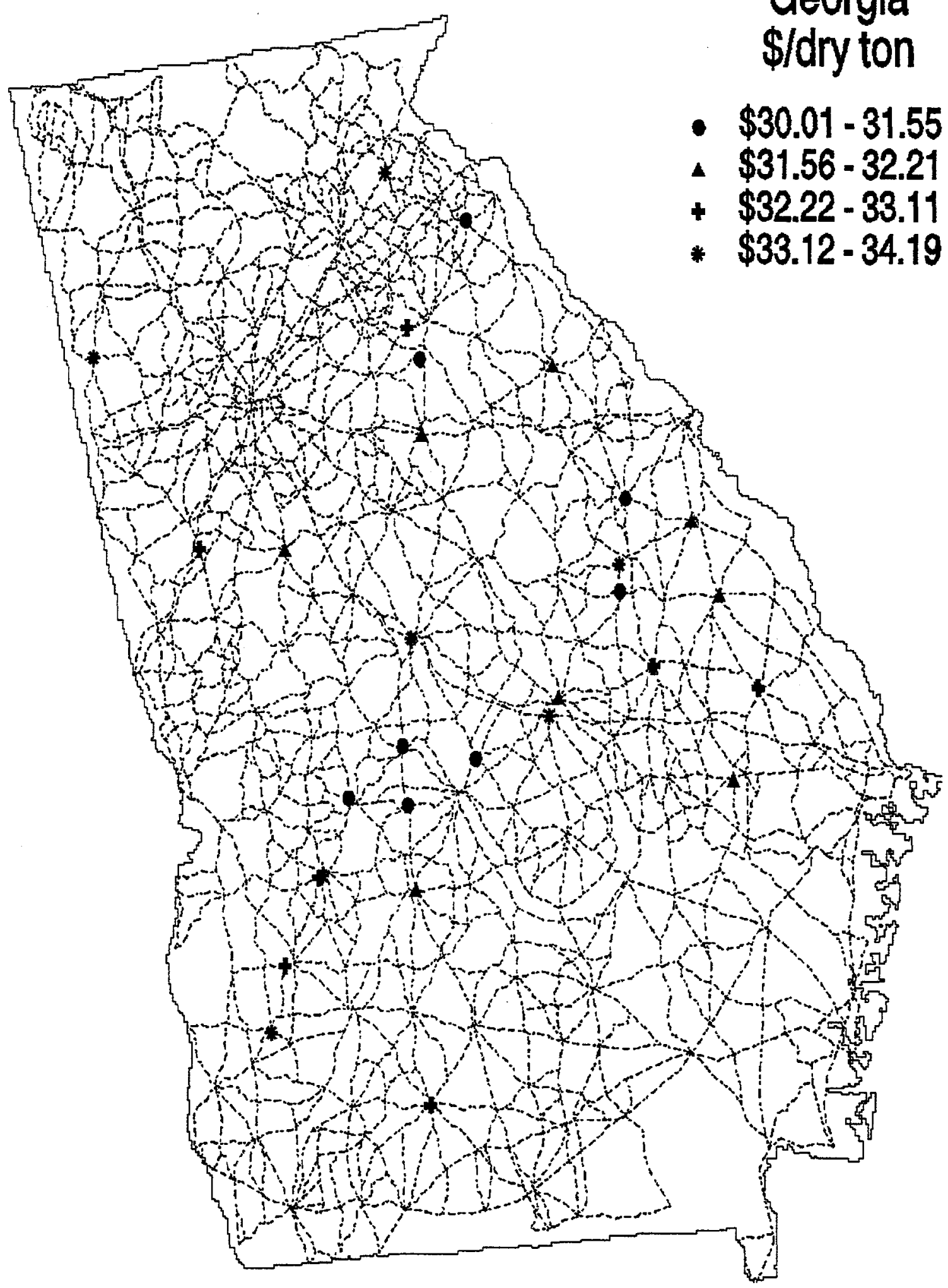

Fig. 30. Location and marginal delivered switchgrass price of lowest cost 110,000 ton/yr facility sites in Georgia. 


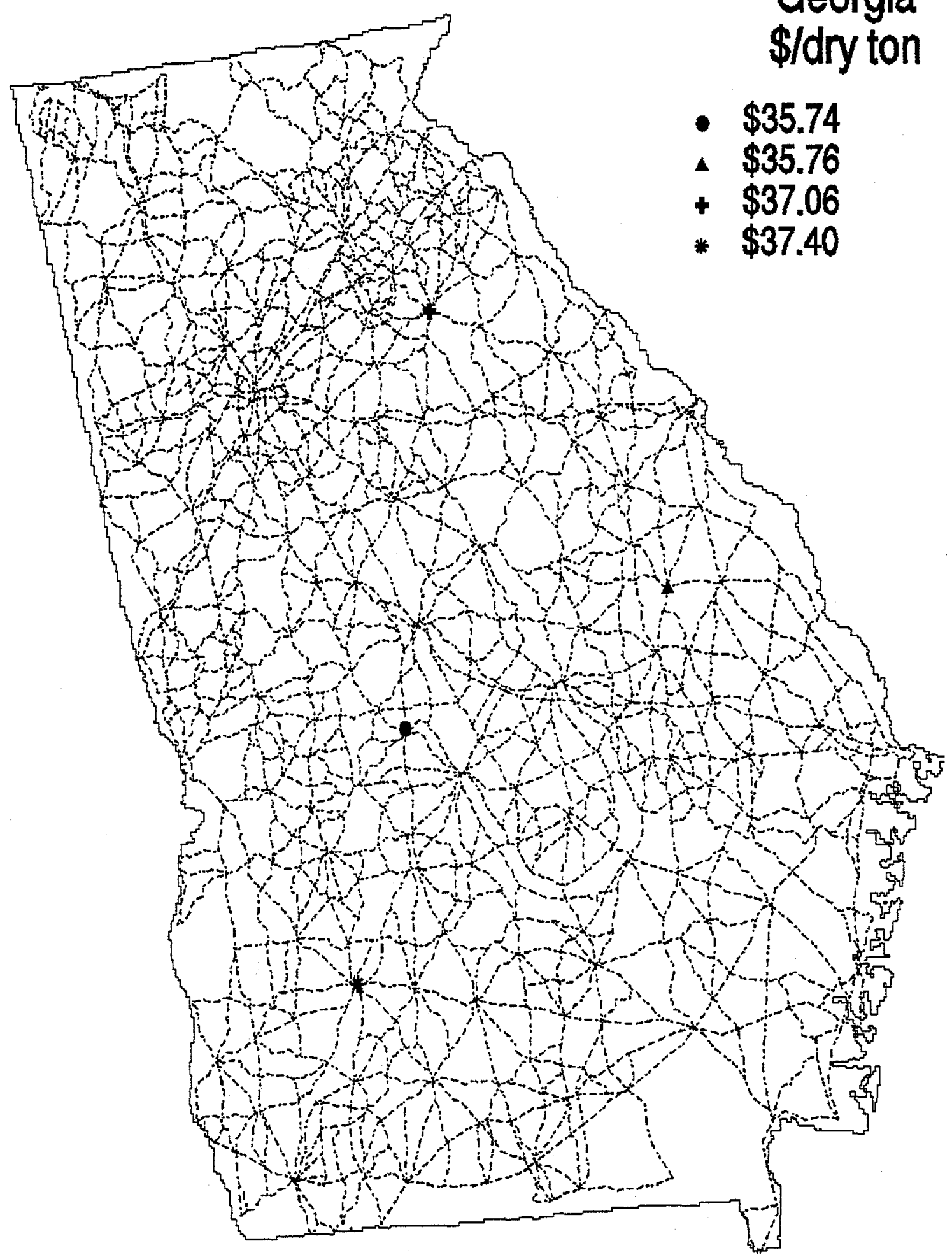

Fig. 31. Location and marginal delivered switchgrass price of lowest cost 700,000 ton/yr facility sites in Georgia. 


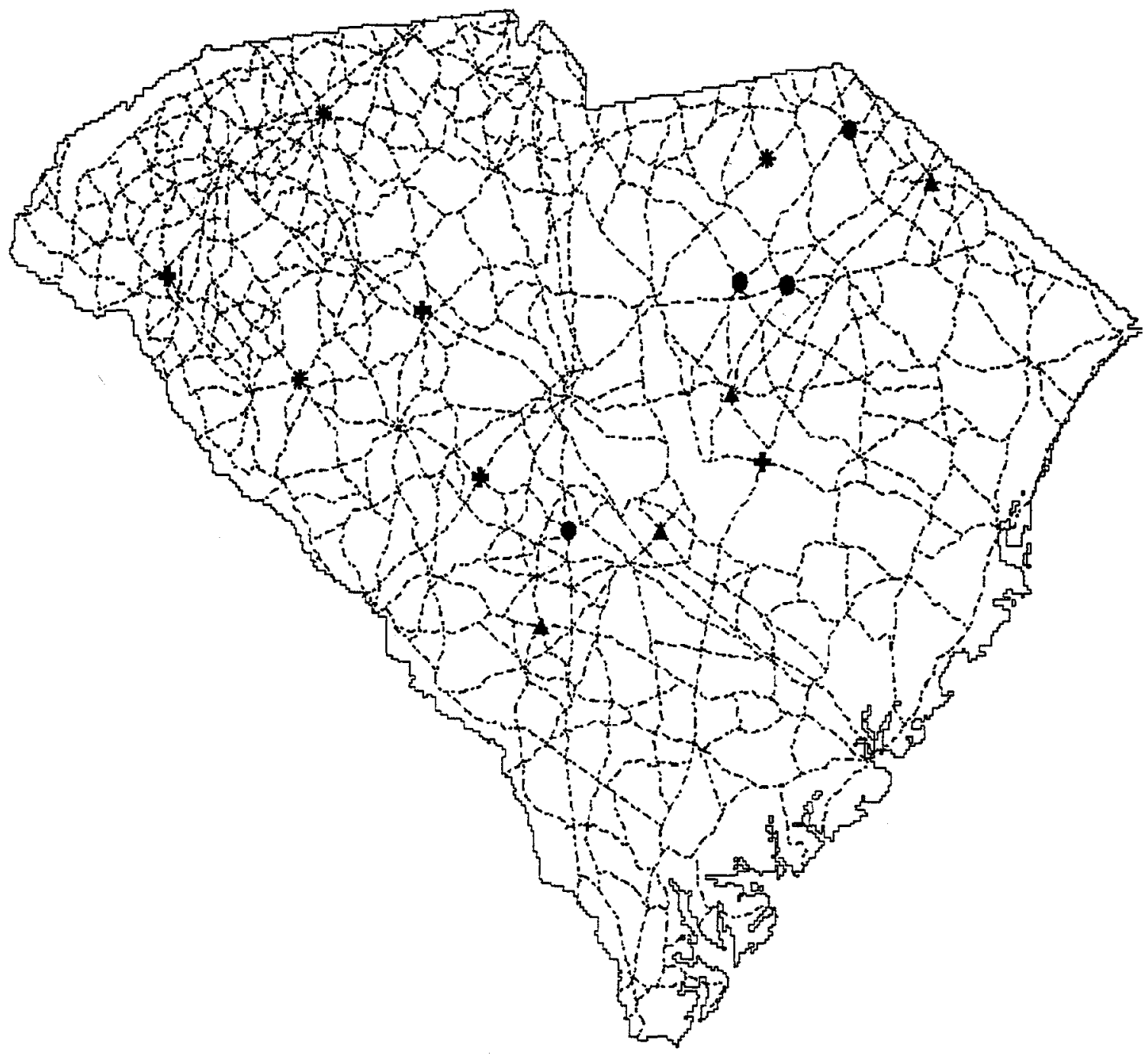

\section{South Carolina $\$ /$ dry ton}

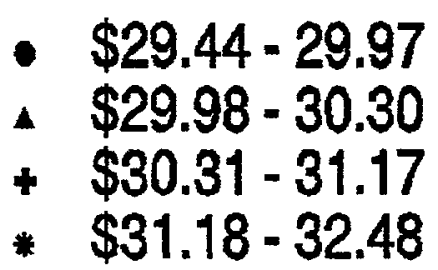

Fig. 32. Location and marginal delivered switchgrass price of lowest cost 110,000 ton/yr facility sites in South Carolina. 


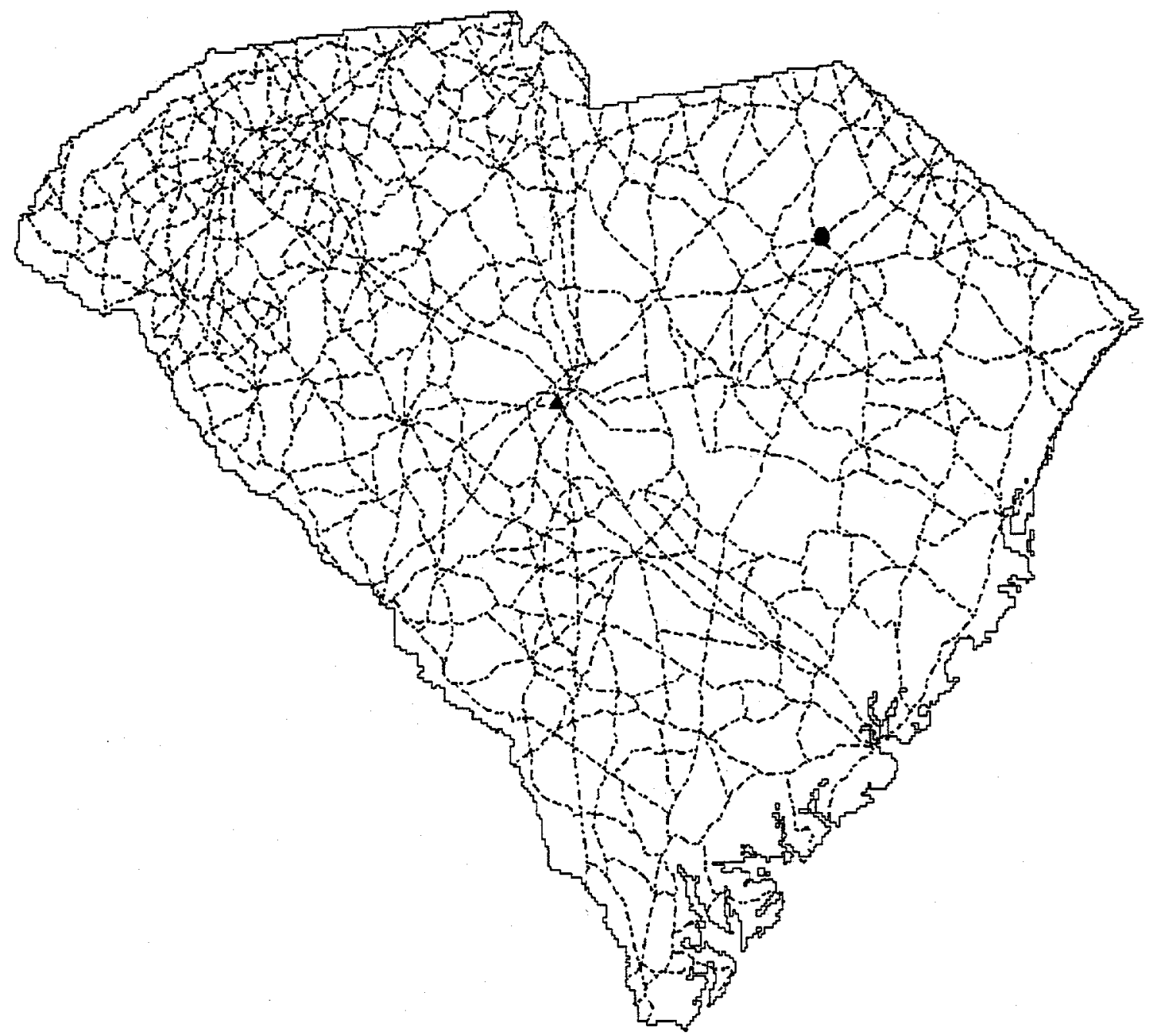

\section{South Carolina \$/dry ton}

\section{- $\$ 34.07$ \\ - $\$ 35.54$}

Fig. 33. Location and marginal delivered switchgrass price of lowest cost 700,000 ton/yr facility sites in South Carolina. 
The lack of facilities in the southeast portion of Georgia is due to low cropland density and the assumption of low switchgrass yields in the coastal plain. The lack of facilities in the northwest corner of the state is due to the profitability of conventional crops. At the 700,000 ton/yr demand level only four sites were located and prices ranged from $\$ 35.74$ to $\$ 37.40$ (Fig. 31). The geographic distribution of the sites at this facility demand mirrored that of the smaller facilities.

At 110,000 dry ton/yr facility demand, ORIBAS identified 15 sites in South Carolina whose marginal delivered switchgrass feedstock price was $\$ 29.44$ to $\$ 32.48 /$ dry ton (Fig. 32). As in Georgia, the lowest cost sites tended to fall along the southern boundary of the Piedmont, and no facilities were sited in the Coastal Plain area due to low cropland density and low switchgrass yields. At the 700,000 ton/yr demand level, only two sites were located at prices of $\$ 34.07$ and $\$ 35.54$ (Fig. 33).

\section{SOUTHERN PLAINS REGION}

Like the Northern Plains, this region (Fig. 34) is too dry in most locations to support high yielding hybrid poplar (Table 17). However, except along the Gulf Coast, this region would appear to hold considerable promise for switchgrass production if consistent yields of 4 to 5 dry tons or more can be achieved (Table 18). Field data from Texas suggest this is possible, but intermittent drought may be problematic, especially in establishing switchgrass stands. Nonetheless, this regions is very promising for largescale production of switchgrass, as yields can be good, cropland density is high, and cash rents are comparatively low.

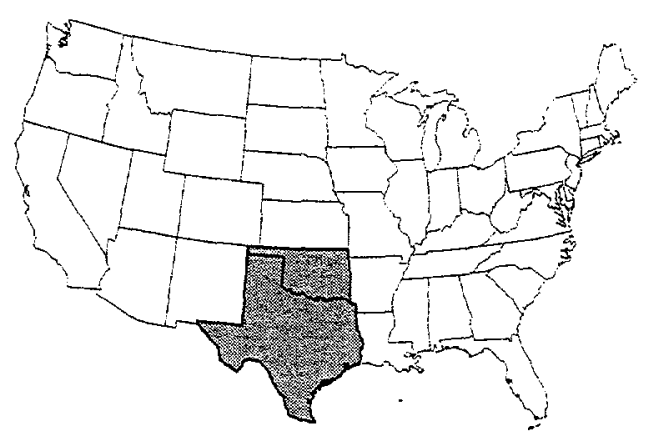

Fig. 34. Southern Plains Region 
Table 17. Short Rotation Woody Crops - Southern Plains Region

\begin{tabular}{|c|c|c|c|c|c|c|c|c|c|}
\hline SAWC & $\begin{array}{l}\text { Average } \\
\text { yiatd } \\
\text { (ton/acrelyr) }\end{array}$ & $\begin{array}{l}\text { ORECCL } \\
\text { Average } \\
\text { farmgate } \\
\text { price } \\
\text { (\$/ton) }\end{array}$ & $\begin{array}{l}\text { Acreage of } \\
\text { cropland } \\
\text { suitable for } \\
\text { SRirc } \\
\text { (|Oo) }\end{array}$ & $\begin{array}{l}\text { OAECCL } \\
\text { Acreage of } \\
\text { land with } \\
\text { farmgate } \\
\text { price }<\$ 35 \\
\text { (000) }\end{array}$ & $\begin{array}{l}\text { ORECCL } \\
\text { Acreage of } \\
\text { land with } \\
\text { fammgate } \\
\text { price }<\$ 40 \\
(000)\end{array}$ & $\begin{array}{l}\text { ORECCL } \\
\text { Acreage of } \\
\text { kand with } \\
\text { farmgate } \\
\text { price }<\$ 45 \\
\text { (000) }\end{array}$ & $\begin{array}{c}\text { ORECCL } \\
\text { Acreage of } \\
\text { land with } \\
\text { tarmgate } \\
\text { price }<\$ 50 \\
(000)\end{array}$ & $\begin{array}{l}\text { ORECCLL } \\
\text { Average } \\
\text { casth rent } \\
\text { Slacrelyr) }\end{array}$ & $\begin{array}{l}\text { Munber } \\
\text { of } \\
\text { counties }\end{array}$ \\
\hline Oklahoma & 4.26 & $\$ 52.42$ & 1,510 & 0 & 0 & 0 & 315 & $\$ 32.00$ & 27 \\
\hline \multirow[t]{2}{*}{ Texas } & 4.01 & $\$ 56.30$ & 991 & 0 & 0 & 0 & 0 & $\$ 39.95$ & 37 \\
\hline & & $\$ 53.95$ & 2.501 & 0 & 0 & 0 & 315 & $\$ 35.15$ & 64 \\
\hline
\end{tabular}

Table 18. Switchgrass - Southern Plains Region

\begin{tabular}{|c|c|c|c|c|c|c|c|c|c|}
\hline SWG & $\begin{array}{l}\text { Average } \\
\text { yieild } \\
\text { (tonfacrelyr) }\end{array}$ & $\begin{array}{l}\text { ORECCL } \\
\text { Average } \\
\text { farmgate } \\
\text { price } \\
\text { [\$|ton] }\end{array}$ & $\begin{array}{l}\text { Acreage of } \\
\text { ctopiand } \\
\text { suitable for } \\
\text { SWG } \\
\lfloor(000)\end{array}$ & $\begin{array}{c}\text { ORECCL } \\
\text { Acreage of } \\
\text { land with } \\
\text { farmgate } \\
\text { price }<\$ 30 \\
(000)\end{array}$ & $\begin{array}{l}\text { ORECCL } \\
\text { Acreage of } \\
\text { land with } \\
\text { farmgate } \\
\text { price }<\$ 35 \\
(000)\end{array}$ & $\begin{array}{l}\text { ORECCL } \\
\text { Acteage of } \\
\text { land with } \\
\text { fanngate } \\
\text { price }<\$ 40 \\
(000)\end{array}$ & $\begin{array}{l}\text { ORECCL } \\
\text { Acreage of } \\
\text { land with } \\
\text { fammgte } \\
\text { price }<\$ 45 \\
(000)\end{array}$ & $\begin{array}{l}\text { ORECCL } \\
\text { Average } \\
\text { cash rent } \\
\text { \$lacrefyr) }\end{array}$ & $\begin{array}{l}\text { Number } \\
\text { of } \\
\text { counties }\end{array}$ \\
\hline Odlahoma & 5.50 & $\$ 35.71$ & 5,360 & 0 & 2,133 & 5,282 & 5,360 & $\$ 32.13$ & 57 \\
\hline \multirow[t]{2}{*}{ Texas } & 5.35 & $\$ 38.40$ & 8,500 & 0 & 3,324 & 5,529 & 7.265 & $\$ 37.32$ & 119 \\
\hline & & $\$ 37.36$ & 13,860 & 0 & 5,457 & 10,911 & 12.625 & $\$ 35.31$ & 176 \\
\hline
\end{tabular}




\section{REFERENCES}

De La Torre Ugarte, D.G. and D.E. Ray. "An overview of the POLYSYS Modeling Framework". Biomass and Bioenergy. In press.

Graham, R.L., B. C. English, C.E. Noon, H.I. Jager and M.J. Daly. 1997a. "Predicting Switchgrass farmgate and delivered costs: An 11-state analysis". Pgs 121-129. Making a business from biomass in energy, environment, chemical, fibers and materials. Proceedings of the 3rd Biomass Conference of the Americas, August 24-28, Montreal, Quebec. R.P. Overend and E. Chornet (eds). Elsevier Science, Inc. NewYork, New York.

Graham, R.L., L.J. Allison and D.A. Becker. 1997b. "ORECCL - Oak Ridge Energy Crop County Level Database". Pgs 121-129. Making a business from biomass in energy, environment, chemical, fibers and materials. Proceedings of the 3rd Biomass Conference of the Americas, August 24-28, Montreal, Quebec. R.P. Overend and E. Chornet (eds). Elsevier Science, Inc. NewYork, New York.

Graham, R.L., L.J. Allison, and D.A. Becker. 1996a. "ORRECL- Oak Ridge Energy Crop County Level Database". Pgs 522-529. Proceedings of Bioenergy '96-The Seventh National Bioenergy Conference, Sept. 15-19, Nashville, Tennessee. Southeastern Regional Biomass Energy Program, Muscle Shoals, AL.

Graham, R.L. , B.C. English, C.E. Noon, W. Liu, M.J. Daly, H.I. Jager. 1996b. "A regional-scale GIS-based modeling system for evaluating the potential costs and supplies of biomass from biomass crops." Pgs 1991-1996. Biomass for Energy and the Environment. Proceedings of the 9th European Bioenergy Conference, June 24-27, 1996, Copenhagen, Denmark. P. Chartier, G.L. Ferrero, U.M. Henius, S. Hultberg, J. Sachau, and M. Wiinblad (eds.) Elsevier Science Ltd. Oxford, Great Britain.

Noon, C.E., M.J. Daly, R.L. Graham, and F.B. Zhan. 1996. "Transportation and site location analysis for Regional Integrated Biomass Assessment (RIBA)". Pgs 487-493. Proceedings of Bioenergy '96--The Seventh National Bioenergy Conference, Sept. 15-19, Nashville, Tennessee. Southeastern Regional Biomass Energy Program, Muscle Shoals, AL. 
Samson, R., P. Girouard, and Y. Chen. 1997. "Evaluation of switchgrass and short rotation forestry willow in eastern Canada as bio-energy and agr-fibre". Pgs 145152. Making a business from biomass in energy, environment, chemical, fibers and materials. Proceedings of the 3rd Biomass Conference of the Americas, August 24-28, Montreal, Quebec. R.P. Overend and E. Chornet (eds). Elsevier Science, Inc. NewYork, New York.

Walsh, M.E. and D. Becker. 1996. "BIOCOST: A software program to estimate the cost of producing bioenergy crops". Pgs 480-486. Proceedings of Bioenergy '96-The Seventh National Bioenergy Conference, Sept. 15-19, Nashville, Tennessee. Southeastern Regional Biomass Energy Program, Muscle Shoals, AL.

Williams, J.R., C.A. Jones, J.R. Kinery and D.A. Spanel. 1989. The EPIC crop growth model. Trans. of the Amer. Soc. of Agric. Engineers, 32, 497-511.

Withrow-Robinson, B., D. Hibbs, and J. Beuter. 1995. Poplar chip production for the Willamette valley grass seed sites. Forest Research Laboratory, Oregon State University, Research Contribution 11.47 pgs. 


\section{INTERNAL DISTRIBUTION}

1. M. Brown

2-76. J. H. Cushman

77. D. E. Fowler

78. R. L. Graham

79. S. G. Hildebrand

80. G. K. Jacobs

81. P. Kanciruk

82. J. M. Loar

83. T. E. Myrick
84. D. E. Reichle

85. A. C. Schaffhauser

86. J. Sheffield

87. L. L. Wright

88. Central Research Library

89-91. ESD Library

92-93. Laboratory Records Dept.

94. Laboratory Records, ORNL-RC

\section{EXTERNAL DISTRIBUTION}

95. Phil Badger, TVA Environmental Research \& Services ,SE Regional Biomass Energy Program, P.O. Box 1010, Muscle Shoals, AL 35662-1010

96. M. Broido, Director, Environmental Sciences Division, ER-74, Department of Energy, 19901 Germantown Road, Germantown, MD 20874

97. Liu Chang, U. S. Department of Agriculture, Resource Econ. \& Social Sciences Div., P.O. Box 2890, Rm. 6162, USDA-S, Washington, DC 20013-2890

98. Ray Costello, U.S. Department. of Energy, Biomass Power Program, 1000 Independence Ave, SW, EE-13, Washington, DC 20585

99. E. G. Cumesty, ORNL Site Manager, Department of Energy, Oak Ridge National Laboratory, P.O. Box 2008, Oak Ridge, TN 37831-6269

100. B. English, University of Tennessee, Dept. Agricultural Economics, P. O. Box 1071, 302 Morgan Hall, Knoxville, TN 37901-1071

101. J. E. Ferrell, U.S. Department of Energy, Office of Fuels Development, 1000 Independence Avenue, EE-31, Washington, DC 20585

102. J. P. Giesy, Michigan State University, College of Natural Science, Department of Zoology, 203 Natural Science Building, East Lansing, MI 48824-1115

103. David Glassner, National Renewable Energy Laboratory, 1617 Cole Boulevard, Golden, CO 80401

104. Jeff Graef, Nebraska Energy Office, P.O. Box 95085, Lincoln, NE 60509-5085

105. Richard Handley, Northeast Regional Biomass Energy Program, 400 N. Capitol Street, NW, Suite 382, Washington, DC 20001

106. Jeff James, U.S. Department of Energy, Pacific Northwest \& Alaska Biomass Prog., 800 5th Avenue, Suite 3950, Seattle, WA 98104

107. Fred Kuzel, Great Lakes Regional Biomass Energy Program, Council of Great Lakes Governors, 35 E. Wacker Drive, Suite 1850, Chicago, IL 60601

108. Jacob Kaminsky, U.S. Department of Energy, Biomass Power Program, 1000 Independence Avenue, EE-13, Washington, DC 20585 
109. A. A. Lucier, National Council of the Paper Industry for Air and Stream Improvement, Inc., P.O. Box 13318, Research Triangle Park, NC 27709-3318

110. Richard Nelson, Kansas State University, Engineering Extension Programs, Ward Hall, Manhattan, KS 66506-2508

111. M. C. MacCracken, Director, Office of the U.S. Global Change Research Program, Code YS-1, 300 E Street, S.W., Washington, DC 20546

112. James Powell, U.S. Department of Energy, Atlanta Regional Support Office, 730 Peachtree Street, Suite 876, Atlanta, GA 30308-1212

113. L. Robinson, Director, Environmental Sciences Institute, Florida A\&M University Science Research Facility, 1520 S. Bronough Street, Tallahassee, FL 32307

114. Gerson Santos-Leon, U.S. Department of Energy, Office of Fuels Development, EE-31, Forrestal Bldg., 5G-086, Washington, DC 20585

115. Sarah Sprague, U.S. Department of Energy, Office of Fuels Development, EE 31, Forrestal Bldg., 5F-044, Washington DC 20585

116. J. M. Tiedje, 540 Plant and Soil Sciences Building, Michigan State University, East Lansing, MI 48824

117. Shaine Tyson, National Renewable Energy Laboratory, 1617 Cole Blvd., Golden CO, 80401-3393

118. Mike Voorhies, U.S. Department of Energy, Regional Biomass Program, 1000 Independence Ave, SW, EE-31, Washington, DC 20585

119. Dave Waltzman, Western Regional Biomass Energy Program, 1627 Cole Blvd., P.O. Box 3402, Golden, CO 80401

120. Art Wiselogel, National Renewable Energy Laboratory, 1617 Cole Blvd., Golden CO 80401

121-122. Office of Scientific and Technical Information, P.O. Box 62, Oak Ridge, TN 37831 